


\section{Indelingscategorieën broeikasgasemissie}

Voor SMK-bedrijven met bedekte teelt

Marc Ruijs ${ }^{1}$, Ruud van der Meer ${ }^{1}$, Peter Vermeulen ${ }^{2}$, Anton Kool ${ }^{3}$

1 Wageningen Economic Research

2 Peter Vermeulen Research, Consulting \& Coaching

3 Kool Analyse \& Advies

Dit onderzoek is uitgevoerd door Wageningen Economic Research in opdracht van SMK en gefinancierd door het ministerie van Landbouw, Natuur en Voedselkwaliteit.

Wageningen Economic Research

Wageningen, januari 2020

RAPPORT

2020-012

ISBN 978-94-6395-255-2 
Marc Ruijs, Ruud van der Meer, Peter Vermeulen, Anton Kool, 2020. Indelingscategorieën broeikasgasemissie; Voor SMK-bedrijven met bedekte teelt. Wageningen, Wageningen Economic Research, Rapport 2020-012. 46 blz.; 21 fig.; 6 tab.; 10 ref.

Wageningen Economic Research heeft in opdracht van Stichting Milieukeur (SMK) en gefinancierd door het Ministerie van Landbouw, Natuur en Voedselkwaliteit verschillende indelingssystemen onderzocht om SMK gecertificeerde bedrijven in de delen naar de omvang van de broeikasgasemissie. Er zijn vijf indelingen ontwikkeld, welke door SMK als basis kunnen worden gebruikt om bedrijven te stimuleren verder te verduurzamen op het terrein van energie. De keuze en uitwerking van het indelingssysteem is geen onderdeel van de studie.

Wageningen Economic Research has been commissioned by Stichting Milieukeur (SMK) and financed by the Ministry of Agriculture, Nature and Food Quality to investigate different classification systems for SMK certified companies according to the size of the greenhouse gas emissions. Five classification systems have been developed, which can be used by SMK as a basis for encouraging companies to become more sustainable in the field of energy. The choice and elaboration of the classification criterion is not part of the study.

Trefwoorden: glastuinbouw, broeikasgasemissie, indelingssystematiek van bedrijven

Dit rapport is gratis te downloaden op https://doi.org/10.18174/509820 of op www.wur.nl/economicresearch (onder Wageningen Economic Research publicaties).

(C) 2020 Wageningen Economic Research

Postbus 29703, 2502 LS Den Haag, T 07033583 30, E communications.ssg@wur.nl, www.wur.nl/economic-research. Wageningen Economic Research is onderdeel van Wageningen University \& Research.

\section{(cc) BY-NC}

Dit werk valt onder een Creative Commons Naamsvermelding-Niet Commercieel 4.0 Internationaallicentie.

(C) Wageningen Economic Research, onderdeel van Stichting Wageningen Research, 2020 De gebruiker mag het werk kopiëren, verspreiden en doorgeven en afgeleide werken maken. Materiaal van derden waarvan in het werk gebruik is gemaakt en waarop intellectuele eigendomsrechten berusten, mogen niet zonder voorafgaande toestemming van derden gebruikt worden. De gebruiker dient bij het werk de door de maker of de licentiegever aangegeven naam te vermelden, maar niet zodanig dat de indruk gewekt wordt dat zij daarmee instemmen met het werk van de gebruiker of het gebruik van het werk. De gebruiker mag het werk niet voor commerciële doeleinden gebruiken.

Wageningen Economic Research aanvaardt geen aansprakelijkheid voor eventuele schade voortvloeiend uit het gebruik van de resultaten van dit onderzoek of de toepassing van de adviezen.

Wageningen Economic Research is ISO 9001:2015 gecertificeerd.

Wageningen Economic Research Rapport 2020-012 | Projectcode 2282200517

Foto omslag: Marc Ruijs/Wageningen University \& Research 


\section{Inhoud}

$\begin{array}{ll}\text { Woord vooraf } & 5\end{array}$

$\begin{array}{ll}\text { Samenvatting } & 6\end{array}$

S.1 Handreikingen voor indeling van On the Way to PlanetProof-bedrijven ten aanzien van broeikasgasemissies $\quad 6$

$\begin{array}{lll}\text { S.2 Overige uitkomsten } & 7\end{array}$

$\begin{array}{ll}\text { S.3 Methode } & 7\end{array}$

$\begin{array}{ll}\text { Summary } & 8\end{array}$

S.1 Guidelines for classifying greenhouse horticulture operations in the 'On the Way to PlanetProof' certification scheme with regard to their greenhouse gas emissions $\quad 8$

S.2 Other outcomes $\quad 9$

S.3 Method 9

1

Inleiding

10

$1.1 \quad$ Aanleiding $\quad 10$

$\begin{array}{lll}1.2 & \text { Doelstelling } & 10\end{array}$

1.3 Afbakening $\quad 11$

1.4 Leeswijzer $\quad 11$

2

$\begin{array}{ll}\text { Methode } & 12\end{array}$

2.1 SMK-rekentool voor broeikasgasemissies 12

2.2 Informatienetcijfers als basis voor indelingssystemen $\quad 12$

$\begin{array}{ll}\text { Resultaten } & 15\end{array}$

$\begin{array}{lll}3.1 & \text { Inleiding } & 15\end{array}$

3.2 Variatie in energieverbruik en $\mathrm{CO}_{2}$-emissie en invloedfactoren 15

3.2.1 Totale $\mathrm{CO}_{2}$-emissie $\quad 15$

3.2.2 Totale $\mathrm{CO}_{2}$-emissie per gewas 16

3.2.3 Totale $\mathrm{CO}_{2}$-emissie en energieverbruik 16

3.2.4 Totale $\mathrm{CO}_{2}$-emissie en netto-energieverbruik 18

3.2.5 Totale $\mathrm{CO}_{2}$-emissie en belichting 20

3.2.6 Totale $\mathrm{CO}_{2}$-emissie en zelf opwekken van elektriciteit met een wkk 21

3.2.7 Totale $\mathrm{CO}_{2}$-emissie en aantal schermen 22

3.2.8 Totale $\mathrm{CO}_{2}$-emissie en leeftijd kassen 22

3.2.9 Totale $\mathrm{CO}_{2}$-emissie en haar bestanddelen 23

3.2.10 Regressieanalyse totale $\mathrm{CO}_{2}$-emissie en invloedfactoren 24

3.2.11 Vergelijking bepalingsmethoden broeikasgasemissies 28

3.3 Indelingscategorieën voor broeikasgasemissies 30

3.4 Additionele monitoring van data op de On the Way to PlanetProof-bedrijven voor de indelingscategorieën 36

$\begin{array}{lll}4.1 & \text { Discussie } & 37\end{array}$

4.2 Aanbevelingen $\quad 39$

$\begin{array}{ll}\text { Literatuur en websites } & 40\end{array}$ 
Bijlage 1 Toelichting en achtergrond rekenmodule voor broeikasgasemissie (c)

Bijlage 2 Toelichting verschillende methodieken om de broeikasgasemissie op glastuinbouwbedrijven te kwantificeren

Bijlage $3 \mathrm{CO}_{2}$-emissie ( $\mathrm{kg} \mathrm{CO}$-equivalenten per $\mathrm{m}^{2}$ per jaar) en haar bestanddelen per bedrijf in 2015 en 2016 


\section{Woord vooraf}

Stichting Milieukeur (SMK) wil haar gecertificeerde deelnemers met bedekte teelt stimuleren om verder te verduurzamen op het terrein van energie. Met haar rekentool voor broeikasgasemissie wordt per bedrijf de broeikasgasemissie (kortweg ' $\mathrm{CO}_{2}$-emissie') bepaald op basis van het nettoenergieverbruik voor met name verwarming, koeling en belichting. SMK streeft ernaar de $\mathrm{CO}_{2}$-emissie als instrument te gebruiken om gecertificeerde SMK-bedrijven met bedekte teelt te bewegen op fossiele energie te besparen en over te stappen op hernieuwbare energie. De vraag is alleen op welke wijze de bedrijven met bedekte teelt zijn in te delen, om enerzijds verduurzaming bij deze bedrijven te stimuleren en anderzijds rekening te houden met de context waarin bedrijven zich bevinden.

SMK heeft Wageningen Economic Research gevraagd deze studie uit te voeren op basis van haar Bedrijveninformatienet met uitgebreide economische en technische informatie van de bedrijven met bedekte teelt. Daarbij beschikt Wageningen Economic Research over meer bedrijven met bedekte teelt in haar steekproefnet dan SMK. SMK heeft het ministerie van Landbouw, Natuur en Voedselkwaliteit (LNV) bereid gevonden om de studie van Wageningen Economic Research te financieren uit het Programma 'Kas als Energiebron'.

De studie is uitgevoerd door Marc Ruijs (projectleider) en Ruud van der Meer van Wageningen Economic Research. Voor het analyseren van de data in het Informatienet is samengewerkt met Peter Vermeulen van Peter Vermeulen Research, Consulting \& Coaching (voorheen werkzaam bij Wageningen Plant Research, BU Glastuinbouw) en met Anton Kool van Kool Analyse \& Advies (ontwikkelaar SMK-rekenmodule voor broeikasgasemissie). Het project is vanuit SMK begeleid door Jantineke Hofland-Zijlstra, Jaap Bij de Vaate en Herman Docters van Leeuwen.

Dank gaat uit naar de leden van de SMK Themawerkgroep Energie voor hun bijdrage aan de totstandkoming van dit rapport.

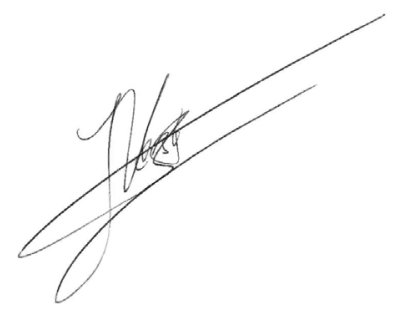

Prof.dr.ir. J.G.A.J. (Jack) van der Vorst

Algemeen Directeur Social Sciences Group (SSG)

Wageningen University \& Research 


\section{Samenvatting}

\section{S.1 Handreikingen voor indeling van On the Way to PlanetProof-bedrijven ten aanzien van broeikasgasemissies}

Stichting Milieu Keur (SMK) wil de bedrijven die gecertificeerd zijn in het programma On the Way to PlanetProof stimuleren om broeikasgasemissies verder te verminderen en daartoe normen voor broeikasgasemissie (uitgedrukt in $\mathrm{CO}_{2}$-equivalenten) opleggen op basis van het energieverbruik en de teelt- en/of bedrijfskenmerken die de omvang van het energieverbruik bepalen. Daarbij wil SMK een indeling van bedrijven in categorieën gebruiken naar de omvang van de $\mathrm{CO}_{2}$-emissie van een bedrijf zodat normen worden gedifferentieerd.

Doel van dit onderzoek is om op basis van het Bedrijven-Informatienet, dat meer gegevens over energieverbruik en energie gerelateerde bedrijfs- en/of teeltkenmerken heeft dan de SMK-database, indelingen te ontwerpen om bedrijven met bedekte teelt in te delen in categorieën. De voorstellen voor zo' $n$ indelingssysteem moeten het voor SMK eenvoudiger maken om bedrijven in te delen naar het niveau van de broeikasgasemissie op basis van energieverbruik en daarmee samenhangende teelt- en/of bedrijfskenmerken. Daarnaast dient de studie inzicht te geven in bedrijfs- en/of teeltkenmerken en maatregelen die de variatie in energieverbruik verklaren en daarmee handelingsperspectieven voor reductie kunnen bieden voor de On the Way to PlanetProof-bedrijven.

Er zijn vijf alternatieve indelingen opgesteld om On the Way to PlanetProof-bedrijven in de glastuinbouw in te delen naar de omvang van de broeikasgasemissie met het doel deze bedrijven te stimuleren verder te verduurzamen op het terrein van energie. De vijf indelingssystematieken zijn:

1. Indeling in qua omvang vaste grootteklassen voor broeikasgasemissie (in $\mathrm{kg} \mathrm{CO}_{2}$-equivalenten per $\mathrm{m}^{2}$ ). Bijvoorbeeld: 0-50, 50-100, etc.

2. Indeling in klassen op basis van kwartielen of kwintielen met geschatte onder- en bovengrenswaarden (in $\mathrm{kg} \mathrm{CO}_{2}$-equivalenten per $\mathrm{m}^{2}$ ). De grenswaarden zijn bepaald op basis van gelijke aantallen bedrijven in de verschillende (vier of vijf) klassen.

3. Indeling in klassen op basis van kwartielen en de onderliggende bestanddelen van de broeikasgasemissie met onder- en bovengrenswaarden (in $\mathrm{kg} \mathrm{CO}_{2}$-equivalenten per $\mathrm{m}^{2}$ ).

4. Indeling op basis van de vastgestelde regressievergelijking voor de broeikasgasemissie, waarbij $>50 \%$ van de bedrijven aan de minimale eis moet voldoen (omvang broeikasgasemissie bij de mediaan) en een vrijstelling wordt verleend aan de $25 \%$ On the Way PlanetProof-bedrijven met de laagste broeikasgasemissie (in $\mathrm{kg} \mathrm{CO}_{2}$-equivalenten per $\mathrm{m}^{2}$ ).

5. Uniforme prestatie-eis voor alle On the Way to PlanetProof-bedrijven van bijvoorbeeld $2 \%$ emissiereductie per jaar of een veelvoud van $2 \%$ emissiereductie in een $x$ aantal jaar.

De daadwerkelijke grenswaarden voor broeikasgasemissie voor de indelingen onder 1 tot en met 4 zullen moeten worden bepaald op basis van de energiedata van On the Way to PlanetProof-bedrijven. Deze activiteit dient na keuze uit een van de bovengenoemde vier indelingen te worden uitgevoerd. Indeling vijf (uniforme prestatie-eis) is de eenvoudigste indeling, waarbij alle On the Way to PlanetProof-bedrijven worden gestimuleerd om te verduurzamen op energiegebied. De absolute omvang van de emissiereductie is afhankelijk van de uitgangssituatie en is groter naarmate het (fossiele) energieverbruik hoger is. Bedrijven die in het verleden veel energie hebben bespaard en daarmee hun broeikasgasmissie hebben gereduceerd, hoeven dus minder inspanningen te doen. Deze 
methode heeft bovendien als voordeel dat eenvoudiger rekening te houden is met het investeringsritme van de bedrijven.

De indelingswijze van bedrijven zoals door SMK zelf voorgesteld, waarbij de broeikasgasemissie wordt bepaald op basis van het energieverbruik voor verwarming en belichting, stuit op uitvoeringsbezwaren, omdat hiervoor aanvullende data moeten worden verzameld die niet in afdoende mate controleerbaar zijn.

\section{S.2 Overige uitkomsten}

De omvang van de broeikasgasemissie wordt in significante mate verklaard door het nettoenergieverbruik. Dit is het saldo van input van (fossiele) energie en output van energie (met name de door de wkk geproduceerde elektriciteit die is weggeleverd aan het net of aan derden).

De meeste energie wordt - zoals verwacht - verbruikt voor het proces van verwarming en belichting op de bedrijven.

De leeftijd van de kassen en het aantal (energie)schermen geven geen goede verklaring voor de broeikasgasemissie. Zoals te verwachten valt, hebben de mate van belichten en de aanwezigheid en grootte van de wkk-installatie een significante invloed op de omvang van de broeikasemissie.

De omvang van de broeikasgasemissie verschilt niet alleen tussen gewassen, maar ook sterk binnen de gewassen. Dit hangt duidelijk samen met de wijze waarop in de energievraag wordt voorzien op het betreffende bedrijf.

\section{S.3 Methode}

In opdracht van Stichting Milieukeur en gefinancierd door het ministerie van Landbouw, Natuur en Voedselkwaliteit heeft Wageningen Economic Research in samenwerking met de bedrijven Vermeulen, Research, Consultancy \& Coaching en Kool Analyse \& Advies de emissie van broeikasgassen op glastuinbouwbedrijven geanalyseerd. De omvang van de broeikasgasemissie is bepaald op basis van de energiedata in het Bedrijveninformatienet van Wageningen Economic Research en berekend met de rekentool voor broeikasgasemissie volgens de zogenaamde attributiemethode. Hiervoor zijn de energiedata van de jaren 2015 tot en met 2017 gebruikt. 


\section{Summary}

\section{S.1 Guidelines for classifying greenhouse horticulture operations in the 'On the Way to PlanetProof' certification scheme with regard to their greenhouse gas emissions}

Stichting Milieu Keur (SMK) wants to encourage greenhouse horticulture operations that are certified as part of the On the Way to PlanetProof scheme to further reduce their greenhouse gas emissions. To that end we have set standards for greenhouse gas emissions (expressed in $\mathrm{CO}_{2}$ equivalents) based on energy consumption, crop characteristics and/or operational characteristics that determine the magnitude of energy consumption. In addition, SMK wants to classify greenhouse horticulture operations into categories based on the magnitude of their $\mathrm{CO}_{2}$ emissions. This ensures that the standards are differentiated.

The aim of this study is to design a classification system for greenhouse horticulture operations based on the Farm Accountancy Data Network, which has more data on energy consumption and energyrelated operational and/or crop characteristics than the SMK database. The proposals for such a classification system should make it easier for SMK to classify greenhouse horticulture operations according to the level of greenhouse gas emissions based on energy consumption and the corresponding crop and/or operational characteristics. In addition, the study should provide insight into operational and/or crop characteristics and measures that explain the variation in energy consumption, and can therefore offer action perspectives for emission reduction for the greenhouse horticulture operations participating in the On the Way to PlanetProof certification scheme.

Five alternative classification methods have been established to classify greenhouse horticulture operations in the On the Way to PlanetProof scheme according to the magnitude of their greenhouse gas emissions. The aim is to incentivise these operations to use energy more sustainably. The five classification methods are the following:

1. Classification according to fixed magnitude classes for greenhouse gas emissions (in $\mathrm{kg} \mathrm{CO}_{2}$ equivalents per $\mathrm{m}^{2}$ ). For example: $0-50 \mathrm{~kg} \mathrm{CO}$-eq $/ \mathrm{m}^{2}, 50-100 \mathrm{~kg} \mathrm{CO}$-eq/ $\mathrm{m}^{2}$, etc.

2. Classification into quartile or quintile classes with estimated lower and upper limit values (in $\mathrm{kg}$ $\mathrm{CO}_{2}-\mathrm{eq} / \mathrm{m}^{2}$ ). The limit values are determined on the basis of equal numbers of greenhouse horticulture operations in the classes (four or five classes).

3. Classification into quartile-based classes and the underlying components of greenhouse gas emissions with lower and upper limit values (in $\mathrm{kg} \mathrm{CO}-\mathrm{eq} / \mathrm{m}^{2}$ ).

4. Classification based on the established regression equation for the greenhouse gas emissions of greenhouse horticulture operations participating in the On the Way to PlanetProof scheme, where $>50 \%$ of the operations must meet the minimum requirement (greenhouse gas emissions at the median) and an exemption is granted to the $25 \%$ participating operations with the lowest greenhouse gas emissions (in $\mathrm{kg} \mathrm{CO}_{2}-\mathrm{eq} / \mathrm{m}^{2}$ ).

5. A uniform performance requirement for all greenhouse horticulture operations participating in the On the Way to PlanetProof scheme of for example with $2 \%$ or a multiple of $2 \%$ emission reduction during $\mathrm{x}$ number of years. 
The actual limit values for greenhouse gas emissions regarding classifications 1 through 4 will have to be determined based on the energy data of greenhouse horticulture operations participating in the On the Way to PlanetProof scheme. This determination must be performed after choosing one of the above four classifications.

Classification 5 (uniform performance requirement) is the simplest classification, whereby all greenhouse horticulture operations participating in the On the Way to PlanetProof scheme are incentivised to become more sustainable regarding energy. The absolute magnitude of the emission reduction depends on the initial situation; the required reduction is higher if the initial energy/fossil energy consumption is higher. Greenhouse horticulture operations that have saved energy in the past, and have thereby substantially reduced their greenhouse gas emissions, therefore have to make fewer reductions than less energy-efficient operations. Another advantage of this method is that it is simpler to take the investment tempo of the greenhouse horticulture operations into account.

The classification method of greenhouse horticulture operations as proposed by SMK itself, in which greenhouse gas emissions are determined on the basis of the energy consumption for heating and lighting, will probably be difficult to implement because this requires the collection of additional data that cannot be adequately monitored and verified.

\section{S.2 Other outcomes}

The magnitude of the greenhouse gas emissions can be explained to a significant extent by the net energy consumption. This is the balance of input from energy/fossil energy and output of energy (in particular the electricity produced by cogeneration of heat and power - CHP - that has been delivered to the grid or to third parties). As expected, most of the energy is used for heating and lighting at the greenhouse horticulture operations.

The age of the greenhouses and the number of energy screens do not provide a good indication for the greenhouse gas emissions. Predictably, the intensity of lighting and the presence and size of the CHP installation have a significant influence on the magnitude of the greenhouse gas emissions.

The magnitude of greenhouse gas emissions varies not only between different crops, but also varies greatly between the same crops grown at different operations. This is clearly related to the way in which the energy demand is supplied at the relevant operation.

\section{S.3 Method}

Commissioned by Stichting Milieukeur (SMK) and funded by the Ministry of Agriculture, Nature and Food Quality, Wageningen Economic Research - in collaboration with Vermeulen Research, Consultancy \& Coaching and Kool Analyse \& Advies - analysed the emissions of greenhouse gases at greenhouse horticulture operations. The magnitude of the greenhouse gas emissions is determined on the basis of the energy data in the Farm Accountancy Data Network of Wageningen Economic Research using the SMK calculation tool for greenhouse gas emissions according to the 'allocation method'. Energy data from the years 2015 through 2017 were used for this purpose. 


\section{$1 \quad$ Inleiding}

\section{$1.1 \quad$ Aanleiding}

Het certificatieschema 'On the Way to PlanetProof' van Stichting Milieukeur (SMK) is ontwikkeld om het fossiele-energieverbruik zoveel mogelijk te beperken en het gebruik van duurzame energie te stimuleren. SMK (College van Deskundigen) wil de emissie van broeikasgassen gaan beperken op basis van een absoluut normeringssysteem. Oogmerk hierbij is om bedrijven te prikkelen om het fossiele-energieverbruik verder te verlagen. Het normeringssysteem moet bedrijven met bedekte teelt handelingsperspectief bieden om het bedrijf verder te verduurzamen.

Op dit moment wordt de hoeveelheid broeikasgasemissie op bedekteteeltbedrijven met het On the Way to PlanetProof-milieucertificaat berekend met de voor SMK ontwikkelde rekenmodule voor broeikasgasemissie, die keurmerkhouders sinds 1 januari 2018 verplicht zijn in te vullen. Er zijn nu circa 150 keurmerkhouders, waarvan het grootste deel vruchtgroentebedrijven. In de rekenmodule worden twee methodes gebruikt voor het berekenen van de broeikasgasemissie, uitgedrukt in $\mathrm{CO}_{2}-$ equivalenten per $\mathrm{m}^{2}$ : de attributiemethode en de substitutiemethode.

SMK heeft Wageningen Economic Research gevraagd om een of meer indelingssystemen voor SMKbedrijven met bedekte teelt op te stellen, waarmee deze bedrijven zijn in te delen naar de berekende $\mathrm{CO}_{2}$-emissie op basis van het energieverbruik (t.b.v. verwarming, koeling, $\mathrm{CO}_{2}$-dosering en belichting) en de verbruiksbepalende teelt- en bedrijfskenmerken. Uit deze voorgestelde indelingssystemen zal SMK er één kiezen dat als basis wordt genomen voor het rangschikken van On the Way to PlanetProof-bedrijven naar de omvang van de broeikasgasemissie, waarvan SMK verwacht dat daar een stimulering vanuit gaat om verder te verduurzamen op energiegebied.

\subsection{Doelstelling}

Het doel van het onderzoek is systemen of indelingen te ontwerpen om gecertificeerde On the Way to PlanetProof-bedrijven met bedekte teelt in te delen in categorieën als basis voor het vaststellen van normen voor broeikasgasemissie (uitgedrukt in $\mathrm{CO}_{2}$-equivalenten). De indeling(en) word(t)(en) bepaald op basis van het energieverbruik (voor verwarming, koeling, $\mathrm{CO}_{2}$-dosering en belichting) en de teelt- of bedrijfskenmerken die de omvang van het energieverbruik bepalen. Daarnaast dient de studie inzicht te geven in bedrijfs- en/of teeltkenmerken en maatregelen die de variatie in energieverbruik verklaren en daarmee handelingsperspectieven voor reductie kunnen bieden voor de On the Way to PlanetProof-bedrijven.

De voorstellen voor een indelingssysteem moeten het eenvoudiger maken om bedrijven in te delen naar het niveau van de broeikasgasemissie, waardoor On the Way to PlanetProof-bedrijven worden gestimuleerd om verder te verduurzamen op het terrein van energie en de broeikasgasemissie te reduceren.

Het onderzoek wordt gefinancierd door het ministerie van Landbouw, Natuur en Voedselkwaliteit (LNV) binnen het kader van het Programma 'Kas als Energiebron' van de overheid en de brancheorganisatie Glastuinbouw Nederland. 


\subsection{Afbakening}

Het bepalen van absolute normen voor broeikasgasemissies, zoals deze worden opgenomen in het certificatieschema van On the Way to PlanetProof op basis van de indelingsclassificatie(s) die in dit rapport worden voorgesteld, valt buiten deze opdracht. Projectmedewerkers van SMK zullen op basis van dit rapport en het advies vanuit de begeleidingscommissie Energie \& Klimaat een voorstel voorleggen aan het College van Deskundigen van SMK, zodat hierover een afgewogen besluit kan worden genomen.

\subsection{Leeswijzer}

Hoofdstuk 2 gaat in op de methode en aanpak van de studie. In hoofdstuk 3 worden de verklarende factoren voor de variatie in energieverbruik en $\mathrm{CO}_{2}$-emissie beschreven, evenals verschillende ontwerpen van indelingssystemen voor broeikasgasemissies. Hoofdstuk 4 bevat de discussie en aanbevelingen van mogelijke indelingssystemen voor gecertificeerde On the Way to PlanetProofbedrijven met bedekte teelt als basis voor de door SMK op te stellen normen voor broeikasgasemissie. 


\section{$2 \quad$ Methode}

\section{$2.1 \quad$ SMK-rekentool voor broeikasgasemissies}

In de studie is uitgegaan van de rekenmodule voor broeikasgasemissie ${ }^{1}$, die door het bedrijf Kool Analyse \& Advies is ontwikkeld voor SMK. In de rekentool wordt de emissie van broeikasgassen berekend op basis van het energieverbruik van het individuele On the Way to PlanetProof-bedrijf. Hierbij worden de broeikasgassen $\mathrm{CO}_{2}$ en $\mathrm{CH}_{4}$ (methaan, dat vrijkomt in het zogenaamde methaanslip van wkk-installaties) omgerekend naar $\mathrm{CO}_{2}$-equivalenten $\left(\mathrm{CO}_{2}\right.$-eq.). Alle inputstromen van warmte (gas) en elektriciteit (inkoop en zelfopwekking) zijn daarin meegenomen. Met betrekking tot de outputstromen $\left(\mathrm{CO}_{2}\right.$, elektriciteit en/of warmte) zijn in de rekentool twee rekenwijzen aanwezig, de zogenaamde attributiemethode en de substitutiemethode. Bij de attributiemethode wordt de omvang van de input- en outputstromen bepaald op basis van de energie-inhoud en vervolgens de inherente broeikasgasemissie berekend. Bij de substitutiemethode wordt de omvang van de input op dezelfde wijze bepaald als bij de attributiemethode, maar wordt de output bepaald op basis van het vermeden elektriciteits- en/of warmteverbruik en de daaraan gekoppelde broeikasgasemissie.

In overleg met de opdrachtgever (SMK) en financier (LNV) is in deze studie besloten om voor het ontwerpen van indelingscategorieën de attributiemethode als vertrekpunt te nemen. De substitutiemethode is nog onderwerp van overleg ${ }^{2}$ en is buiten de scope van deze studie gehouden. In bijlage 1 is nader toegelicht hoe de broeikasgasemissie in de rekenmodule wordt berekend.

In deze studie zijn met betrekking tot de $\mathrm{CO}_{2}$-huishouding alle inputstromen (via ketel, wkk en extern) in beeld gebracht (het raamwerk) en is op basis daarvan de omvang van de $\mathrm{CO}_{2}$-emissie (output) bepaald. Hiermee worden in beginsel de inputstromen van energie en $\mathrm{CO}_{2}$ op identieke wijze vastgesteld. Ingekocht $\mathrm{CO}_{2}$ (fossiel en duurzaam) is kortcyclisch (komt na opname door het gewas op korte termijn weer vrij) en zou meegenomen kunnen worden in de omvang van de $\mathrm{CO}_{2}$-emissie. Aangekocht $\mathrm{CO}_{2}$ is echter geen onderdeel van de huidige rekenmodule voor broeikasgasemissie. Daarover is binnen SMK nog geen besluit genomen. ${ }^{3}$ Hierdoor is de aan aangekocht $\mathrm{CO}_{2}$ gerelateerde $\mathrm{CO}_{2}$-emissie niet meegenomen in de totale $\mathrm{CO}_{2}$-emissie (emissiefactor van aangekocht $\mathrm{CO}_{2}$ is op nul gesteld).

De opname van $\mathrm{CO}_{2}$ door het gewas is beperkt en ligt in de orde van 4-9\% van het totaal aangeboden $\mathrm{CO}_{2}$ uit gas en aangekocht $\mathrm{CO}_{2}$ (vloeibaar en gasvormig) (P. Vermeulen, 2019). Daarbij komt dat het door het gewas opgenomen $\mathrm{CO}_{2}$ op korte termijn ook weer vrijkomt, omdat het gewas vergaat of wordt geconsumeerd.

Ten overvloede dient te worden opgemerkt dat er in de huidige berekening van $\mathrm{CO}_{2}$ binnen de SMK rekenmodule voor broeikasgasemissie nog geen $\mathrm{CO}_{2}$-emissie doorberekend wordt bij dosering van aangekocht $\mathrm{CO}_{2}$. Dit wordt als $\mathrm{CO}_{2}$-neutraal beschouwd omdat het $\mathrm{CO}_{2}$ betreft dat als restproduct van de industrie wordt afgenomen.

\subsection{Informatienetcijfers als basis voor indelingssystemen}

In de studie is het Bedrijveninformatienet van Wageningen Economic Research gebruikt als vertrekpunt om de variatie in het energieverbruik op bedrijfsniveau vast te stellen en om tot indelingscategorieën voor SMK-bedrijven te komen met betrekking tot de omvang van de $\mathrm{CO}_{2}$-emissie.

\footnotetext{
1 De rekenmodule voor broeikasgasemissie van SMK was geen onderwerp van studie en is als vertrekpunt genomen in het onderzoek.

2 De substitutiemethode is feitelijk een bepaalde allocatiewijze in het geval van coproductie en is onderwerp van studie in de PPS HortiFootPrint, die door Wageningen Economic Research wordt uitgevoerd.

3 Het besluit om de inkoop van $\mathrm{CO}_{2}$ op te nemen in de SMK-rekentool voor broeikasgasemissie moet nog worden genomen door het College van Deskundigen van SMK.
} 
Het Bedrijveninformatienet omvat circa 260 glastuinbouwbedrijven, zowel vruchtgroente- als sierteeltbedrijven, met minimaal $2.500 \mathrm{~m}^{2}$ aan kasoppervlak. Ook begaanbare (rechtop lopend) folieof tunnelkassen behoren hiertoe. Van deze Informatienetbedrijven zijn niet alleen het energieverbruik (gas, elektriciteit, olie, hout, warmte etc.) en de inkoop van $\mathrm{CO}_{2}$ bekend, maar ook de uitrusting ten aanzien van energieopwekking, energieopslag, verwarming en belichting, energiebesparende technieken en energielevering aan derden. Daarnaast is bekend welke gewassen ze telen en hoeveel ze produceren. Op basis van die data kunnen de bedrijven worden ingedeeld naar de omvang van de $\mathrm{CO}_{2}$-emissie en kunnen relaties worden gelegd met de teelt- en bedrijfskenmerken. De verschillende energievariabelen in het Bedrijveninformatienet zijn in onderstaand overzicht opgenomen.

Het energieverbruik en de inherente $\mathrm{CO}_{2}$-emissie zijn in kaart gebracht voor drie kalenderjaren: 2015, 2016 en 2017. De gegevens voor 2018 waren nog niet beschikbaar ten tijde van deze studie. De verschillende jaren zijn meegenomen om invloeden van het buitenklimaat op energieverbruik en $\mathrm{CO}_{2}$ emissie na te gaan. Omdat de drie jaren qua buitenklimaat niet veel van elkaar verschilden, zijn de drie jaren bij elkaar genomen, zodat een groter aantal waarnemingen $(n=854)$ beschikbaar was voor analyse.

Overzicht beschikbare energiegerelateerde variabelen of parameters in het Informatienet voor bedrijven met bedekte teelt

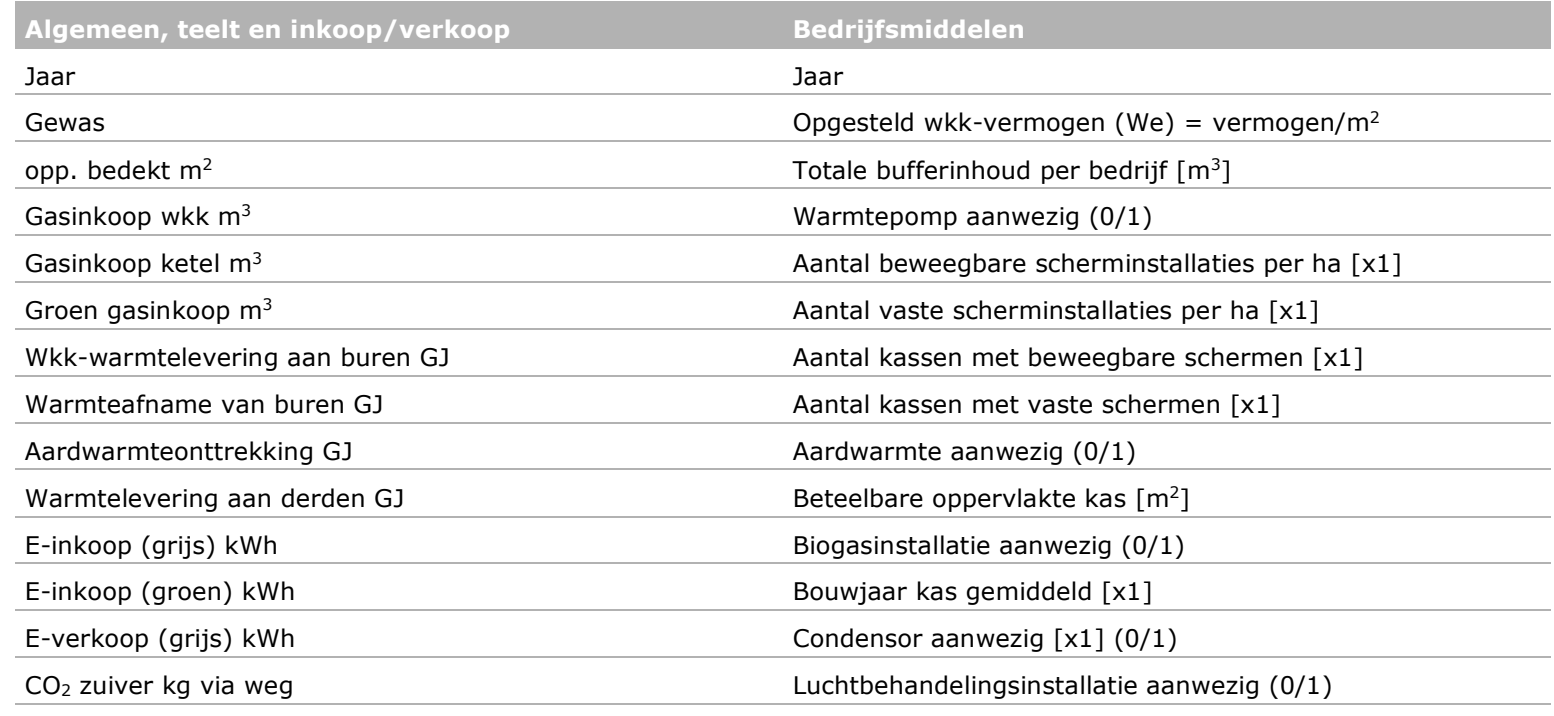

Rookgas $\mathrm{CO}_{2} \mathrm{~kg}$ via RoCa3 via buis

OCAP $\mathrm{CO}_{2} \mathrm{~kg}$ zuiver via buis

In 2015, 2016 en 2017 was de buitentemperatuur uitgedrukt in graaddagen 2.686, 2.785 respectievelijk 2.747 en de lichtsom (in \% van een normaal jaar; $100 \%=35010^{3} \mathrm{~J} / \mathrm{cm}^{2}$ ) 111,108 respectievelijk 106 (Van der Velden en Smit, 2018). De verschillen in buitentemperatuur (3,7\%) en in lichtsom $(4,7 \%)$ tussen de jaren zijn niet groot en daarmee nauwelijks van invloed op het energieverbruik en de $\mathrm{CO}_{2}$-emissie.

Om de resultaten van de studie beter te interpreteren is hierna nog aanvullende informatie opgenomen over de dataset van het Bedrijveninformatienet van Wageningen Economic Research in vergelijking met die van SMK. 
Overzicht relevante variabelen en indicatoren in het Bedrijveninformatienet van Wageningen Economic Research en van SMK voor bedrijven met bedekte teelt

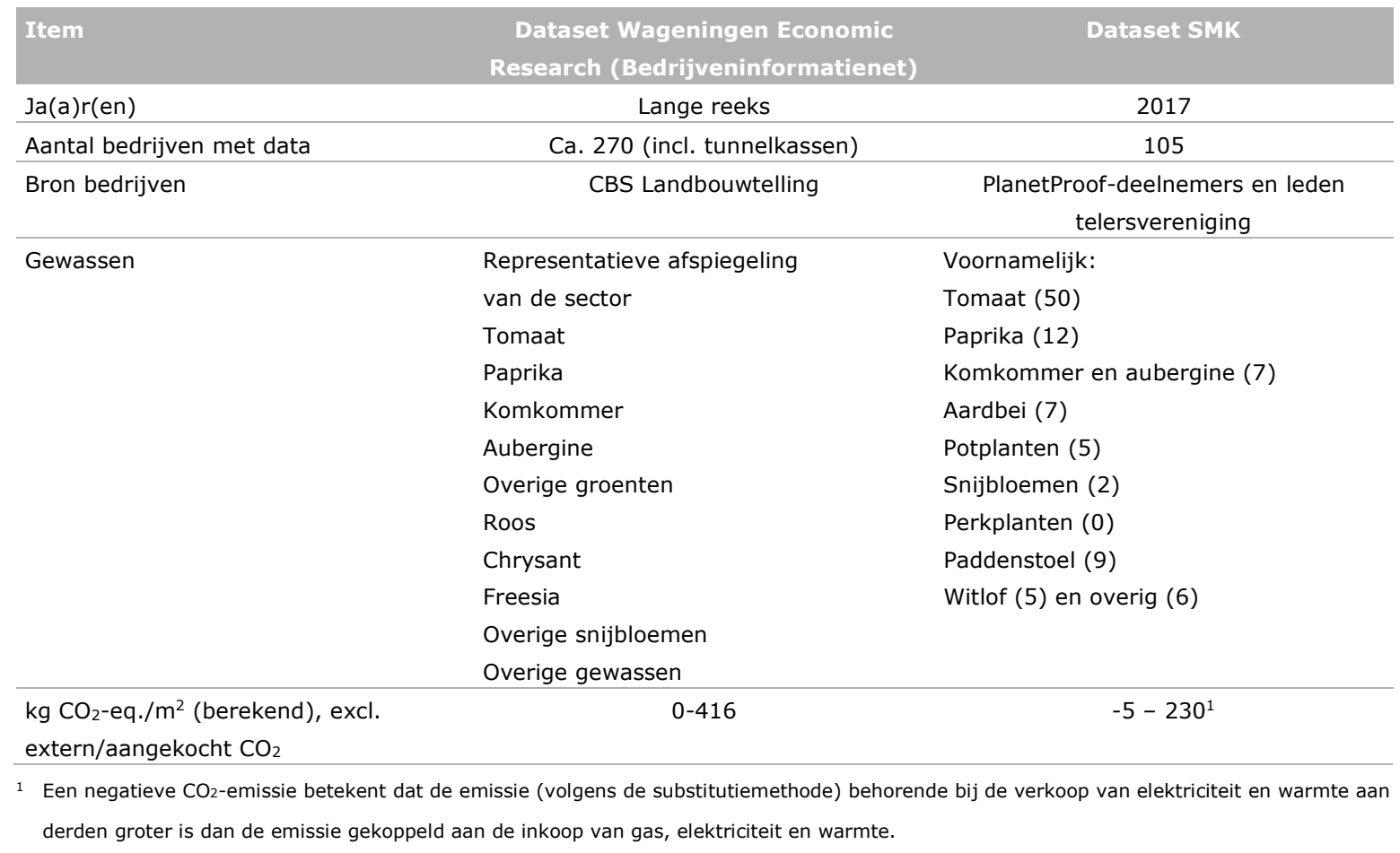

Voor het koppelen van bedrijfsdata uit het Informatie aan de rekenmodule voor broeikasgasemissie heeft Kool Analyse \& Advies het bestaande invoerformulier aangepast, zodat direct ook de $\mathrm{CO}_{2}$-emissie wordt berekend volgens de attributiemethode (en substitutiemethode).

Met de Informatienetdata zijn grafieken en tabellen opgesteld van het energieverbruik en de berekende $\mathrm{CO}_{2}$-emissie om inzicht te geven in de variatie van de $\mathrm{CO}_{2}$-emissie en de invloedfactoren die deze variatie (met name) bepalen.

Voor de statistische verwerking van gegevens is het softwarepakket SPSS gebruikt om regressievergelijkingen en correlaties te bepalen tussen enerzijds de broeikasgasemissie en anderzijds het energieverbruik (gas, elektra, warmte) en de variabelen die daarop van invloed zijn, zoals belichting, wkk-installatie, (energie)schermen, leeftijd kassen (gebouwd voor en vanaf 2000) en gewassoort. Op basis van de regressievergelijkingen is vastgesteld welke variabelen de variatie in $\mathrm{CO}_{2}$-emissie bepalen op de bedrijven met bedekte teelt.

De voorgestelde indelingscategorieën voor de On the Way to PlanetProof-bedrijven zijn voorzien van opmerkingen. Daarnaast zijn aanbevelingen gedaan voor de rekenmodule voor broeikasgasemissie en voor het aanvullend monitoren van data door de On the Way to PlanetProof-bedrijven om de omvang van de $\mathrm{CO}_{2}$-emissie te kunnen bepalen.

In deze studie zijn voorstellen voor indelingscategorieën ontworpen om On the Way to PlanetProofbedrijven in te delen naar de omvang van de $\mathrm{CO}_{2}$-emissie of andere indicatoren die samenhangen met de $\mathrm{CO}_{2}$-emissie. Ook is een regressieanalyse op het datamateriaal uitgevoerd om te bekijken of deze insteek een indelingscategorie kan opleveren. Wageningen Economic Research stelt geen normen op voor de indeling van On the Way to PlanetProof-bedrijven op basis van $\mathrm{CO}_{2}$-emissie. Dit wordt door SMK zelf uitgevoerd.

Ter verduidelijking van en inzicht in de omvang van de $\mathrm{CO}_{2}$-emissie is naast de $\mathrm{CO}_{2}$-emissie volgens de attributiemethode ook die volgens de substitutiemethode en de IPCC-methode bepaald en opgenomen in deze rapportage. Voor een toelichting op de verschillen in uitgangspunten en bepalingswijze tussen de drie methoden wordt verwezen naar bijlage 2. De gehanteerde emissiefactoren voor broeikasgassen verschillen deels per bepalingsmethode (Kool, 2019). 


\section{Resultaten}

\subsection{Inleiding}

Het Bedrijveninformatienet van Wageningen Economic Research is de basis geweest voor informatie over het energieaspect op bedrijven met bedekte teelt. Dit betreft data over het energie- en het $\mathrm{CO}_{2}-$ verbruik en over de energiegerelateerde teelt- en bedrijfskenmerken.

Hierna is in eerste instantie de variatie in netto-energieverbruik en $\mathrm{CO}_{2}$-emissie weergegeven in afhankelijkheid van de invloedfactoren. Dit is grafisch weergegeven om het inzicht in de variatie te vergroten. $\mathrm{Er}$ is tevens een regressieanalyse uitgevoerd om significante verbanden tussen de omvang van de $\mathrm{CO}_{2}$-emissie en de verklarende factoren te bepalen.

Op basis van de inzichten in de variatie van het energieverbruik en de $\mathrm{CO}_{2}$-emissie en in de meest bepalende invloedfactoren zijn meerdere indelingscategorieën opgesteld om On the Way to PlanetProof-bedrijven in te delen en hen handelingsperspectieven te bieden om verder te verduurzamen.

\subsection{Variatie in energieverbruik en $\mathrm{CO}_{2}$-emissie en invloedfactoren}

\subsubsection{Totale $\mathrm{CO}_{2}$-emissie}

De totale $\mathrm{CO}_{2}$-emissie op de Informatienetbedrijven met bedekte teelt (inclusief tunnels) is weergegeven in figuur 3.1. De omvang van de totale berekende $\mathrm{CO}_{2}$-emissie varieert van bijna nul (0) tot $416 \mathrm{~kg} \mathrm{CO}$-equivalenten per $\mathrm{m}^{2}$.

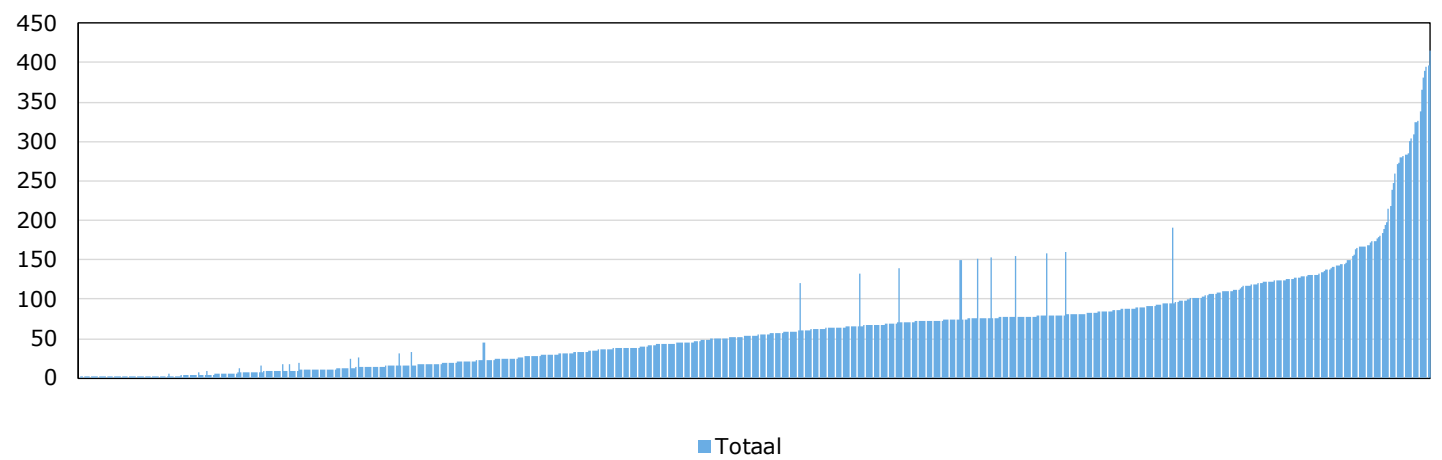

Figuur 3.1 $\mathrm{CO}_{2}$-emissie ( $\mathrm{kg} \mathrm{CO} 2$-eq. per $\mathrm{m}^{2}$ per jaar) van bedrijven in de periode 2015-2017, gerangschikt naar de hoogte van de emissie

De meeste bedrijven (ruim 80\%) blijven onder de $100 \mathrm{~kg} \mathrm{CO}$-equivalenten per $\mathrm{m}^{2}$. De overige 20\% veroorzaakt een hogere emissie per $\mathrm{m}^{2}$. Deze laatste groep bedrijven teelt zeer intensief ( $\mathrm{met}$ wkk, belichting en een hoog netto-elektriciteitsverbruik).

In figuur 3.1 zijn alle bedrijven over de drie jaren weergegeven. Hierna worden de bedrijven uitgesplitst naar gewas. 


\subsubsection{Totale $\mathrm{CO}_{2}$-emissie per gewas}

In figuur 3.2 is de totale berekende $\mathrm{CO}_{2}$-emissie weergegeven per gewas.

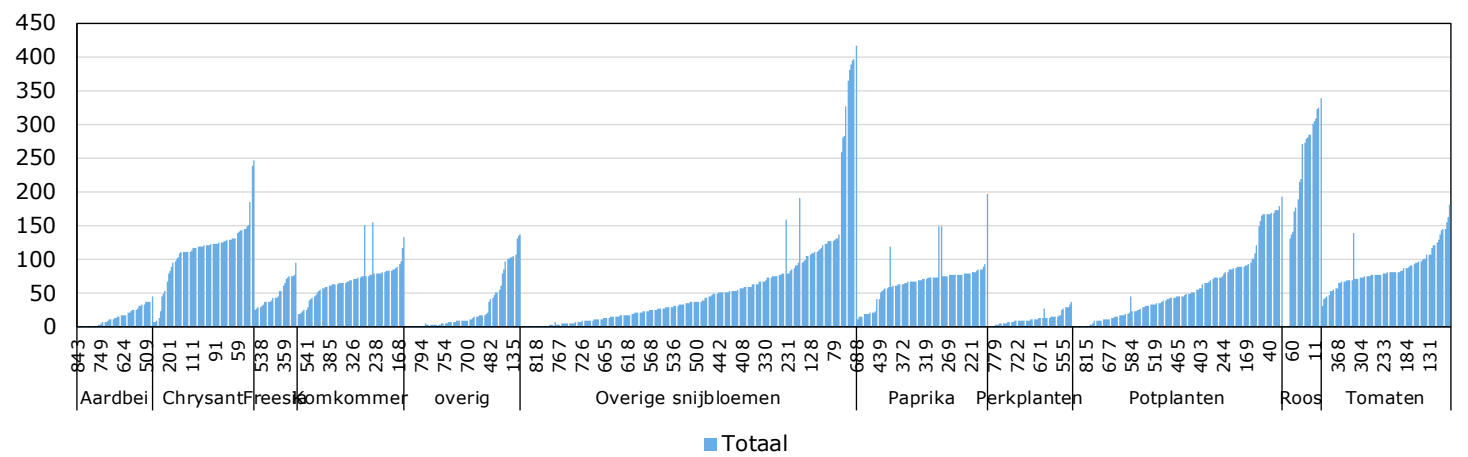

Figuur 3.2 $\mathrm{CO}_{2}$-emissie ( $\mathrm{kg} \mathrm{CO}_{2}$-eq. per $\mathrm{m}^{2}$ per jaar) ingedeeld naar gewas in de periode 20152017

Uit figuur 3.2 blijkt dat er grote verschillen zijn in $\mathrm{CO}_{2}$-emissie tussen de gewassen, maar ook binnen het gewas. Dit laatste is met name aan de orde bij de groepen overige snijbloemen, potplanten, roos, tomaat en overig. In de groep overige snijbloemen is de variatie zeer groot. Dit komt enerzijds door de verschillende gewassen en anderzijds door het al dan niet (intensief) belichten. Uit figuur 3.2 blijkt ook dat aardbeienbedrijven onder de $40 \mathrm{~kg} \mathrm{CO}_{2}$-equivalenten per $\mathrm{m}^{2}$ per jaar blijven, terwijl chrysantenbedrijven overwegend boven de $50 \mathrm{~kg} \mathrm{CO}_{2}$-equivalenten per $\mathrm{m}^{2}$ per jaar zitten. Op paprikabedrijven hebben de meeste bedrijven een $\mathrm{CO}_{2}$-emissie tussen de 40 en $90 \mathrm{~kg} \mathrm{CO}$ equivalenten per $\mathrm{m}^{2}$ per jaar. Op deze bedrijven wordt niet of nauwelijks belicht.

\subsubsection{Totale $\mathrm{CO}_{2}$-emissie en energieverbruik}

In deze paragraaf is de $\mathrm{CO}_{2}$-emissie gepresenteerd tezamen met het energieverbruik, waarbij onderscheid is gemaakt tussen het gasverbruik en het elektriciteitsverbruik. De bedrijven zijn ingedeeld naar berekende $\mathrm{CO}_{2}$-emissie.

\section{$\mathrm{CO}_{2}$-emissie en gasverbruik}

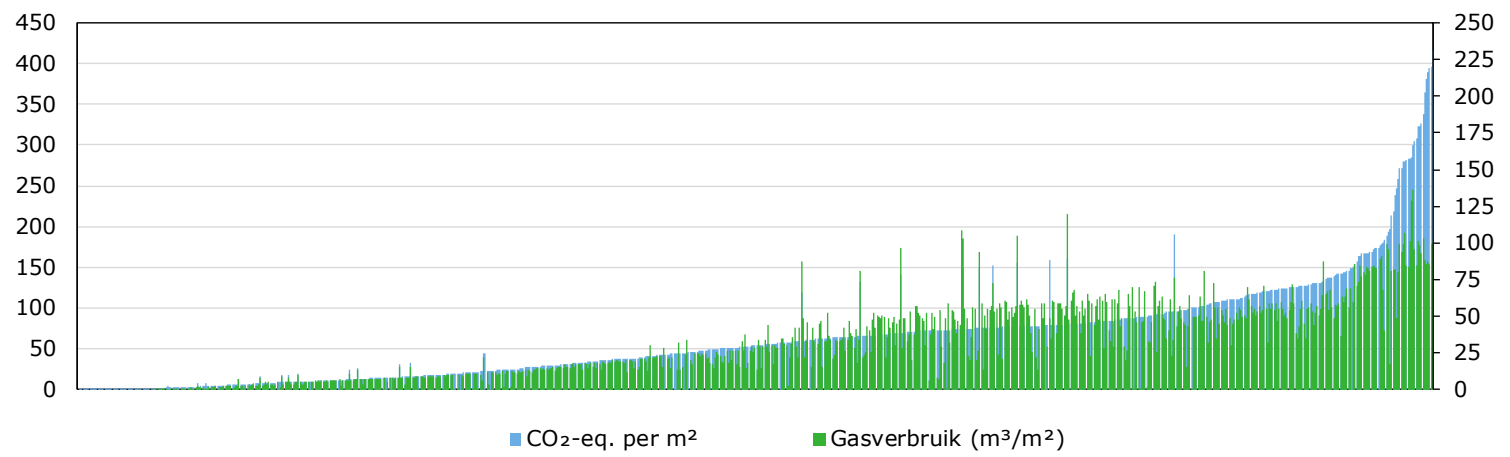

Figuur 3.3 $\mathrm{CO}_{2}$-emissie ( $\mathrm{kg} \mathrm{CO}$-eq. per $\mathrm{m}^{2}$ per jaar) en gasverbruik ( $\mathrm{m}^{3}$ per $\mathrm{m}^{2}$ per jaar), bedrijven gerangschikt naar de $\mathrm{CO}_{2}$-emissie in de periode 2015-2017

Uit figuur 3.3 blijkt dat de $\mathrm{CO}_{2}$-emissie samenhangt met het gasverbruik (van ketel en/of wkk). De $\mathrm{CO}_{2}$-emissie neemt toe bij een hoger gasverbruik. De $\mathrm{CO}_{2}$-emissie is echter ook afhankelijk van andere factoren. Dit is het duidelijkst zichtbaar in het meest rechter gedeelte op de $\mathrm{x}$-as. De $\mathrm{CO}_{2}$ emissie neemt op die bedrijven sterk toe door een hogere mate van belichting, met enerzijds inkoop 
van elektriciteit en anderzijds minder verkoop van zelfopgewekte elektriciteit, terwijl het gasverbruik minder toeneemt.

\section{$\mathrm{CO}_{2}$-emissie en elektriciteitsverbruik}

Figuur 3.4 laat zien dat de omvang van de $\mathrm{CO}_{2}$-emissie enigszins samenhangt met het elektriciteitsverbruik.

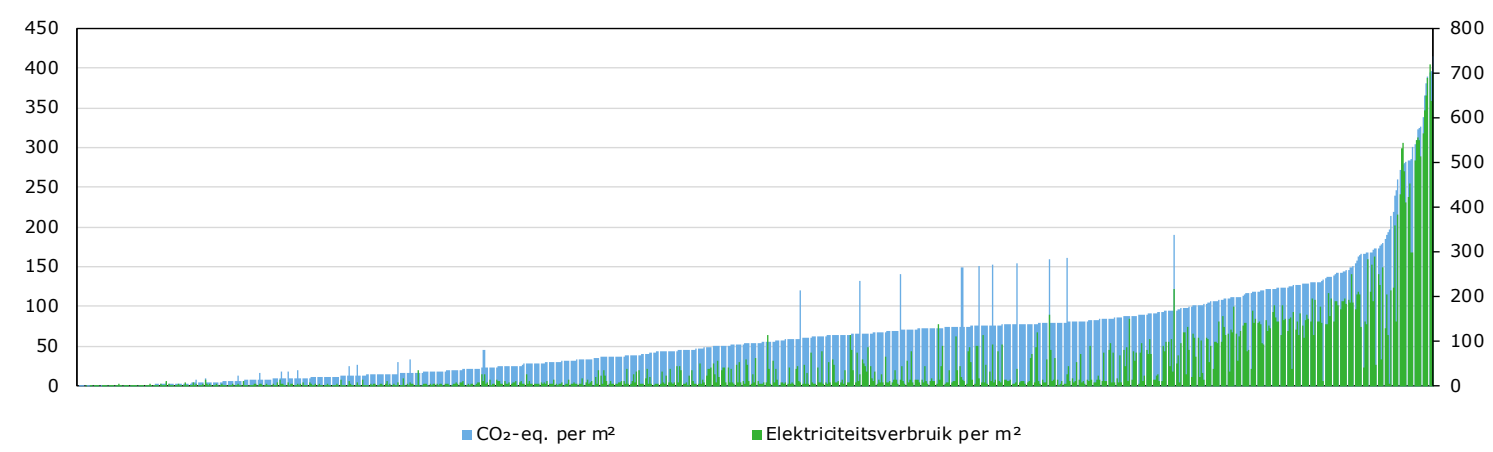

Figuur 3.4 $\mathrm{CO}_{2}$-emissie ( $\mathrm{kg} \mathrm{CO}_{2}$-eq. per $\mathrm{m}^{2}$ per jaar) en elektriciteitsverbruik ( $\mathrm{kWh}$ per $\mathrm{m}^{2}$ per jaar) per bedrijf in de periode 2015-2017

De bedrijven met de hoogste $\mathrm{CO}_{2}$-emissie hadden ook een hoog elektriciteitsverbruik. Dit houdt verband met het belichten van de gewassen. Dit type belichting (zogenaamd groeilicht) is energieintensief. Bedrijven met een lage $\mathrm{CO}_{2}$-emissie hebben ook een laag elektriciteitsverbruik. Deze bedrijven belichten soms wel, maar dan met fotoperiodisch licht om de daglengte te verlengen en daarmee de bloei te induceren bij zogenaamde kortedagplanten. Deze daglengteverlichting (vaak met gloeilampen) vraagt minder energie. In het middengedeelte van de $\mathrm{x}$-as in figuur 3.4 wordt de $\mathrm{CO}_{2}$ emissie meer bepaald door het terugleveren van met de wkk opgewekte elektriciteit aan het net en het energieverbruik voor verwarming.

Figuur 3.3 en 3.4 zijn ook gemaakt met een uitsplitsing per gewas. Het beeld dat figuur 3.3 en 3.4 geven, komt terug in figuur 3.5. De $\mathrm{CO}_{2}$-emissie hangt ook op gewasniveau meer samen met het elektriciteitsverbruik dan met het gasverbruik. 

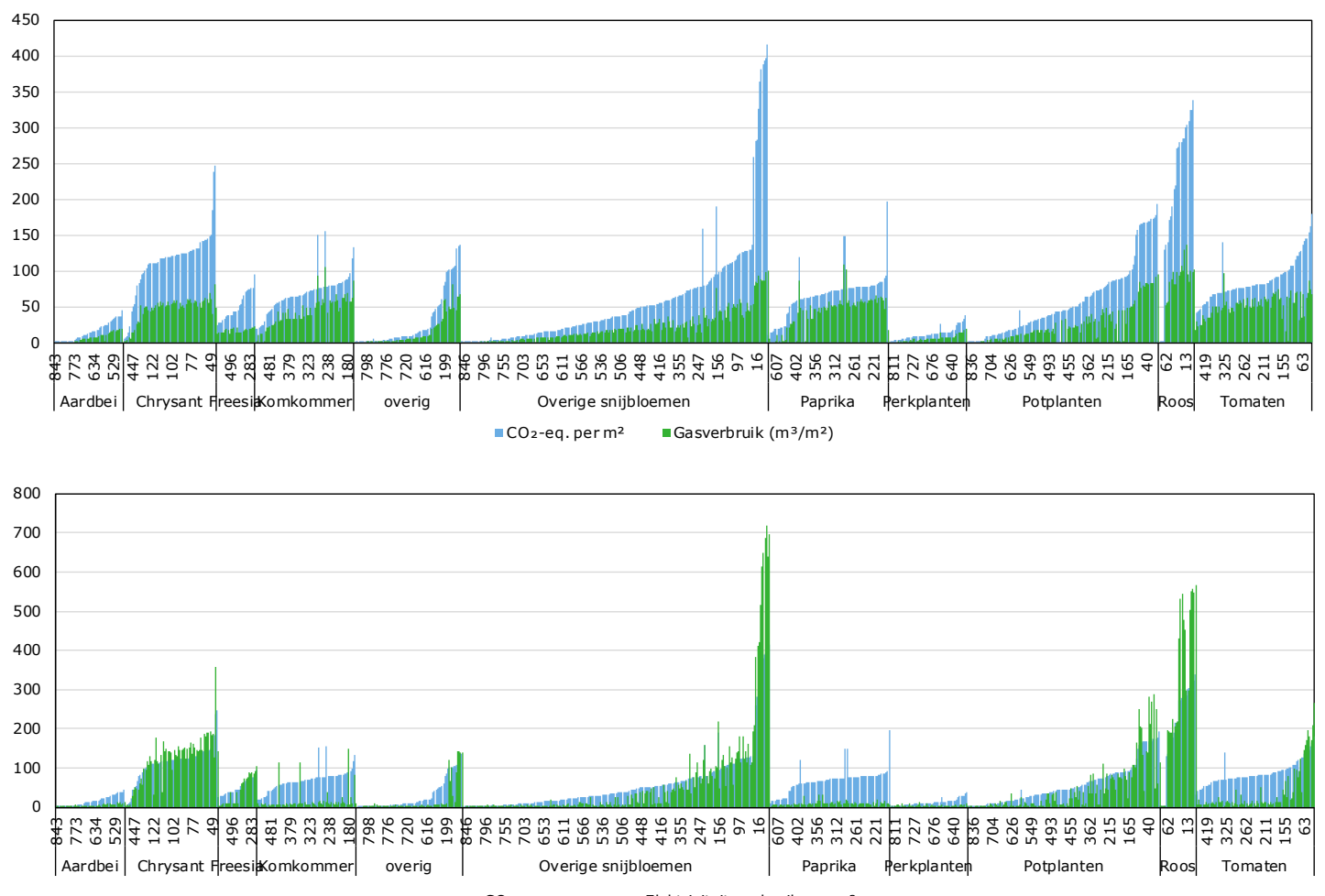

Figuur 3.5 $\mathrm{CO}_{2}$-emissie ( $\mathrm{kg} \mathrm{CO}$-eq. per $\mathrm{m}^{2}$ per jaar) in combinatie met gasverbruik $\left(\mathrm{m}^{3}\right.$ per $\mathrm{m}^{2}$ per jaar) (bovenste figuur) respectievelijk elektriciteitsverbruik ( $\mathrm{kWh} / \mathrm{m}^{2}$ per jaar) (onderste figuur) ingedeeld naar gewas in de periode 2015-2017

Naast het gas- en elektriciteitsverbruik zijn er ook andere factoren die de $\mathrm{CO}_{2}$-emissie bepalen. Zo kopen bedrijven warmte in (uit een centraal warmtesysteem) om de kas te verwarmen en verkopen bedrijven ook zelfgeproduceerde of uit de bodem onttrokken warmte aan onder andere collegatuinders. Bij elektriciteit is er het samenspel van inkoop, zelfopwekking (met wkk) en verkoop (aan tuinders of energieleverancier). Dit wordt geïllustreerd in de volgende paragraaf.

\subsubsection{Totale $\mathrm{CO}_{2}$-emissie en netto-energieverbruik}

In deze paragraaf is de $\mathrm{CO}_{2}$-emissie gerelateerd aan het netto-energieverbruik voor warmte enerzijds en elektriciteit anderzijds.

$\mathrm{CO}_{2}$-emissie en nettowarmteverbruik

In dit onderdeel is het energieverbruik voor verwarming uitgedrukt in kWh. Hierdoor is dit energieverbruik ook vergelijkbaar en sommeerbaar met het elektriciteitsverbruik.

Uit figuur 3.6 volgt dat de $\mathrm{CO}_{2}$-emissie op de bedrijven met bedekte teelt niet duidelijk samenhangt met het nettowarmteverbruik (het warmteverbruik voor de teelt en het bedrijf zelf, dus zonder levering van warmte aan derden). Dit geldt alleen voor de bedrijven met de hoogste $\mathrm{CO}_{2}$-emissie. De verklaring voor het laatste is dat deze bedrijven een relatief lage nettowarmtebehoefte hebben doordat de groeilampen al warmte afgeven, maar dat ze voor belichting grijze elektriciteit inkopen en daardoor een hoge $\mathrm{CO}_{2}$-emissie veroorzaken. 


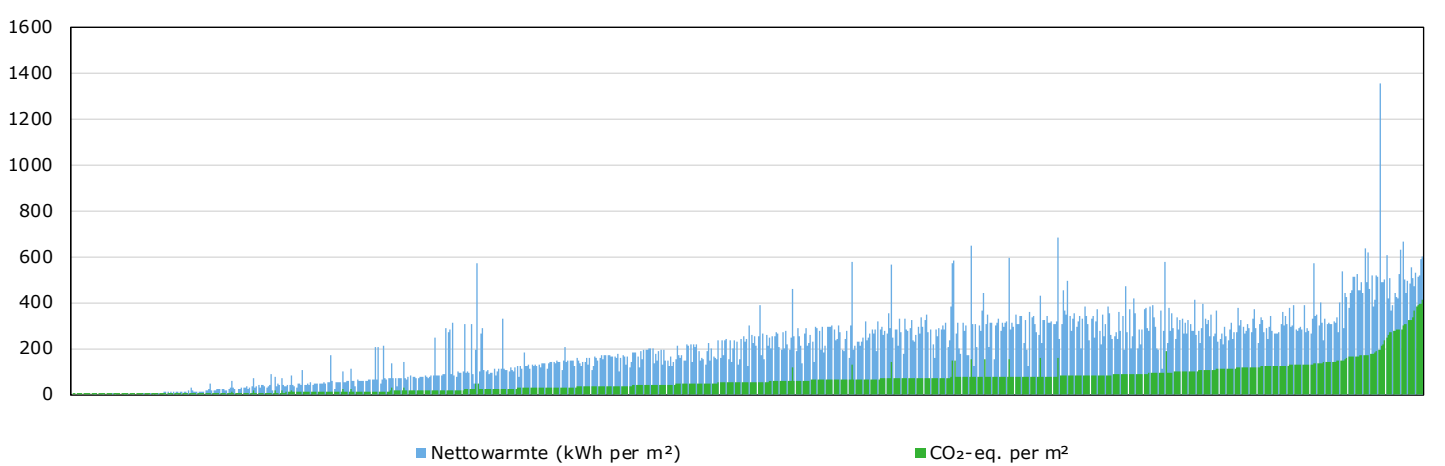

Figuur 3.6 $\mathrm{CO}_{2}$-emissie ( $\mathrm{kg} \mathrm{CO}_{2}$-eq. per $\mathrm{m}^{2}$ per jaar) en nettowarmteverbruik ( $\mathrm{kWh}$ per $\mathrm{m}^{2}$ per jaar) per bedrijf in de periode 2015-2017

\section{$\mathrm{CO}_{2}$-emissie en netto-elektriciteitsverbruik}

Figuur 3.7 laat zien dat de $\mathrm{CO}_{2}$-emissie alleen in het rechter deel van de grafiek duidelijk samenhangt met het netto-elektriciteitsverbruik op de bedrijven. Dit heeft deels te maken met het gegeven dat bedrijven die een wkk-installatie hebben de opgewekte elektriciteit deels of geheel terugleveren aan het net. De bedrijven die niet belichten hebben een laag elektriciteitsverbruik ten opzichte van belichters, gerelateerd aan de elektrische apparaten die het bedrijf gebruikt. De bedrijven met de hoogste $\mathrm{CO}_{2}$-emissie telen het meest intensief met belichting. De omvang van de $\mathrm{CO}_{2}$-emissie wordt bepaald door de belichtingsintensiteit en het aantal uur belichting.

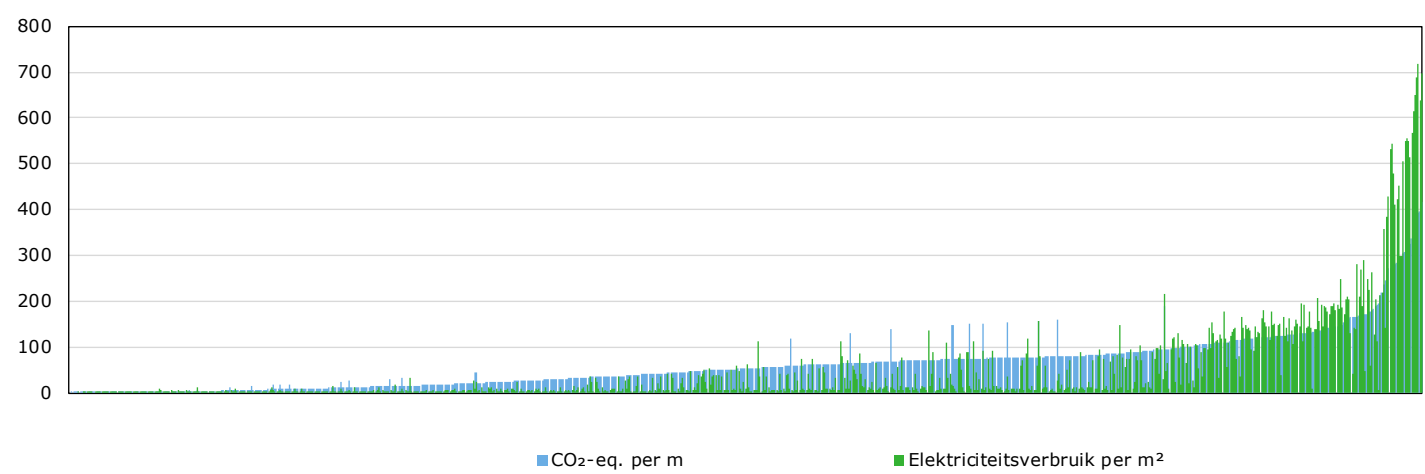

Figuur 3.7 $\mathrm{CO}_{2}$-emissie ( $\mathrm{kg} \mathrm{CO}$-eq. per $\mathrm{m}^{2}$ per jaar) en netto-elektriciteitsverbruik ( $\mathrm{kWh}$ per $\mathrm{m}^{2}$ per jaar) per bedrijf in de periode 2015-2017

Hierna is de $\mathrm{CO}_{2}$-emissie bekeken in relatie tot het netto-energieverbruik. Dit is het nettowarmteverbruik in combinatie met het netto-elektriciteitsverbruik (zie figuur 3.8).

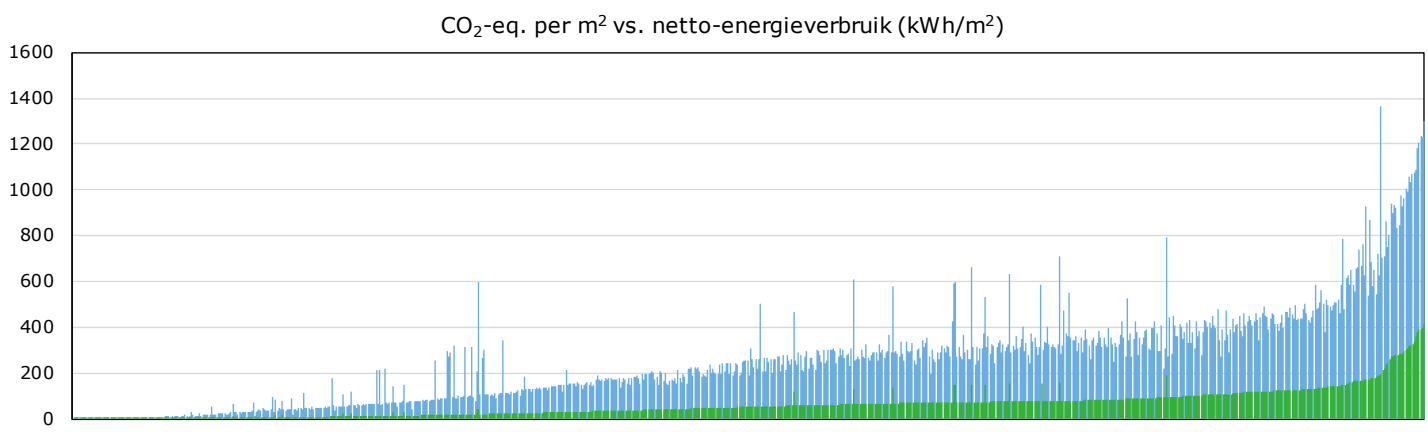

Figuur 3.8 $\mathrm{CO}_{2}$-emissie ( $\mathrm{kg} \mathrm{CO}_{2}$-eq. per $\mathrm{m}^{2}$ per jaar) en netto-energieverbruik ( $\mathrm{kWh}$ per $\mathrm{m}^{2}$ per jaar) per bedrijf in de periode 2015-2017 
Uit figuur 3.8 blijkt dat de $\mathrm{CO}_{2}$-emissie op de bedrijven met bedekte teelt de lijn volgt van het nettoenergieverbruik. Deze indicator (netto-energieverbruik) lijkt dus een geschikte maatstaf om bedrijven in categorieën in te delen. In de gebruikte data hebben alle bedrijven gas en elektriciteit als energiebron. Er zijn in de groep weinig bedrijven die energiebronnen gebruiken met een lage $\mathrm{CO}_{2}$ emissie, zoals aardwarmte of restwarmte. Overschakelen naar deze bronnen verkleint de relatie $\mathrm{CO}_{2}-$ emissie met het netto-energieverbruik. De relatie ligt er met het netto fossiele verbruik.

Ook volgt uit figuur 3.8 dat het gewas er blijkbaar minder toe doet (zie figuur 3.8a). Hierover meer in paragraaf 3.3 .

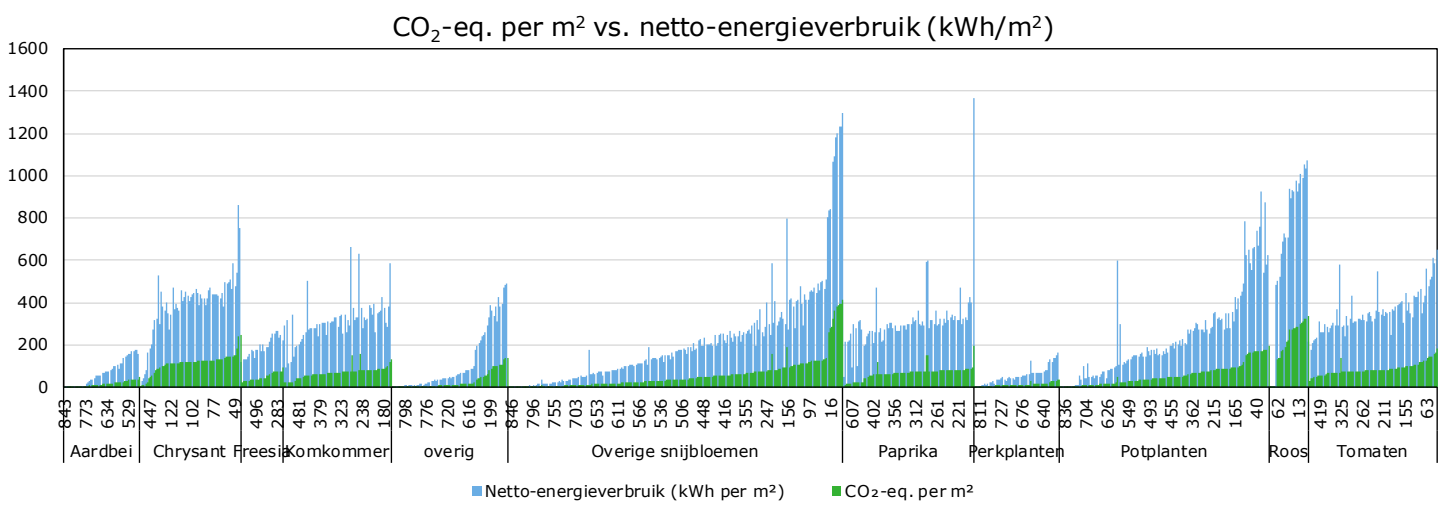

Figuur 3.8a $\mathrm{CO}_{2}$-emissie ( $\mathrm{kg} \mathrm{CO}$-eq. per $\mathrm{m}^{2}$ per jaar) en netto-energieverbruik ( $\mathrm{kWh}$ per $\mathrm{m}^{2}$ per jaar) ingedeeld naar gewas in de periode 2015-2017

\subsubsection{Totale $\mathrm{CO}_{2}$-emissie en belichting}

Het is bekend dat belichting en met name het gebruik van groeilicht de teelt qua energieverbruik intensiveert. Belichten kan de productie - en bij bepaalde gewassen ook de productkwaliteit - positief beïnvloeden.

In figuur 3.9 is de $\mathrm{CO}_{2}$-emissie bekeken in relatie tot het gebruik van belichting.

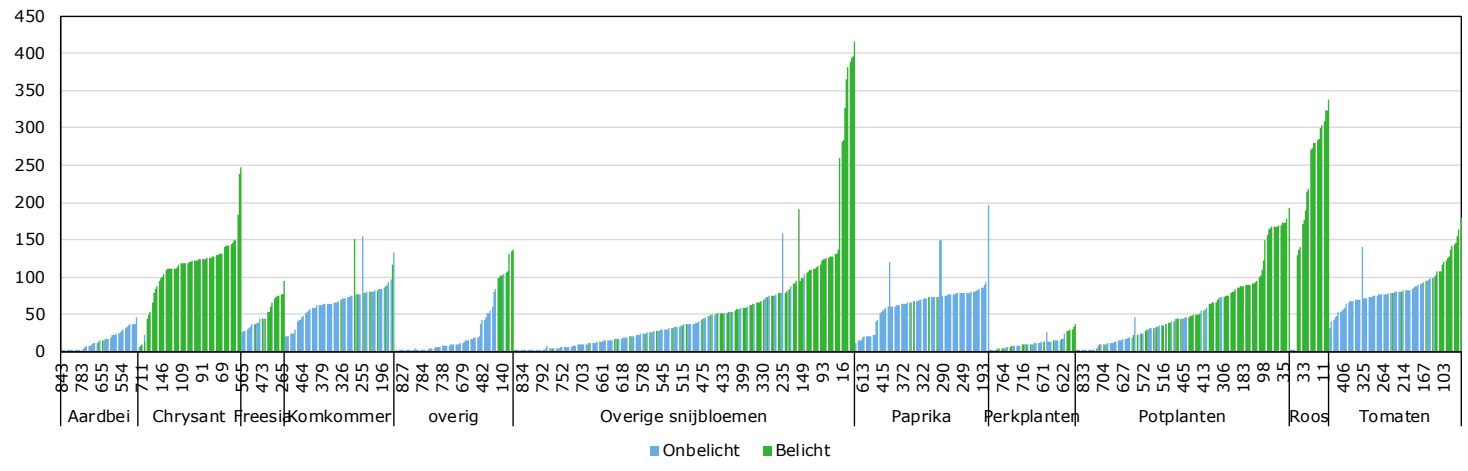

Figuur $3.9 \mathrm{CO}_{2}$-emissie ( $\mathrm{kg} \mathrm{CO}$-eq. per $\mathrm{m}^{2}$ per jaar) en belichting (wel/niet) ingedeeld naar gewas in de periode 2015-2017

Figuur 3.9 laat zien dat belichting duidelijk van invloed is op de $\mathrm{CO}_{2}$-emissie, omdat de bedrijven die belichten (de rode staven) de hoogste $\mathrm{CO}_{2}$-emissie hebben. Ook wordt uit figuur 3.9 duidelijk dat in deze groep bij bepaalde gewassen niet of nauwelijks wordt belicht (vrijwel alle lijnen zijn blauw). Dit betreft onder andere aardbei, paprika en komkommer. Bij de andere gewassen komt belichting meer voor. Van roos en chrysant is bekend dat overwegend wordt belicht. In enkele gewassen, zoals tomaat, is belichting in opkomst. 
Een andere en duidelijkere presentatiewijze over het effect van belichting op de $\mathrm{CO}_{2}$-emissie is hieronder weergegeven (zie figuur 3.9a).
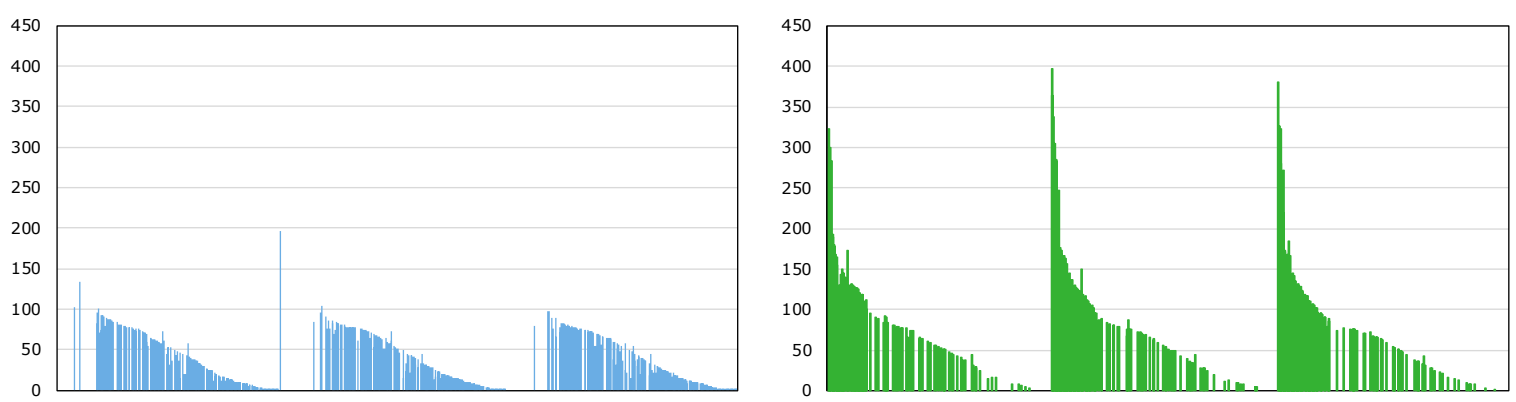

Figuur 3.9a $\mathrm{CO}_{2}$-emissie ( $\mathrm{kg} \mathrm{CO}$-eq. per $\mathrm{m}^{2}$ per jaar) van niet-belichtende bedrijven (links) en belichtende bedrijven (rechts) per bedrijf in de periode 2015-2017

De groep belichtende bedrijven kent een groter aantal bedrijven met een emissie tot boven 50 en $100 \mathrm{~kg} \mathrm{CO}$-equivalenten per $\mathrm{m}^{2}$ en piek boven de $300 \mathrm{~kg} \mathrm{CO}$-equivalenten per $\mathrm{m}^{2}$.

\subsubsection{Totale $\mathrm{CO}_{2}$-emissie en zelf opwekken van elektriciteit met een wkk}

Voor bedrijven die (intensief) belichten, was in het verleden de aanschaf van een wkk-installatie interessant uit energietechnisch en economisch oogpunt. Figuur 3.10 toont de $\mathrm{CO}_{2}$-emissie in relatie tot de aanwezigheid van een wkk-installatie op het bedrijf.

In figuur 3.10 is in grote lijnen hetzelfde beeld te zien als in figuur 3.9, met als verschil dat bepaalde bedrijven (met onder andere komkommer en paprika) een wkk-installatie hebben en de geproduceerde elektriciteit terugleveren aan het net omdat ze niet belichten. In de tijd van de aanschaf van de wkk-installaties (rond het jaar 2000) was het economisch interessant om een wkk te hebben zonder te belichten door de gunstige verhouding tussen de gasprijs en de elektriciteitsprijs (de zogenaamde 'sparkspread').

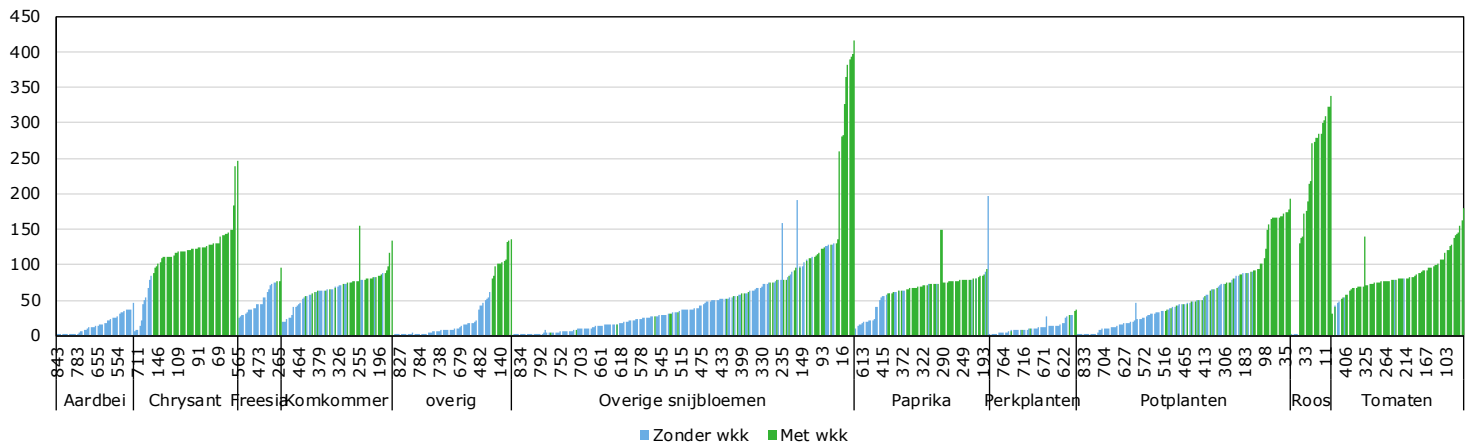

Figuur $3.10 \mathrm{CO}_{2}$-emissie ( $\mathrm{kg} \mathrm{CO}$-eq. per $\mathrm{m}^{2}$ per jaar) en aanwezigheid van een wkk (wel/niet) ingedeeld naar gewas in de periode 2015-2017

Daarnaast was ook de $\mathrm{CO}_{2}$ die na reiniging van het rookgas beschikbaar komt gunstig. Door de opwekking van elektriciteit (circa 40\% van de energie-inhoud) komt er per hoeveelheid warmte (circa $55 \%$ ) 95/55 keer zoveel $\mathrm{CO}_{2}$ beschikbaar in vergelijking met alleen verwarmen met een gasketel.

Een andere en duidelijkere presentatiewijze is hieronder weergegeven (figuur 3.10a). 

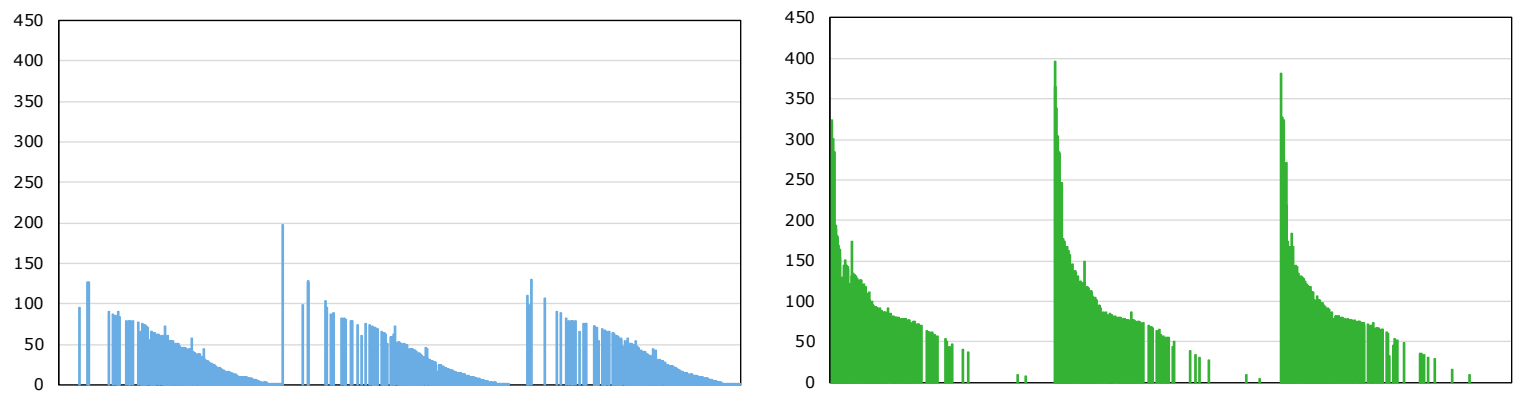

Figuur 3.10a $\mathrm{CO}_{2}$-emissie ( $\mathrm{kg} \mathrm{CO}$-eq. per $\mathrm{m}^{2}$ per jaar) op bedrijven zonder (links) en bedrijven met wkk (rechts) per bedrijf in de periode 2015-2017

De groep bedrijven met een wkk kent een groter aantal bedrijven met een emissie boven 50 en $100 \mathrm{~kg} \mathrm{CO}_{2}$-equivalenten per $\mathrm{m}^{2}$ en een piek tot boven de $300 \mathrm{~kg} \mathrm{CO}_{2}$-equivalenten per $\mathrm{m}^{2}$. De verschillen lopen parallel aan wat we zagen bij de vergelijking belicht-onbelicht.

\subsubsection{Totale $\mathrm{CO}_{2}$-emissie en aantal schermen}

In figuur 3.11 is de $\mathrm{CO}_{2}$-emissie weergegeven in relatie tot het aantal schermen op de bedrijven met bedekte teelt.

Sinds de introductie van energiebesparende schermen in de jaren tachtig van de twintigste eeuw is het gebruik van schermen nu gemeengoed bij gestookte teelten en is er weinig variatie in gebruik. Er zijn grote energiebesparingen gerealiseerd, met name in het aardgasverbruik. Uit figuur 3.11 blijkt dat het aantal schermen geen belangrijke factor is om de variatie in $\mathrm{CO}_{2}$-emissie te verklaren. Schermen leveren weliswaar een energiebesparing op, maar zijn nauwelijks van invloed op de variatie in $\mathrm{CO}_{2}-$ emissie. Kortom, het aantal schermen is geen maatstaf om bedrijven in te delen. Mogelijk is er wel een relatie als er gekeken wordt naar het besparingspercentage en het aantal uur dat het scherm gebruikt wordt.
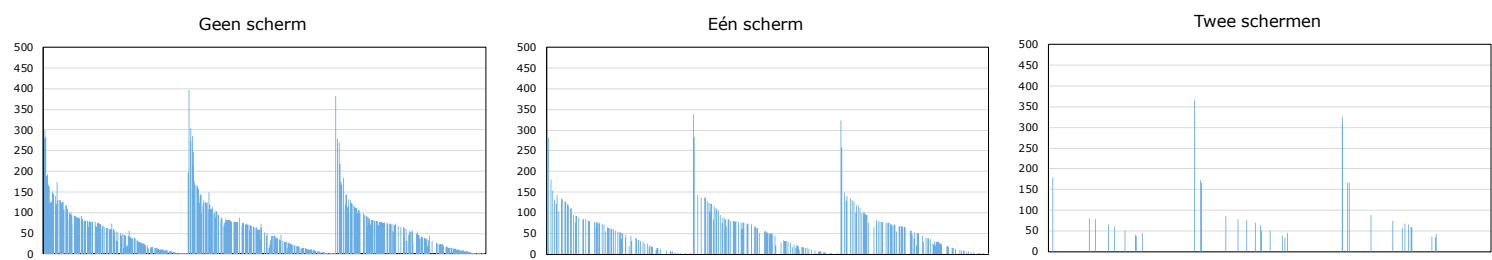

Figuur 3.11 $\mathrm{CO}_{2}$-emissie ( $\mathrm{kg} \mathrm{CO}$-eq. per $\mathrm{m}^{2}$ per jaar) en aantal (energie)schermen per bedrijf (geen tot twee) in de periode 2015-2017

\subsubsection{Totale $\mathrm{CO}_{2}$-emissie en leeftijd kassen}

Ook is nagegaan of de $\mathrm{CO}_{2}$-emissie samenhangt met de leeftijd of ouderdom van de kasopstanden (zie figuur 3.12). Oude kasopstanden zijn vaak meer 'lek' dan nieuwe of moderne kassen. 


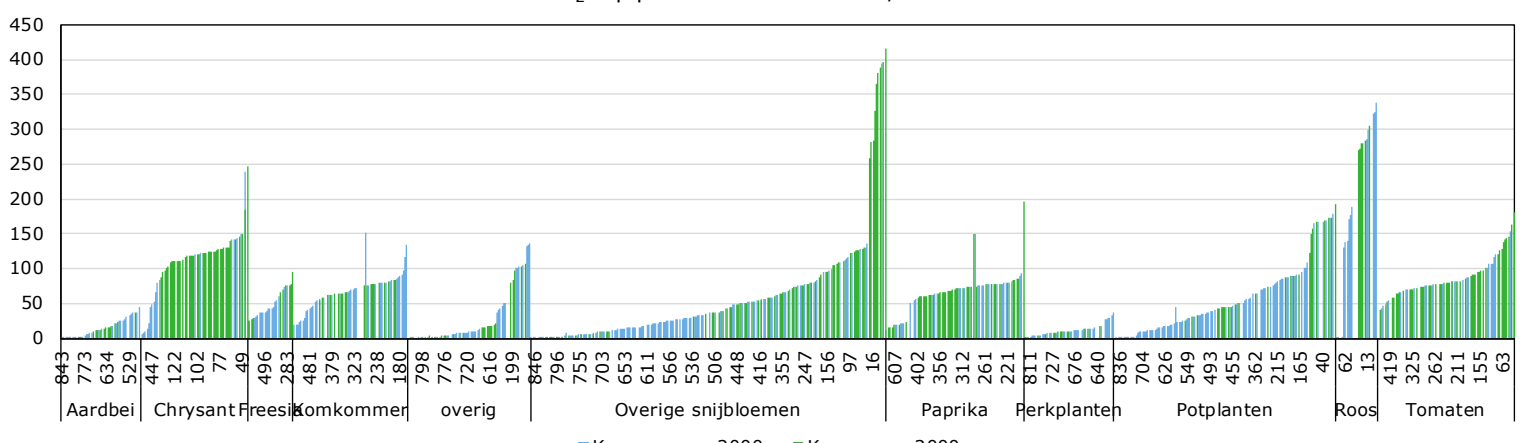

Kas van voor 2000 Kas van na 2000

Figuur $3.12 \mathrm{CO}_{2}$-emissie ( $\mathrm{kg} \mathrm{CO}_{2}$-eq. per $\mathrm{m}^{2}$ per jaar) en leeftijd kassen (ouder of jonger dan 2000) ingedeeld naar gewas in de periode 2015-2017

Figuur 3.12 laat zien dat nieuwe en hogere kassen eerder een hogere $\mathrm{CO}_{2}$-emissie hebben dan bedrijven met oudere kassen. De verklaring hiervoor ligt in het gegeven dat in nieuwe of moderne kassen meer of intensiever wordt belicht en op bedrijven met oudere kassen veelal gewassen worden geteeld met een lagere warmtebehoefte en/of niet of nauwelijks wordt belicht.

Dit betekent dat de leeftijd van de kassen geen geschikt indelingscriterium lijkt voor de variatie in en omvang van de $\mathrm{CO}_{2}$-emissie.

Een andere en duidelijkere presentatiewijze is hieronder weergegeven (figuur 3.12a).

$\mathrm{CO}_{2}$-eq. per $\mathrm{m}^{2}$ en kassen van voor 2000

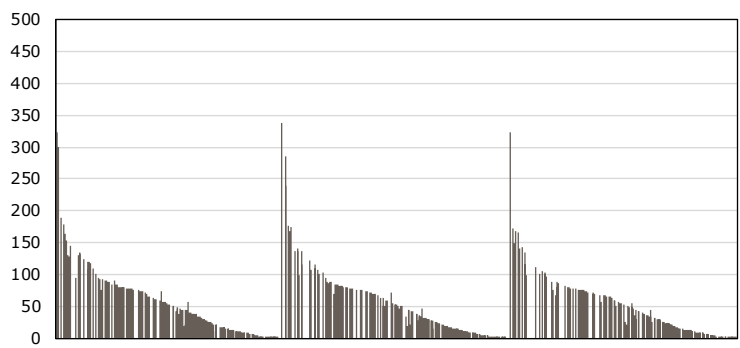

$\mathrm{CO}_{2}$-eq. per $\mathrm{m}^{2}$ en kassen van na 2000

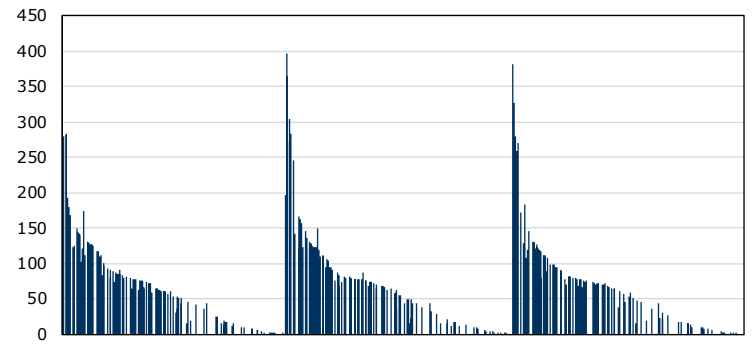

Figuur 3.12a $\mathrm{CO}_{2}$-emissie ( $\mathrm{kg} \mathrm{CO}$-eq. per $\mathrm{m}^{2}$ per jaar) op bedrijven met kassen van voor 2000 (links) en bedrijven met kassen van na 2000 (rechts) per bedrijf in de periode 2015-2017

\subsubsection{Totale $\mathrm{CO}_{2}$-emissie en haar bestanddelen}

In de vorige paragrafen is de relatie tussen de totale $\mathrm{CO}_{2}$-emissie en verschillende invloedfactoren besproken. In onderstaande figuur 3.13 is een overzicht opgenomen waarin de samenstelling van de totale $\mathrm{CO}_{2}$-emissie is weergegeven. Dit betreft de $\mathrm{CO}_{2}$-emissie gerelateerd aan de inkoop van energie (gas, elektriciteit, warmte en koude), de inkoop van $\mathrm{CO}_{2}$ (via de weg of buis) en de verkoop van elektriciteit en warmte aan derden. De laatste categorie houdt een negatieve $\mathrm{CO}_{2}$-emissie in die wordt afgetrokken van de bruto- $\mathrm{CO}_{2}$-emissie (van gas, elektra, warmte en ingekocht $\mathrm{CO}_{2}$ ), omdat deze buiten de systeemgrens van de kas ligt.

In figuur 3.13 is dit alleen voor het jaar 2017 weergegeven, omdat de figuur anders moeilijk leesbaar is. De andere jaren laten een vergelijkbaar beeld zien (zie bijlage 2). Uit figuur 3.13 is op te maken dat in de linkerhelft van de $x$-as tot een niveau van circa $75 \mathrm{~kg} \mathrm{CO}_{2}$-equivalenten per $\mathrm{m}^{2}$ de $\mathrm{CO}_{2}-$ emissie hoofdzakelijk wordt bepaald door het verbruik van gas voor de ketel en elektriciteit. Bij enkele bedrijven (blauw/groene staven) is de $\mathrm{CO}_{2}$-emissie te wijten aan de aankoop van (fossiel geproduceerde) restwarmte. In de rechterhelft van de $x$-as met meer dan circa $75 \mathrm{~kg} \mathrm{CO}_{2}-$ equivalenten per $\mathrm{m}^{2}$ is de $\mathrm{CO}_{2}$-emissie in grote mate bepaald door het gasverbruik voor de wkk en de 
inkoop van grijze stroom voor intensieve belichting. Ook is in de rechterhelft van de $x$-as te zien dat bedrijven tevens een 'negatieve' $\mathrm{CO}_{2}$-emissie hebben, hoofdzakelijk veroorzaakt door de verkoop van elektriciteit aan derden. Deze $\mathrm{CO}_{2}$-emissie wordt in mindering gebracht op de bruto- $\mathrm{CO}_{2}$-emissie, die is berekend op basis van het verbruik van energiedragers.

$\mathrm{CO}_{2}$-eq. per $\mathrm{m}^{2}$ en bestanddelen in 2017

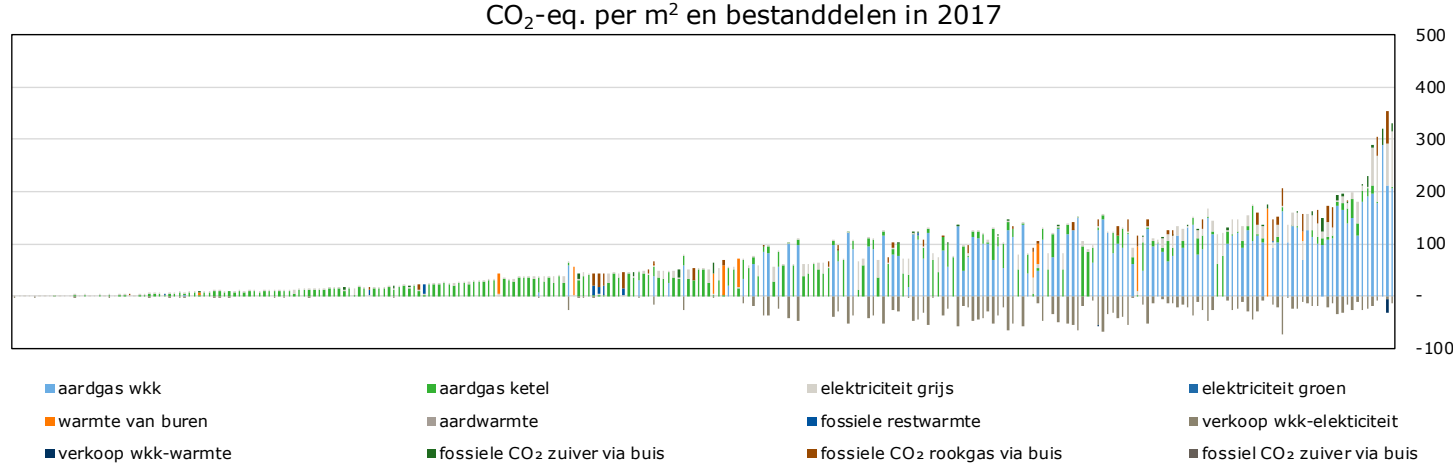

Figuur 3.13 $\mathrm{CO}_{2}$-emissie ( $\mathrm{kg} \mathrm{CO}$-eq. per $\mathrm{m}^{2}$ per jaar) en haar bestanddelen per bedrijf in 2017

De uitkomsten in figuur 3.13 werpen een gevarieerd beeld op de $\mathrm{CO}_{2}$-emissie op de Informatienetbedrijven met bedekte teelt. Wat betekent dit voor het ontwerpen van indelingscategorieën voor On the Way to PlanetProof-bedrijven in het kader van het streven van SMK om gecertificeerde bedrijven te stimuleren de broeikasgasemissies verder te verminderen? In paragraaf 3.3 wordt hierop verder ingegaan.

Hierna worden de relaties tussen de $\mathrm{CO}_{2}$-emissie en de invloedfactoren statistisch getoetst.

\subsubsection{Regressieanalyse totale $\mathrm{CO}_{2}$-emissie en invloedfactoren}

Met de statistieksoftware SPSS is een regressieanalyse uitgevoerd van $\mathrm{CO}_{2}$-emissie in relatie tot gasverbruik, elektriciteitsverbruik, nettowarmteverbruik, netto-elektriciteitsverbruik, wel/geen belichting, wel/geen wkk, aantal (energie)schermen en leeftijd kassen (van voor/na 2000). In tabel 3.1 zijn de resultaten vermeld.

Uit tabel 3.1 blijkt dat het netto-elektriciteitsverbruik de meest verklarende factor is voor de variatie in $\mathrm{CO}_{2}$-emissie met een $\mathrm{R}$-waarde van 0,895. Op de tweede en derde plaats volgen het gasverbruik en het nettowarmteverbruik met een toename van de R-waarde tot 0,978 respectievelijk 0,988. Het aantal schermen, de aanwezigheid van belichting en enkele gewassen zijn weliswaar significant qua invloed, maar voegen weinig meer aan toe aan de verklaring van de variatie in $\mathrm{CO}_{2}$-emissie (zie $\mathrm{R}$-square in de tabel). Het effect van het gasverbruik is onderdeel van de effecten van het nettoelektriciteitsverbruik en het nettowarmteverbruik. Er is hierbij sprake van een zogenaamd getrapt model. 
Tabel 3.1 Meest verklarende factoren uit de regressieanalyse van de $\mathrm{CO}_{2}$-emissie en invloedfactoren

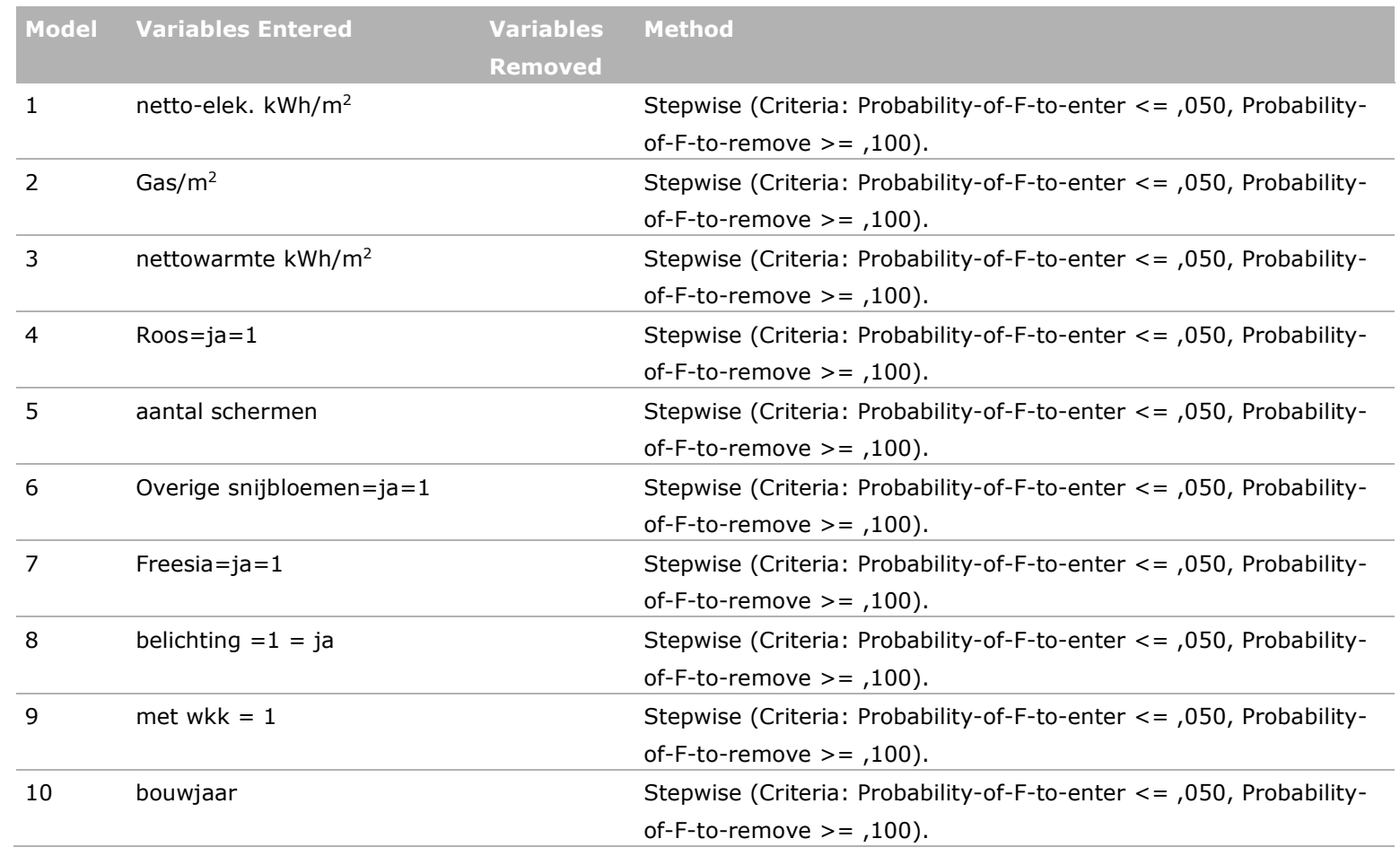

a. Dependent Variable: attributie emissie zonder $\mathrm{CO}_{2}$-aankoop

\begin{tabular}{llllrr} 
Model Summary & \multicolumn{1}{l}{$\mathbf{R}$} & R Square & Adjusted R Square Std. Error of the Estimate \\
1 &, $895^{\mathrm{a}}$ & 0,801 & 0,801 & 27,364810953472000 \\
\hline 2 &, $978^{\mathrm{b}}$ & 0,957 & 0,956 & 12,802522407471100 \\
\hline 3 &, $988^{\mathrm{c}}$ & 0,976 & 0,976 & 9,580054611651410 \\
\hline 4 &, $988^{\mathrm{d}}$ & 0,976 & 0,976 & 9,498535668754920 \\
\hline 5 &, $988^{\mathrm{e}}$ & 0,977 & 0,976 & 9,423374651012350 \\
\hline 6 &, $988^{\mathrm{f}}$ & 0,977 & 0,977 & 9,377939590839210 \\
\hline 7 &, $988^{\mathrm{g}}$ & 0,977 & 0,977 & 9,341539966389400 \\
\hline 8 &, $989^{\mathrm{h}}$ & 0,977 & 0,977 & 9,315855652259740 \\
\hline 9 &, $989^{\mathrm{i}}$ & 0,977 & 0,977 & 9,284318520512190 \\
\hline 10 &, $989^{\mathrm{j}}$ & 0,978 & 0,977 & 9,262841875817510
\end{tabular}

a. Predictors: (Constant), netto-elek. $\mathrm{kWh} / \mathrm{m}^{2}$

b. Predictors: (Constant), netto-elek. kWh $/ \mathrm{m}^{2}$, Gas $/ \mathrm{m}^{2}$

c. Predictors: (Constant), netto-elek. $\mathrm{kWh} / \mathrm{m}^{2}$, Gas $/ \mathrm{m}^{2}$, nettowarmte $\mathrm{kWh} / \mathrm{m}^{2}$

d. Predictors: (Constant), netto-elek. $\mathrm{kWh} / \mathrm{m}^{2}, \mathrm{Gas} / \mathrm{m}^{2}$, nettowarmte $\mathrm{kWh} / \mathrm{m}^{2}$, Roos $=\mathrm{ja}=1$

e. Predictors: (Constant), netto-elek. $\mathrm{kWh} / \mathrm{m}^{2}, \mathrm{Gas} / \mathrm{m}^{2}$, nettowarmte $\mathrm{kWh} / \mathrm{m}^{2}, \mathrm{Roos}=\mathrm{ja}=1$, aantal schermen

f. Predictors: (Constant), netto-elek. $\mathrm{kWh} / \mathrm{m}^{2}, \mathrm{Gas} / \mathrm{m}^{2}$, nettowarmte $\mathrm{kWh} / \mathrm{m}^{2}$, Roos $=\mathrm{ja}=1$, aantal schermen, Overige snijbloemen $=j a=1$

g. Predictors: (Constant), netto-elek. $\mathrm{kWh} / \mathrm{m}^{2}, \mathrm{Gas} / \mathrm{m}^{2}$, nettowarmte $\mathrm{kWh} / \mathrm{m}^{2}, \mathrm{Roos}=\mathrm{ja}=1$, aantal schermen, Overige snijbloemen $=\mathrm{ja}=1$, Freesia $=j a=1$

h. Predictors: (Constant), netto-elek. $\mathrm{kWh} / \mathrm{m}^{2}, \mathrm{Gas} / \mathrm{m}^{2}$, nettowarmte $\mathrm{kWh} / \mathrm{m}^{2}, \mathrm{Roos}=\mathrm{ja}=1$, aantal schermen, Overige snijbloemen $=\mathrm{ja}=1$, Freesia $=j a=1$, belichting $=1=j a$

i. Predictors: (Constant), netto-elek. $\mathrm{kWh} / \mathrm{m}^{2}, \mathrm{Gas} / \mathrm{m}^{2}$, nettowarmte $\mathrm{kWh} / \mathrm{m}^{2}, \mathrm{Roos}=\mathrm{ja}=1$, aantal schermen, Overige snijbloemen $=\mathrm{ja}=1$, Freesia $=j a=1$, belichting $=1=j a$, met $w k k=1$

j. Predictors: (Constant), netto-elek. $\mathrm{kWh} / \mathrm{m}^{2}, \mathrm{Gas} / \mathrm{m}^{2}$, nettowarmte $\mathrm{kWh} / \mathrm{m}^{2}, \mathrm{Roos}=\mathrm{ja}=1$, aantal schermen, Overige snijbloemen $=\mathrm{ja}=1$, Freesia $=j a=1$, belichting $=1=j a$, met $w k k=1$, bouwjaar

Uit tabel 3.2 is af te leiden dat het totale netto-energieverbruik (in $\mathrm{kWh} / \mathrm{m}^{2}$ ) - in deze dataset geheel fossiel - de grootste significante of verklarende factor is met een $R^{2}$ van 0,961 (zie de regel nettoenergie $\mathrm{kWh} / \mathrm{m}^{2}$ ). Feitelijk is dit de invloed van de omvang van het energieverbruik voor verwarming en belichting samen. Het verkopen van elektriciteit en warmte aan derden is hierbij, zoals eerder 
aangegeven, buiten de totale omvang van de $\mathrm{CO}_{2}$-emissie gelaten door de daaraan gerelateerde $\mathrm{CO}_{2}-$ emissie in mindering te brengen op de bruto- $\mathrm{CO}_{2}$-emissie. Deze $\mathrm{CO}_{2}$-emissie is bepaald op basis van het energetische rendement van de wkk. Dezelfde exercitie is uitgevoerd, waarbij het gewas ook als verklarende variabele is meegenomen. Uit de regressieanalyse blijkt dat het gewas er minder toe doet (zie tabel 3.2). Alleen bij de gewassen roos, chrysant en perkplanten (zie gele velden in tabel 3.2) is er enige verklaring voor de verschillen in $\mathrm{CO}_{2}$-emissie.

In paragraaf 3.3 wordt hier verder op ingegaan aan de hand van de regressievergelijking op basis van de twee belangrijkste en meest significante variabelen (netto-elektriciteitsverbruik en nettowarmteverbruik). 
Tabel 3.2 Correlaties uit de regressieanalyse van de $\mathrm{CO}_{2}$-emissie en invloedfactoren

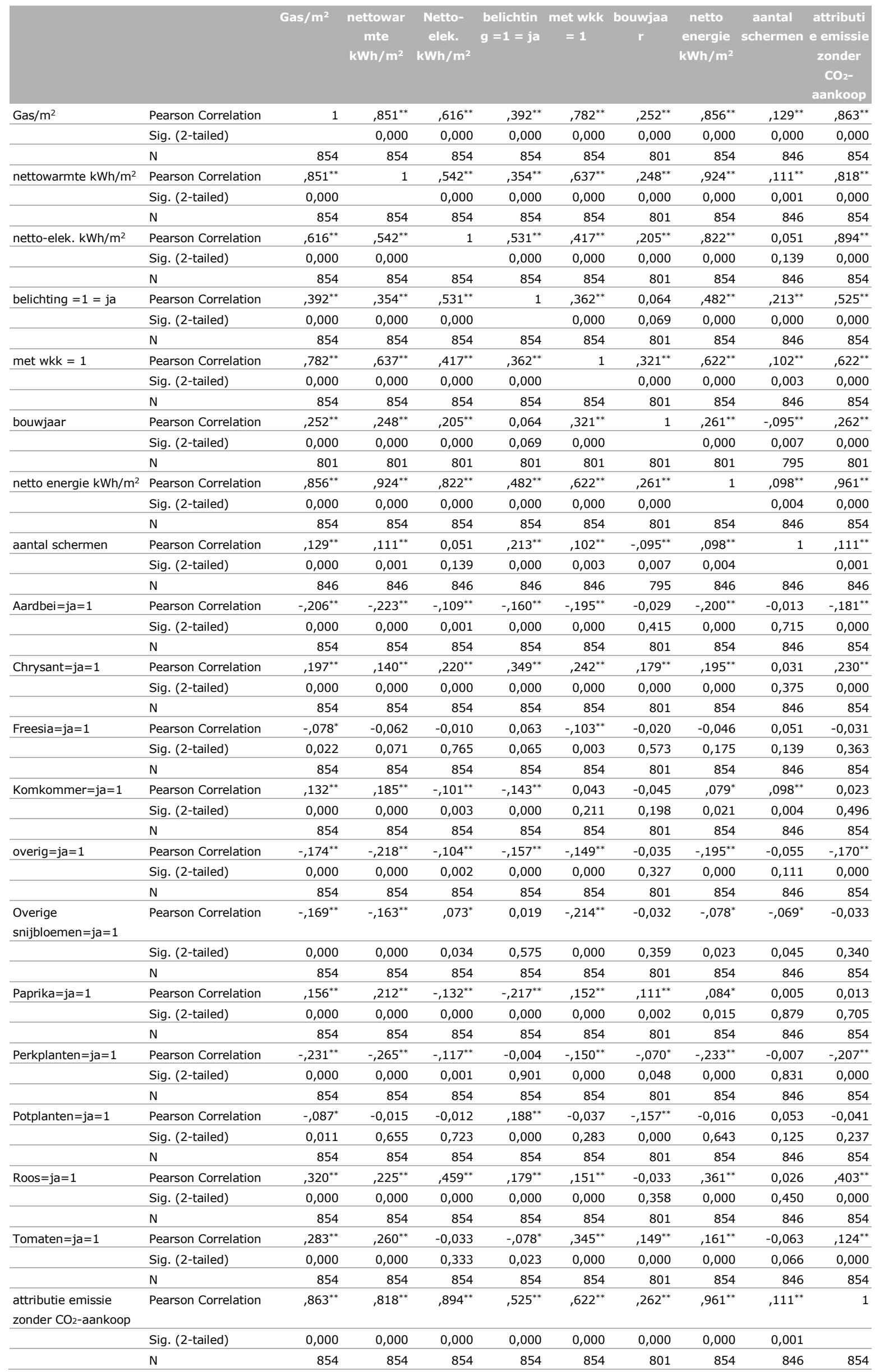

* Correlation is significant at the 0.01 level (2-tailed)

** Correlation is significant at the 0.05 level (2-tailed) 
Uit tabel 3.2 blijkt ook dat het gasverbruik na het netto-elektriciteitsverbruik de tweede significante factor is voor de $\mathrm{CO}_{2}$-emissie (zie geel gemarkeerde velden in de kolom 'attributie $\mathrm{CO}_{2}$-emissie zonder $\mathrm{CO}_{2}$-aankoop'). Het gasverbruik bepaalt mede de impact van het netto-elektriciteitsverbruik en het nettowarmteverbruik op de $\mathrm{CO}_{2}$-emissie. Gas dat wordt verstookt in de wkk-installatie met als doel om elektriciteit en warmte te produceren leidt immers tot $\mathrm{CO}_{2}$-emissie.

\subsubsection{Vergelijking bepalingsmethoden broeikasgasemissies}

In dit onderzoek is gekozen voor de attributiemethode ter bepaling van de broeikasgasemissies. Er zijn nog twee andere bepalingsmethoden: de substitutiemethode en de IPCC-methode. De IPCCmethode is de bepalingsmethode die het IPCC (Intergovernmental Panel on Climate Change) hanteert voor de $\mathrm{CO}_{2}$-emissie. Hieronder is ter illustratie in figuur 3.14 de verschillen in $\mathrm{CO}_{2}$-emissie grafisch weergegeven.

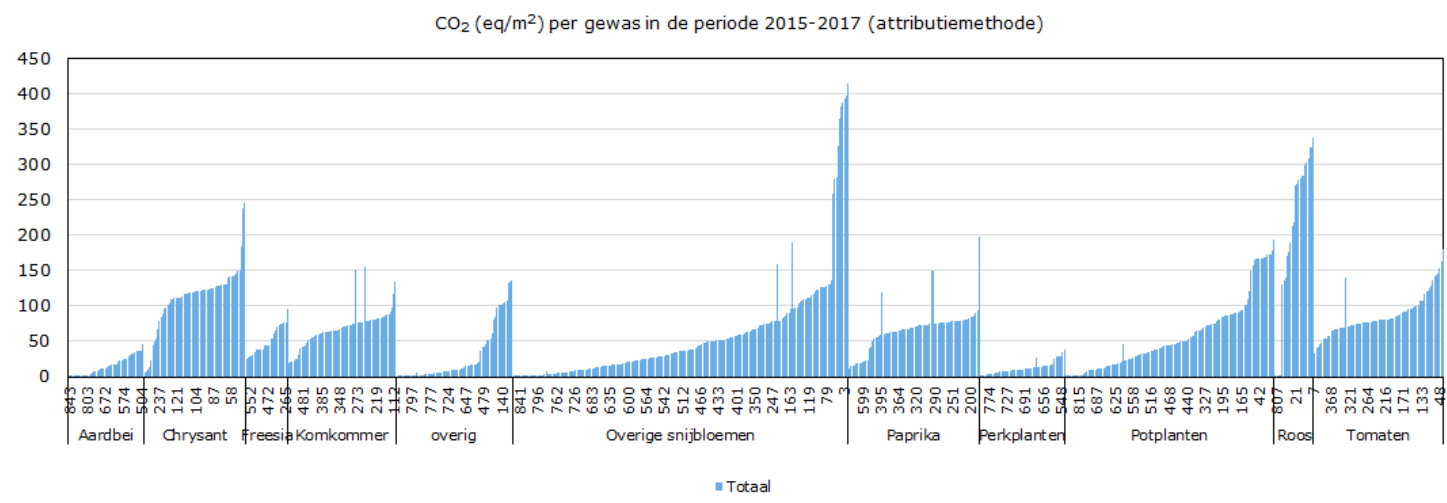

$\mathrm{CO}_{2}\left(\mathrm{eq} / \mathrm{m}^{2}\right)$ per gewas in de periode 2015-2017 (substitutiemethode)

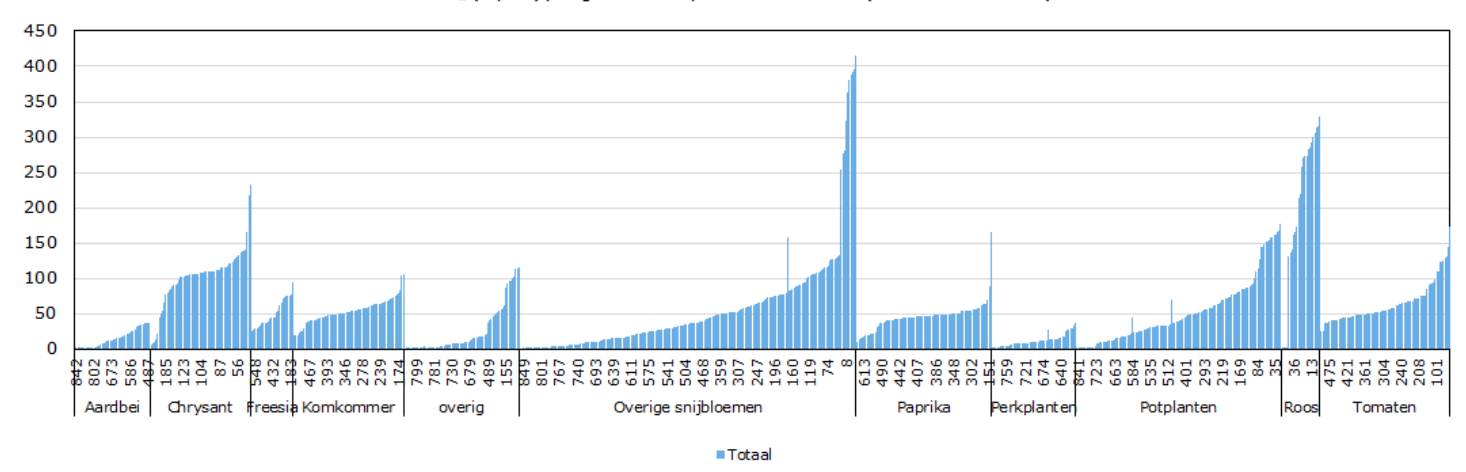

$\mathrm{CO}_{2}\left(\mathrm{eq} / \mathrm{m}^{2}\right)$ per gewas in de periode 2015-2017 (IPCC-methode)

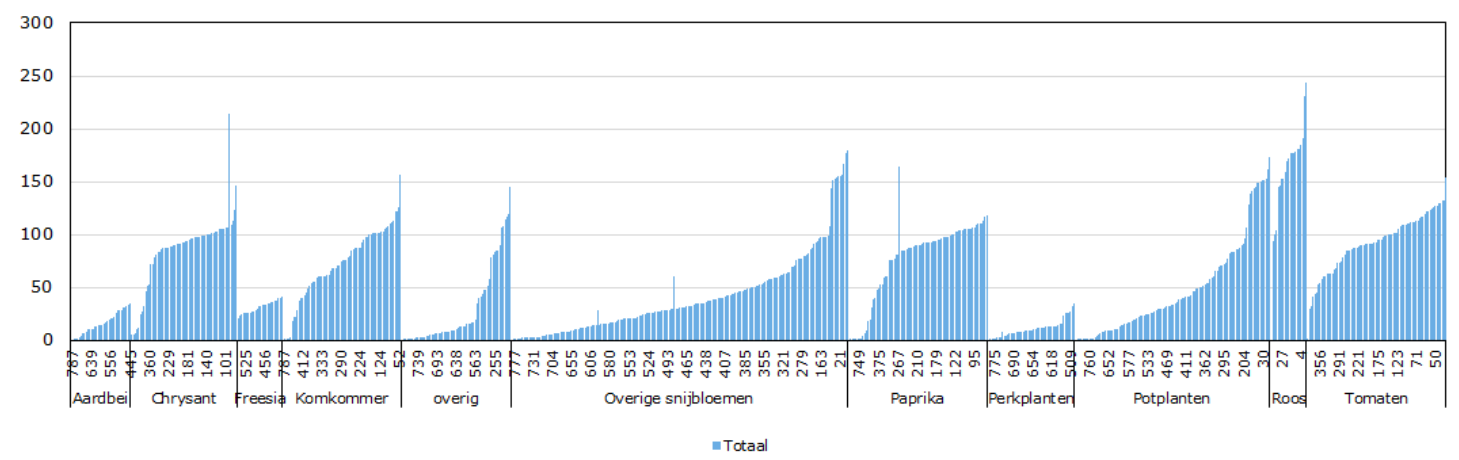

Figuur 3.14 $\mathrm{CO}_{2}$-emissie ( $\mathrm{kg} \mathrm{CO}$-eq. per $\mathrm{m}^{2}$ per jaar) ingedeeld naar gewas in de periode 20152017 volgens de attributiemethode, de substitutiemethode en de IPCC-methode (van boven naar beneden)

Figuur 3.14 laat zien dat de $\mathrm{CO}_{2}$-emissie volgens de substitutiemethode slechts weinig verschilt van die volgens de attributiemethode. Voor bedrijven die elektriciteit terugleveren, is de $\mathrm{CO}_{2}$-emissie bij de substitutiemethode lager dan bij de attributiemethode, afhankelijk van de hoeveelheid teruggeleverde 
elektriciteit. De $\mathrm{CO}_{2}$-emissie volgens de IPCC-methode ligt beduidend lager dan die volgens de andere twee bepalingsmethoden (let op de gewijzigde schaal voor de $y$-as), met uitzondering van bedrijven die zelf veel elektriciteit opwekken en deze bijna volledig terugleveren. In die gevallen is de $\mathrm{CO}_{2}-$ emissie volgens de substitutiemethode (veel) lager dan die volgens de IPCC-methode.

Het voorgaande wordt ook geillustreerd met het volgende voorbeeld.

Tabel 3.3 Vergelijking van de drie bepalingsmethoden voor broeikasgasemissies voor een voorbeeldsituatie

\begin{tabular}{|c|c|c|c|c|}
\hline & & Attributie & Substitutie & IPCC \\
\hline gasinput wkk & $\mathrm{m}^{3}$ & 450.000 & 450.000 & 450.000 \\
\hline gasinput ketel & $\mathrm{m}^{3}$ & 100.000 & 100.000 & 100.000 \\
\hline elektra inkoop & MWh & 200 & 200 & 200 \\
\hline wkk-elektraproductie & MWh & 1.583 & 1.583 & 1.583 \\
\hline nettowarmtegebruik & a.e. $\mathrm{m}^{3} / \mathrm{m}^{2}$ & 32,5 & 32,5 & 32,5 \\
\hline nettowarmtegebruik & $\mathrm{kWh} / \mathrm{m}^{2}$ & 286 & 286 & 286 \\
\hline ef $\mathrm{CO}_{2}$ gas $w k k+k e t e l$ & $\mathrm{~kg} \mathrm{CO}{ }_{2} \mathrm{eq} / \mathrm{m}^{3}$ & 1,791 & 1,791 & 1,791 \\
\hline ef $\mathrm{CH}_{4}$ gas wkk & $\mathrm{kg} \mathrm{CO}{ }_{2} \mathrm{eq} / \mathrm{m}^{3}$ & 0,418 & 0,418 & NVT \\
\hline ef $\mathrm{CO}_{2}$ eq. elektra inkoop & $\mathrm{kg} \mathrm{CO} 2 \mathrm{eq} / \mathrm{kWh}$ & 0,449 & 0,449 & NVT \\
\hline ef $\mathrm{CO}_{2}$ eq. elektra weggeleverd & $\mathrm{kg} \mathrm{CO} 2 \mathrm{eq} / \mathrm{kWh}$ & $-0,279$ & $-0,449$ & NVT \\
\hline emissies wkk & ton $\mathrm{CO}_{2}$ eq. & 994 & 994 & 806 \\
\hline emissies ketel & ton $\mathrm{CO}_{2}$ eq. & 179 & 179 & 179 \\
\hline emissies elektra inkoop & ton $\mathrm{CO}_{2}$ eq. & 90 & 90 & 0 \\
\hline
\end{tabular}

Uit tabel 3.3 volgt dat de bepalingsmethode van invloed is op de totale $\mathrm{CO}_{2}$-emissie en mede afhankelijk is van het bedrijf en de situatie van het energiebeheer (aankoop, opwekking en verkoop). Wel geeft de attributiemethode de situatie voor het individuele bedrijf beter weer en maakt deze methode beter inzichtelijk waar de mogelijkheden of aangrijpingspunten voor de ondernemer liggen om verder te verduurzamen op het terrein van energie. Bij de andere bepalingsmethoden is dit mede afhankelijk van invloeden van buitenaf (niet beïnvloedbaar door de ondernemer) en/of welke energiedragers worden meegenomen. Zo zal het terugleveren van elektriciteit aan het net bij de substitutiemethode afhankelijk zijn van de samenstelling van $\mathrm{CO}_{2}$-emissie van de in ieder land gebruikte elektriciteit. In Frankrijk wordt bijvoorbeeld relatief veel kernenergie gebruikt met geringe $\mathrm{CO}_{2}$-emissie, en in Duitsland worden kernenergie en bruinkool snel vervangen door wind- en zonnestroom met een geringe $\mathrm{CO}_{2}$-emissie. Ook in Nederland is een vergroening van de elektriciteitsproductie aan de gang. Dit heeft een sterke invloed op de aftrek van $\mathrm{CO}_{2}$-emissie bij teruglevering van elektriciteit aan het openbare net. 


\subsection{Indelingscategorieën voor broeikasgasemissies}

Uit paragraaf 3.2 is enerzijds duidelijk geworden welke factoren vooral van invloed zijn op de $\mathrm{CO}_{2}$ emissie op het bedrijf en anderzijds dat de bestanddelen van de $\mathrm{CO}_{2}$-emissie tussen de Informatienetbedrijven zeer divers zijn en afhankelijk zijn van de (energie)situatie op het bedrijf. Het netto-fossiele-elektriciteitsverbruik en het netto-fossiel warmteverbruik zijn de meest significante factoren voor de verklaring van de verschillen in broeikasgasemissie op de Informatienetbedrijven. Ook is duidelijk geworden welke factoren minder van invloed zijn en daardoor geen geschikte criteria lijken voor het ontwerpen van indelingscategorieën. Dit betreft het wel/niet belichten, wel/geen aanwezigheid van een wkk-installatie, het aantal (energie)schermen en de leeftijd van de kas. Deze factoren zijn impliciet in het netto-elektriciteitsverbruik en het nettowarmteverbruik meegenomen. Hierna zijn verschillende indelingscategorieën bekeken.

Indeling van Informatienetbedrijven in grootteklassen op basis van de hoogte van de $\mathrm{CO}_{2}$-emissie Als eerste zijn de Informatienetbedrijven ingedeeld naar klassen van broeikasgasemissies (zie figuur 3.15).

$\mathrm{kg} \mathrm{CO}$-eq. per $\mathrm{m}^{2}$ in 2017

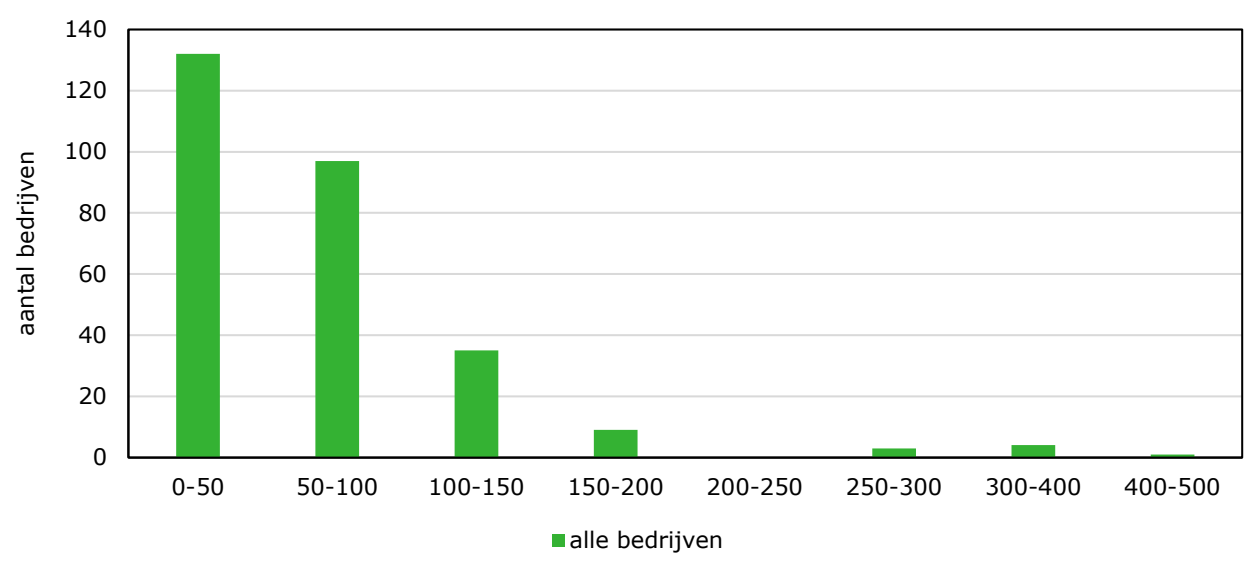

Figuur 3.15 Frequentieverdeling aantal bedrijven naar klassen van $\mathrm{CO}_{2}$-emissie $\left(\mathrm{kg} \mathrm{CO}_{2}\right.$-eq. per $\mathrm{m}^{2}$ per jaar per klasse van bedrijven) in 2017. Opmerking: Informatienetbedrijven zijn representatief qua gewassen en schaalgrootte maar niet qua energieverbruik

Op basis van de resultaten in de voorgaande grafieken is een klassebreedte gesteld van $50 \mathrm{~kg} \mathrm{CO}_{2}-$ equivalenten per $\mathrm{m}^{2}$ per jaar, waarbij boven de $300 \mathrm{~kg} \mathrm{CO}$-equivalenten per $\mathrm{m}^{2}$ stappen van $100 \mathrm{~kg}$ zijn aangehouden. Uit figuur 3.15 blijkt dat de frequentieverdeling van het aantal bedrijven naar de hoogte van de $\mathrm{CO}_{2}$-emissie in 2017 scheef is en geen normale verdeling laat zien. Dit verschijnsel trad ook op in 2015 en 2016. De meeste bedrijven hadden een $\mathrm{CO}_{2}$-emissie onder de $100 \mathrm{~kg} \mathrm{CO}_{2}$ equivalenten per $\mathrm{m}^{2}$. Een $\mathrm{CO}_{2}$-emissie tussen 200 en $300 \mathrm{~kg} \mathrm{CO}$-equivalenten per $\mathrm{m}^{2}$ kwam weinig voor op de bedrijven met bedekte teelt. Daarentegen zijn er wat meer bedrijven met een $\mathrm{CO}_{2}$-emissie tussen 300 en $500 \mathrm{~kg} \mathrm{CO}_{2}$-equivalenten per $\mathrm{m}^{2}$. Dit laatste hangt sterk samen met de hogere intensiteit van belichting op de bedrijven (belichtingsniveau en -duur).

Indeling van Informatienetbedrijven in kwartielen en kwintielen op basis van de omvang van de $\mathrm{CO}_{2}-$ emissie

Hierna zijn de Informatienetbedrijven ingedeeld in kwartielen en kwintielen naar de omvang van de $\mathrm{CO}_{2}$-emissie (zie tabel 3.4) en enkele relevante invloedfactoren. Dit is gebeurd met behulp van de statistieksoftware SPSS. Bij kwartielen zijn de bedrijven verdeeld in vier even grote groepen bedrijven gerangschikt naar de omvang van de $\mathrm{CO}_{2}$-emissie $(0-25 \%, 25-50 \%, 50-75 \%$ en $75-100 \%)$. Bij de indeling volgens kwintielen zijn de bedrijven verdeeld in vijf even grote groepen bedrijven (0-20\%, $20-40 \%, 40-60 \%, 60-80 \%$ en $80-100 \%$ ). 
Tabel 3.4 Indeling van Informatienetbedrijven over alle jaren naar de omvang van de $\mathrm{CO}_{2}$-emissie in kwartielen en kwintielen en de bijbehorende niveaus van enkele invloedfactoren (gemiddeld per bedrijf)

Indeling van bedrijven naar hoogte $\mathrm{CO}_{2}$-emissie in kwartielen

\begin{tabular}{|c|c|c|c|c|c|c|}
\hline & & \multicolumn{4}{|c|}{ Klassen } & \multirow[t]{2}{*}{ Totaal } \\
\hline & & 1 & 2 & 3 & 4 & \\
\hline & aantal & 213 & 214 & 214 & 213 & 854 \\
\hline $\mathrm{CO}_{2}$-emissie & gem. & 6,40 & 31,84 & 69,06 & 138,33 & 61,38 \\
\hline $\mathrm{Gas} / \mathrm{m}^{2}$ & gem. & 2,74 & 13,97 & 38,87 & 59,75 & 28,83 \\
\hline nettowarmte $\mathrm{kWh} / \mathrm{m}^{2}$ & gem. & 29,09 & 144,09 & 263,97 & 354,17 & 197,84 \\
\hline netto-elek. kWh/m² & gem. & 2,89 & 11,01 & 26,90 & 151,92 & 48,11 \\
\hline belichting $=1=\mathrm{ja}$ & gem. & 0,11 & 0,24 & 0,31 & 0,81 & 0,37 \\
\hline met $W K=1$ & gem. & 0,02 & 0,09 & 0,60 & 0,88 & 0,40 \\
\hline bouwjaar & gem. & 0,25 & 0,25 & 0,51 & 0,59 & 0,40 \\
\hline aantal schermen & gem. & 0,22 & 0,49 & 0,50 & 0,44 & 0,41 \\
\hline Aardbei $=j a=1$ & gem. & 0,12 & 0,09 & 0,00 & 0,00 & 0,05 \\
\hline Chrysant=ja = 1 & gem. & 0,02 & 0,01 & 0,01 & 0,24 & 0,07 \\
\hline Freesia $=j a=1$ & gem. & 0,00 & 0,07 & 0,05 & 0,00 & 0,03 \\
\hline Komkommer =ja=1 & gem. & 0,00 & 0,06 & 0,20 & 0,06 & 0,08 \\
\hline Overig=ja= 1 & gem. & 0,22 & 0,06 & 0,01 & 0,05 & 0,09 \\
\hline Overige snijbloemen $=j a=1$ & gem. & 0,27 & 0,33 & 0,18 & 0,20 & 0,24 \\
\hline Paprika $=j a=1$ & gem. & 0,02 & 0,07 & 0,26 & 0,04 & 0,10 \\
\hline Perkplanten $=j a=1$ & gem. & 0,20 & 0,05 & 0,00 & 0,00 & 0,06 \\
\hline Potplanten $=\mathrm{ja}=1$ & gem. & 0,13 & 0,24 & 0,10 & 0,14 & 0,15 \\
\hline Roos $=j a=1$ & gem. & 0,02 & 0,00 & 0,00 & 0,09 & 0,03 \\
\hline Tomaten $=\mathrm{ja}=1$ & gem. & 0,00 & 0,02 & 0,18 & 0,17 & 0,09 \\
\hline
\end{tabular}

Indeling van bedrijven naar hoogte $\mathrm{CO}_{2}$-emissie in kwintielen

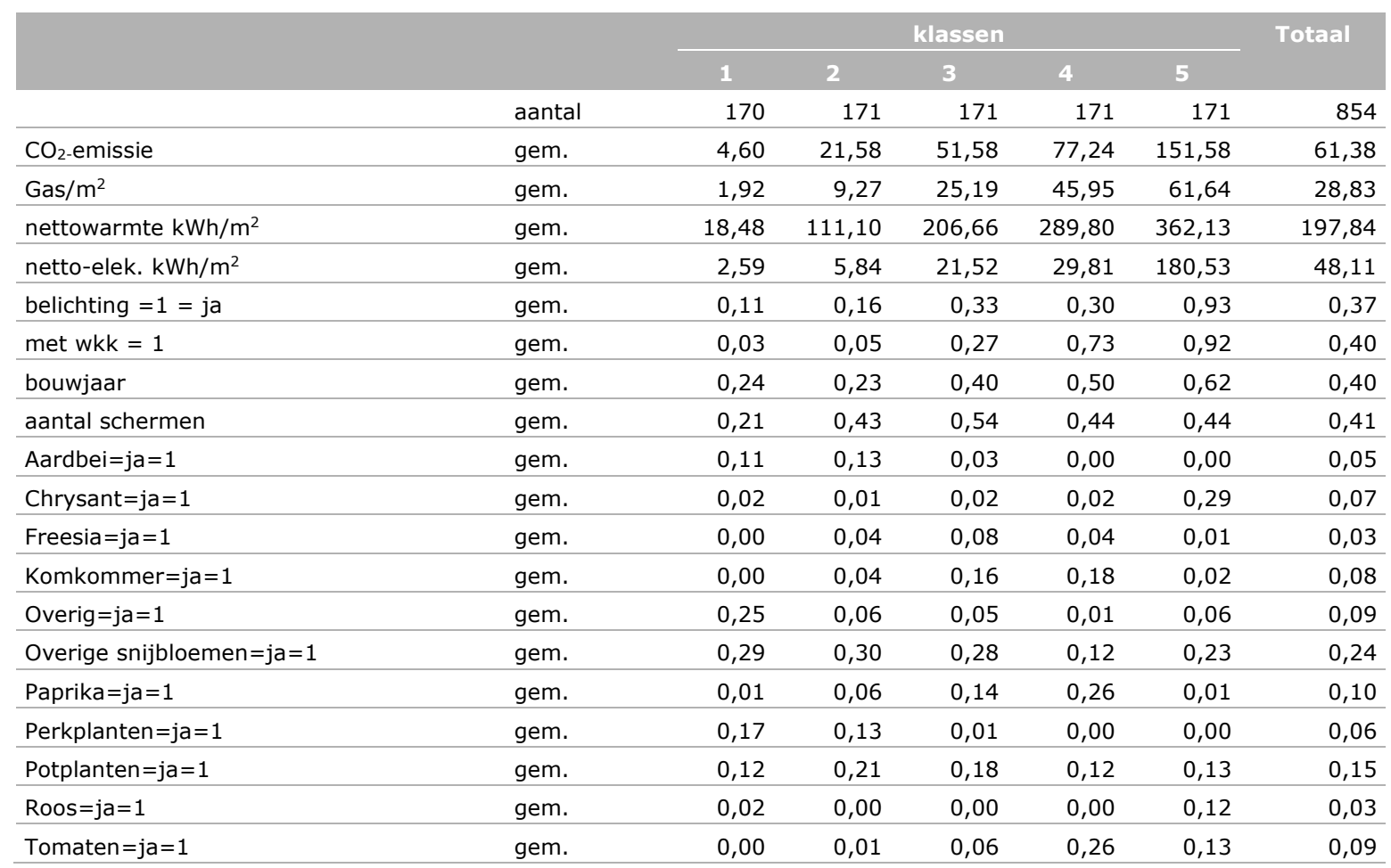


Uit tabel 3.4 blijkt dat zowel bij een indeling volgens kwartielen als bij een indeling volgens kwintielen de toename van de omvang van de $\mathrm{CO}_{2}$-emissie samengaat met een hogere mate van belichting en de aanwezigheid van wkk-installaties. Ook blijken de bedrijven in de hoogste kwartielen en kwintielen over jongere en modernere kassen te beschikken. Dit verschil is niet of nauwelijks aanwezig tussen het eerste en tweede kwartiel (beiden 0,25$)$ en het eerste en tweede kwintiel $(0,24$ respectievelijk $0,23)$.

Het gemiddelde aantal schermen op de bedrijven is, behalve in het laagste kwartiel en laagste kwintiel, vrijwel gelijk en geen grote factor voor verschillen in $\mathrm{CO}_{2}$-emissie. Opvallend is dat het hoogste kwartiel en het hoogste kwintiel een lager gemiddeld aantal schermen per bedrijf laat zien dan het op een na hoogste kwartiel en kwintiel. Waarschijnlijk houdt dit verband met nieuwere schermen, die energiezuiniger zijn en daardoor beter in het teeltconcept 'Het Nieuwe Telen' (HNT) passen. Een andere mogelijkheid is dat de belichting zoveel warmte afgeeft dat er een warmteoverschot in de kas ontstaat, wat nadelig kan zijn voor het gewas.

Tabel 3.4 laat nogmaals zien dat het aanzienlijk hogere netto-elektriciteitsverbruik in het hoogste kwartiel en het hoogste kwintiel ten gevolge van belichting de omvang van de gemiddelde $\mathrm{CO}_{2}$-emissie per bedrijf sterk bepaalt.

Bedrijven in het laagste kwartiel en het laagste kwintiel wijken sterk af van de andere kwartielen/kwintielen met betrekking tot de $\mathrm{CO}_{2}$-emissie en de hoogte van de invloedfactoren. Deze groep bedrijven teelt overwegend energie-extensief. Voor deze groep bedrijven zijn energie- en daarmee $\mathrm{CO}_{2}$-besparende maatregelen moeilijk economisch rond te rekenen, omdat de bespaarde gaskosten veelal niet opwegen tegen de extra kosten van deze maatregelen.

De grenswaarden van de kwartielen en kwintielen zoals die eruit komen te zien op basis van de gemiddelde waarden voor de $\mathrm{CO}_{2}$-emissie per bedrijf uit tabel 3.4 zijn weergegeven in tabel 3.5. De grenswaarde is hierbij geschat op basis van de verdeling van de $\mathrm{CO}_{2}$-emissie over de bedrijven in de periode 2015-2017. Deze indeling kan als handvat worden gezien voor het indelen van de Informatienetbedrijven. Voor de On the Way to PlanetProof-bedrijven dient deze exercitie echter op basis van de data van de On the Way to PlanetProof-bedrijven te geschieden, omdat de samenstelling van deze bedrijven niet geheel identiek is aan de samenstelling van de Informatienetbedrijven. De spreiding in energieverbruik is op de Informatienetbedrijven groter dan op de SMK-bedrijven, omdat de SMK-bedrijven alle gecertificeerd zijn en daardoor gemiddeld hoger scoren op duurzaamheid.

Tabel 3.5 Geschatte grenswaarde voor $\mathrm{CO}_{2}$-emissie ( $\mathrm{kg} \mathrm{CO}_{2}$-eq. per $\mathrm{m}^{2}$ per bedrijf) per kwartiel en kwintiel $^{1}$

Grenswaarden voor $\mathrm{CO}_{2}$-emissie per bedrijf bij een kwartielindeling

$\begin{array}{lllll} & 1 & 2 & 3 & 4 \\ \text { Totaal } \mathrm{CO}_{2}\left(\mathrm{~kg} \mathrm{CO} \text {-eq. } / \mathrm{m}^{2}\right) & 0-25 & 25-60 & 60-105 & >105\end{array}$

Grenswaarden voor $\mathrm{CO}_{2}$-emissie per bedrijf bij een kwintielindeling

$\begin{array}{ccccc}\text { Totaal } \mathrm{CO}_{2}\left(\mathrm{~kg} \mathrm{CO}-\mathrm{eq} . / \mathrm{m}^{2}\right) & 0-20 & 20-45 & 45-70 & 70-110 \\ 1 \text { Voorbeeldgewas kwintielen: 1) perkplanten, 2) freesia, 3) paprika, 4) komkommer en 5) roos en chrysant. }\end{array}$

Bij tabel 3.5 staat de indeling los van het gewas en hangt de $\mathrm{CO}_{2}$-emissie samen met de belangrijkste invloedfactoren (netto-elektriciteitsverbruik en nettowarmteverbruik). Daarin spelen belichting, wkkinstallatie en leeftijd van de kassen een rol, maar niet als aparte factor.

Indeling van de Informatienetbedrijven in kwartielen op basis van de $\mathrm{CO}_{2}$-emissie en haar bestanddelen

Om meer vat te krijgen op een mogelijke indeling van de bedrijven naar de hoogte van de $\mathrm{CO}_{2}$ emissie zijn de Informatienetbedrijven voor alle jaren samen en voor elk jaar afzonderlijk ingedeeld in 
kwartielen, waarbij ook de bestanddelen van de $\mathrm{CO}_{2}$-emissie zijn weergegeven. In figuur 3.16 zijn de bedrijven ingedeeld in kwartielen ten aanzien van de broeikasgasemissies en is voor elk kwartiel een gemiddelde weergegeven van de bestanddelen.

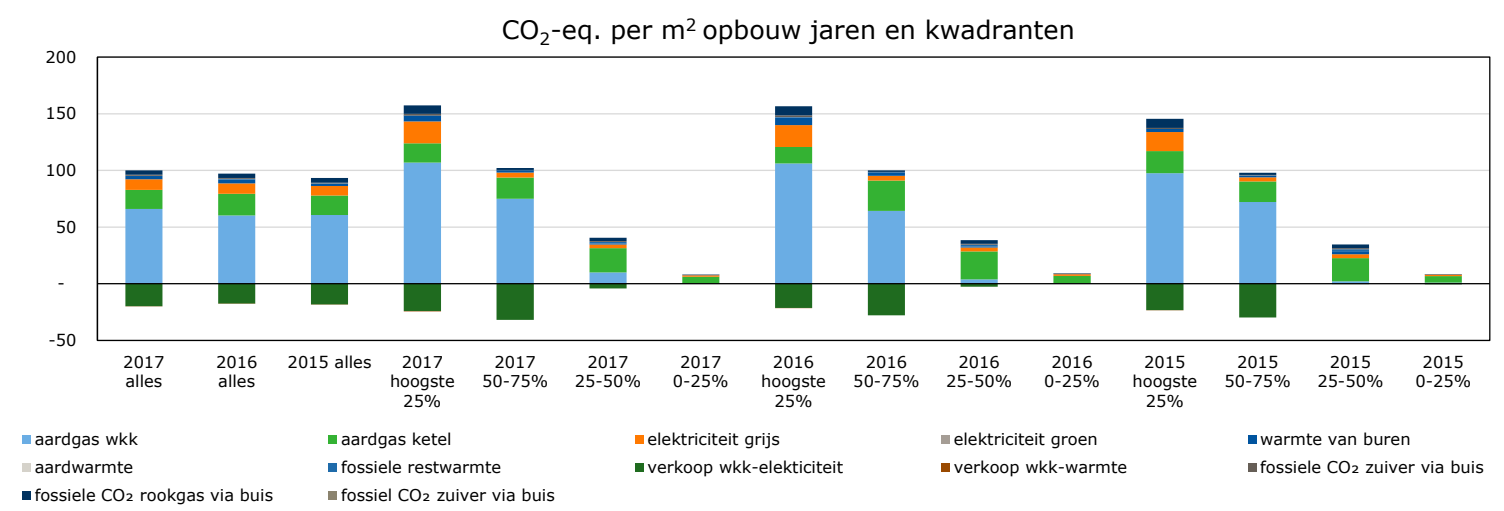

Figuur 3.16 Verdeling van de Informatienetbedrijven in kwartielen van $\mathrm{CO}_{2}$-emissie ( $\mathrm{kg} \mathrm{CO}_{2}$-eq. per $m^{2}$ per jaar voor een gemiddeld bedrijf) in 2015, 2016 en 2017 en uitgesplitst naar de bestanddelen van de $\mathrm{CO}_{2}$-emissie. Opmerking: in deze figuur moet de aankoop van $\mathrm{CO}_{2}$ (via weg en via buis) buiten beschouwing worden gelaten.

Uit figuur 3.16 blijkt in eerste instantie dat de gemiddelde $\mathrm{CO}_{2}$-emissie in de loop der jaren iets is toegenomen. Zowel de bovengrens als de ondergrens is iets gestegen (zie linker drie kolommen in figuur 3.16). Ook blijkt dat het verbruik van aardgas voor de wkk het overgrote deel van de $\mathrm{CO}_{2}$ emissie bepaalt, gevolgd door aardgas voor de ketel. Ook volgt uit figuur 3.16 dat circa 20 kg $\mathrm{CO}_{2}-$ equivalenten per $\mathrm{m}^{2}$ per jaar per gemiddeld bedrijf samenhangt met de verkoop van elektriciteit. Dit moet nog worden afgetrokken van de bruto- $\mathrm{CO}_{2}$-emissie door inkoop van gas, elektriciteit, warmte en $\mathrm{CO}_{2}$, dus exclusief de (negatieve) $\mathrm{CO}_{2}$-emissie gerelateerd aan de verkoop van elektriciteit en warmte. In de kolommen daarnaast is de $\mathrm{CO}_{2}$-emissie weergeven voor de kwartielen per jaar. Dit levert het inzicht op dat de bruto- $\mathrm{CO}_{2}$-emissie op de bedrijven in het derde en vierde kwartiel (50-75\% respectievelijk 75-100\%) vooral is bepaald door het gasverbruik voor de wkk en ketel en de inkoop van grijze stroom. Bij deze twee kwartielen is de $\mathrm{CO}_{2}$-emissie ondanks de verkoop van elektriciteit hoog, met name in het kwartiel 50-75\%. Bedrijven in dit kwartiel belichten minder intensief en verkopen relatief meer van de door de wkk opgewekte elektriciteit.

In de eerste twee kwartielen (0-25\% en $25-50 \%$ ) is het bedrijf overwegend verwarmd met de ketel. In het tweede kwartiel is nog sprake van $\mathrm{CO}_{2}$-emissie gerelateerd aan de wkk voor zowel productie van elektriciteit en warmte als verkoop van elektriciteit. In het eerste kwartiel is de totale $\mathrm{CO}_{2}$-emissie aanzienlijk lager dan in de andere drie kwartielen. De bedrijven in dit kwartiel telen extensief door een lage warmte- en elektriciteitsbehoefte.

Op basis van figuur 3.16 is ook een indeling te maken naar de hoogte van de $\mathrm{CO}_{2}$-emissie, rekening houdend met de negatieve $\mathrm{CO}_{2}$-emissie door de verkoop van elektriciteit en warmte. De indeling zou er dan uit kunnen zien zoals weergegeven in tabel 3.6. De grenswaarden voor de vier klassen zijn geschat. 
Tabel 3.6 Geschatte grenswaarde voor $\mathrm{CO}_{2}$-emissie ( $\mathrm{kg} \mathrm{CO}_{2}$-eq. per $\mathrm{m}^{2}$ per bedrijf) voor vier klassen $^{1}$

Grenswaarde voor $\mathrm{CO}_{2}$-emissie per bedrijf

Totaal $\mathrm{CO}_{2}\left(\mathrm{~kg} \mathrm{CO}-\mathrm{eq} . / \mathrm{m}^{2}\right)$
$\begin{aligned} & 1 \\ & \left.{ }^{1} \text { Kenmerken bedrijven per categorie: } 1\right) \text { lage warmtebehoefte, geen belichting en geen wkk, 2) beperkte warmtebehoefte, belichting en wkk }\end{aligned}$
aanwezig op beperkt aantal bedrijven, 3) geen belichting en wel wkk (met levering elektra aan derden) en 4) intensieve belichting, wkk aanwezig
en levering elektra aan derden.

Ook in tabel 3.6 staat de indeling los van het gewas en hangt de $\mathrm{CO}_{2}$-emissie samen met de belangrijkste invloedfactoren (netto-elektriciteitsverbruik en nettowarmteverbruik). Ook daarin spelen belichting, wkk-installatie en leeftijd van de kas een rol, maar niet als aparte factor. Bij de indeling in vier klassen is duidelijk dat de eerste twee grootteklassen nauwelijks of geen wkk hebben en er ook weinig tot geen elektriciteit wordt verkocht. De $\mathrm{CO}_{2}$-emissie wordt in deze situaties bepaald door het gasverbruik voor de ketel en de inkoop van grijze stroom. In de derde grootteklasse (50-100 kg $\mathrm{CO}_{2}-$ equivalenten per $\mathrm{m}^{2}$ per jaar per bedrijf) is in hoge mate een wkk aanwezig, maar is er ook relatief veel verkoop van door de wkk opgewekte elektriciteit omdat er een grote groep bedrijven is die niet belicht. Bedrijven in de vierde grootteklasse produceren intensief met belichting en wkk en verkopen relatief minder elektriciteit.

Indeling op basis van de regressievergelijking met de twee meest significante variabelen

In paragraaf 3.2.10 leidt de regressieanalyse tot twee belangrijke verklarende factoren voor de $\mathrm{CO}_{2}$ emissie, namelijk: het netto-elektriciteitsverbruik (in $\mathrm{kWh} / \mathrm{m}^{2}$ ) en het gasverbruik (in $\mathrm{m}^{3}$ per $\mathrm{m}^{2}$ ).

De regressievergelijking voor de Informatienetbedrijven in het vergelijkbare jaar 2017 is als volgt:

$$
\begin{aligned}
& Z=9,147+0,372 * X+1,186 * Y \text {, } \\
& R^{2}=0,957 \text {, significantie beide coëfficiënten } p \text {-waarde }=0,000 \\
& \text { waarbij: } \quad \mathrm{Z}=\mathrm{CO}_{2} \text {-emissie }\left(\mathrm{kg} \mathrm{CO} \text {-eq. per } \mathrm{m}^{2}\right. \text { per jaar); } \\
& \mathrm{X}=\text { netto-elektriciteitsverbruik ( } \mathrm{kWh} \text { per } \mathrm{m}^{2} \text { per jaar); } \\
& \mathrm{Y}=\text { gasverbruik }\left(\mathrm{m}^{3} \text { per } \mathrm{m}^{2} \text { per jaar }\right) \text {. }
\end{aligned}
$$

In figuur 3.17 is dit geïllustreerd.

Figuur 3.17 laat zien dat de $\mathrm{CO}_{2}$-emissie op basis van de regressievergelijking voor de $20 \%$ bedrijven met de hoogste $\mathrm{CO}_{2}$-emissie sterk wordt overschat, bij de volgende $30 \%$ minder wordt overschat en bij de overige bedrijven goed wordt ingeschat. Dit betekent dat de bedrijven in de linkerhelft van de $\mathrm{x}$-as bij een indelingssysteem dat mede op de regressievergelijking is gebaseerd een wat hogere $\mathrm{CO}_{2}-$ emissie krijgen toebedeeld, met andere woorden een minder vergaande streefwaarde opgelegd zouden krijgen opgelegd. De groep lijkt uit drie subgroepen te bestaan, waarbij wkk-gebruik en mate van belichting een rol spelen. 


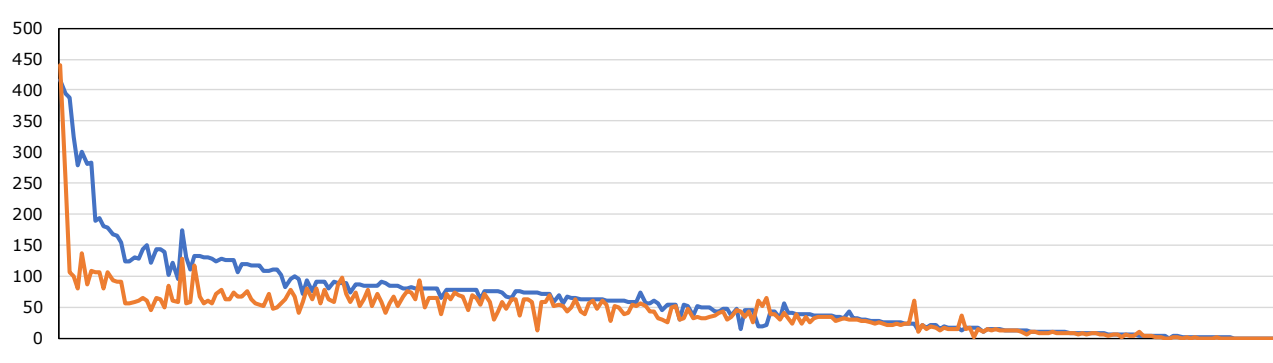

Figuur 3.17 $\mathrm{CO}_{2}$-emissie ( $\mathrm{kg} \mathrm{CO}$-eq. per $\mathrm{m}^{2}$ per jaar per bedrijf) op basis van werkelijk nettoelektriciteitsverbruik ( $k W h$ per $\mathrm{m}^{2}$ ) en gasverbruik $\left(\mathrm{m}^{3}\right.$ per $\mathrm{m}^{2}$ ) in 2017 en berekend met de regressievergelijking (bron: Bedrijveninformatienet 2017)

De meest extreme bedrijven qua $\mathrm{CO}_{2}$-emissie (circa drie bedrijven, links op de $\mathrm{x}$-as) kunnen niet uit de Informatienetdataset worden verwijderd, omdat de emissie is gebaseerd op reële situaties. Er is, na nadere analyse, geen directe aanleiding om deze bedrijven uit de dataset te verwijderen als uitbijters. Op de hierna vermelde indeling heeft dit niet of nauwelijks invloed.

Bij het onderstaande voorstel voor een alternatieve categorie-indeling is rekening gehouden met de overschatting in figuur 3.17. Hierbij is de regressievergelijking als vertrekpunt genomen voor het indelen van On the Way to PlanetProof-bedrijven. Daarbij is verondersteld dat circa $50 \%$ van de On the Way to PlanetProof-bedrijven minimaal aan de 'norm voor broeikasgassen' behoort te voldoen. Daarnaast wordt voorgesteld dat de $25 \%$ van de On the Way to PlanetProof-bedrijven met de laagste broeikasemissies geen aanvullende maatregelen meer hoeft te nemen voor de komende $X$ jaar (aantal jaar door SMK te bepalen). Op basis van de regressievergelijking volgt hieruit dat de grenswaarde uitgedrukt in $\mathrm{kg} \mathrm{CO}$-equivalenten per $\mathrm{m}^{2}$ per jaar per bedrijf voor $50 \%$ en $75 \%$ van het aantal On the Way to PlanetProof-deelnemers op circa 25 respectievelijk 1 ligt. Met andere woorden: bedrijven met een emissie van minder dan circa $25 \mathrm{~kg} \mathrm{CO}$-equivalenten per $\mathrm{m}^{2}$ per jaar per bedrijf voldoen aan de norm voor broeikasgasemissies. Bedrijven binnen deze categorie die minder dan circa $1 \mathrm{~kg} \mathrm{CO}_{2}-$ equivalenten per $\mathrm{m}^{2}$ per jaar per bedrijf uitstoten, kunnen vrijgesteld worden van aanvullende duurzaamheidsmaatregelen op energiegebied gedurende een door SMK nader te bepalen periode.

Opmerking: bovenstaande grenswaarden zijn bepaald op basis van de Informatienetbedrijven. Voor On the Way to PlanetProof-bedrijven moeten de grenswaarden op basis van de SMK-data worden vastgesteld. Deze liggen zeer waarschijnlijk lager, omdat de bandbreedte in de met de regressievergelijking berekende $\mathrm{CO}_{2}$-emissie van de On the Way to PlanetProof-bedrijven smaller is dan die van de Informatienetbedrijven.

Geen indeling, maar dezelfde prestatie-eis voor alle bedrijven

In dit geval zijn alle bedrijven gelijkwaardig zonder rekening te houden met de situatie waarin de bedrijven verkeren. Met andere woorden: er is geen rekening gehouden met het gewas, wel of geen belichting, wel of geen aanwezigheid van een wkk-installatie of het aantal schermen. Elk bedrijf wordt dezelfde prestatie-eis opgelegd om tot verdere verduurzaming te komen ten aanzien van de $\mathrm{CO}_{2}$ emissie. Men kan hierbij denken aan een eis van bijvoorbeeld $2 \% \mathrm{CO}_{2}$-emissiereductie per jaar. Deze eis geldt dan voor elk bedrijf, of het nu weinig of veel $\mathrm{CO}_{2}$-emissie teweegbrengt. Voor bedrijven die al zeer duurzaam produceren en een lage $\mathrm{CO}_{2}$-emissie laten zien, is de absolute reductie dan ook klein. Voor bedrijven die een hoge(re) $\mathrm{CO}_{2}$-emissie veroorzaken is de absolute reductie dan groter of groot, afhankelijk van de energiesituatie op het bedrijf. Deze insteek lijkt fair, omdat ieder bedrijf gelijk wordt behandeld. Hierbij wordt geen rekening gehouden met het feit dat het voor een bedrijf dat al veel energie heeft bespaard relatief moeilijker zal zijn om nog verder op fossiele energie te besparen. 
Als variant is denkbaar dat de jaarlijkse $\mathrm{CO}_{2}$-emissie niet met bijvoorbeeld $2 \%$ wordt gereduceerd, maar met veelvouden daarvan, afhankelijk van de periode (in jaren). Bijvoorbeeld $6 \%$ reductie binnen drie jaar of $10 \%$ in vijf jaar tijd. Dit laatste sluit beter aan bij het investeringsritme van de bedrijven.

\subsection{Additionele monitoring van data op de On the Way to PlanetProof-bedrijven voor de indelingscategorieën}

Op basis van de analyse van de energiedata van de Informatienetbedrijven en de daaruit voorgestelde indelingssystemen is geen additionele monitoring van energiedata op de On the Way to PlanetProofbedrijven noodzakelijk.

Wel is te overwegen om de aankoop van $\mathrm{CO}_{2}$ op de On the Way to PlanetProof-bedrijven mee te nemen in de rekenmodule voor broeikasgasemissie en op dezelfde wijze te behandelen als de inkoop van gas, warmte en elektriciteit (een soort volledige input/output-tabel). Hierbij moet ook nader worden gekeken naar de emissiefactor van het extern ingekochte $\mathrm{CO}_{2}$ (fossiel of duurzaam geproduceerd). Normaliter is het externe $\mathrm{CO}_{2}$ al toegerekend aan de leverancier (nietglastuinbouwbedrijf) (BSI, 2011a; BSI, 2011b; Scholten en Blonk, 2011). Daarnaast moet de $\mathrm{CO}_{2}{ }^{-}$ emissie gerelateerd aan het transporteren en comprimeren van $\mathrm{CO}_{2}$ wel worden toegerekend aan de glastuinbouw. Emissiefactoren voor deze $\mathrm{CO}_{2}$-emissieroutes zijn nog niet uitgekristalliseerd, maar wel in ontwikkeling. 


\section{$4 \quad$ Discussie en aanbevelingen}

\subsection{Discussie}

Informatienetbedrijven en On the Way to PlanetProof-bedrijven

In de studie is het Bedrijveninformatienet van Wageningen Economic Research gebruikt om de analyse van het energieverbruik, de rol van de invloedfactoren en de daaraan gerelateerde $\mathrm{CO}_{2}$-emissie te bepalen. Hierbij is gebruikgemaakt van de rekenmodule voor broeikasgasemissie. De On the Way to PlanetProof-bedrijven scoren naar verwachting gemiddeld beter op duurzaamheid dan de Informatienetbedrijven, omdat de SMK-bedrijven voor duurzaamheid zijn gecertificeerd. Ook bij de Informatienetbedrijven zal een aantal door SMK zijn gecertificeerd, maar niet allemaal.

Van de Informatienetbedrijven zijn meer energiedata en aan energie gerelateerde data bekend. Hierdoor is meer inzicht verkregen in variatie in de energiesituatie op de bedrijven en in de relaties tussen enerzijds de $\mathrm{CO}_{2}$-emissie en anderzijds het energieverbruik en de teelt- en bedrijfskenmerken. Daarnaast zijn er gegevens over een groter aantal jaren beschikbaar voor analyse, waaruit voor deze analyse de jaren 2015, 2016 en 2017 zijn gebruikt.

Ten slotte is op de Informatienetbedrijven informatie aanwezig over extern aangekocht $\mathrm{CO}_{2}$. Deze informatie is niet beschikbaar in de SMK-dataset voor bedrijven met bedekte teelt. Kortom, het Bedrijveninformatienet is een geschikte dataset gebleken om de vraag van SMK te kunnen beantwoorden, ook al zijn de Informatienetbedrijven niet representatief voor het energieverbruik in de glastuinbouw omdat energie niet meegenomen is bij het trekken van de bedrijven uit de totale populatie van glastuinbouwbedrijven in Nederland.

Verschillen in $\mathrm{CO}_{2}$-emisssie tussen de verschillende bepalingsmethoden (attributie, substitutie en IPCC)

In deze studie is de attributiemethode gehanteerd om de $\mathrm{CO}_{2}$-emissie van de primaire productiebedrijven te bepalen. Bij de substitutiemethode wordt levering van elektriciteit en warmte aan derden zwaarder gewaardeerd in emissietermen dan bij de attributiemethode, zodat de netto $\mathrm{CO}_{2}-$ emissie per saldo lager is voor de primaire glastuinbouwbedrijven. Dit geldt niet voor bedrijven die geen elektra en/of warmte aan derden leveren.

Bij de IPCC-methode wordt enkel het gasverbruik op het bedrijf meegenomen bij het bepalen van de $\mathrm{CO}_{2}$-emissie. In dat geval is de $\mathrm{CO}_{2}$-emissie bij de meeste bedrijven lager dan volgens de voorgaande twee methoden, behalve bij bedrijven die (relatief) veel energie (met name elektriciteit) wegleveren. Dit laatste komt doordat de emissie gerelateerd aan de productie van de weggeleverde elektriciteit volledig meetelt in de $\mathrm{CO}_{2}$-emissie van het primaire bedrijf.

De keuze voor een van de drie methoden is niet alleen een inhoudelijke, maar ook een politieke. De keuze voor een van de indelingscategorieën en de inherente normering voor broeikasgasemissies valt onder de verantwoordelijkheid van SMK.

Monitoring extern $\mathrm{CO}_{2}$

In overleg met SMK is tijdens het onderzoekstraject besloten om extern ingekocht $\mathrm{CO}_{2}$ wel mee te nemen in het raamwerk van de $\mathrm{CO}_{2}$-emissiebepaling, maar is de emissiefactor op nul gesteld. Met andere woorden: de aankoop van $\mathrm{CO}_{2}$ telt uiteindelijk niet mee in de totale $\mathrm{CO}_{2}$-emissie. De aankoop en verkoop van $\mathrm{CO}_{2}$ door het glastuinbouwbedrijf is momenteel geen onderdeel van de rekenmodule voor broeikasgasemissie, maar kan door SMK in overweging worden genomen.

Mocht aankoop van $\mathrm{CO}_{2}$ alsnog in de rekenmodule voor broeikasgasemissie worden opgenomen, dan dient aandacht te worden besteed aan de emissiefactoren die samenhangen met de aankoop van $\mathrm{CO}_{2}$. 
In de $\mathrm{CO}_{2}$-emissiebepaling zou dan ook rekening moeten worden gehouden met de $\mathrm{CO}_{2}$-emissie gerelateerd aan het transporteren en comprimeren van het rookgas $-\mathrm{CO}_{2}$ aan de glastuinbouw.

Variatie in energieverbruik en $\mathrm{CO}_{2}$-emissie

De cijfers uit het Bedrijveninformatienet voor bedrijven met bedekte teelt laten zien dat de variatie zeer groot is en wordt veroorzaakt door verschillende factoren. Behalve de energie benodigd voor verwarming en belichting zijn er ook andere verbruiks- en emissiebepalende factoren, zoals gewastype, aanwezigheid van een wkk-installatie, gebruik van rest- of aardwarmte, collectieve of clusterinitiatieven, aantal schermen en leeftijd van de kassen. Tussen jaren bestaan verschillen in buitenklimaat (lichtsom en aantal graaddagen) en daardoor verschillen in energieverbruik en $\mathrm{CO}_{2}$ emissie. Wel kan worden geconcludeerd dat de verschillen in netto-energieverbruik in hoge mate de verschillen in $\mathrm{CO}_{2}$-emissie verklaren.

Verschillen in energiemanagement (als onderdeel van de bedrijfsvoering) zijn niet onderzocht en dus moeilijk te duiden. Het is bekend dat de bedrijfsvoering mede bepalend is voor het uiteindelijke energieverbruik en de $\mathrm{CO}_{2}$-emissie, kijkend naar de praktijkervaringen met het teeltconcept 'Het Nieuwe Telen'. ${ }^{4}$ Door managementmaatregelen is op de bedrijven nog ruimte aanwezig om het energieverbruik en de $\mathrm{CO}_{2}$-emissie terug te dringen. Deze maatregelen zijn veelal uit te voeren met lagere investeringen en lagere kosten.

\section{Herijking indelingscategorie}

In de volgende paragraaf is op basis van de analyse van het energieverbruik, de $\mathrm{CO}_{2}$-emissie en de mogelijke indelingscategorieën een voorstel opgesteld om bedrijven in groepen in te delen. Afhankelijk van welk indelingssysteem door SMK wordt gekozen, is de vraag te stellen of en op welke termijn een herijking zou moeten plaatsvinden. Dit betreft de indelingen met grenswaarden op basis van de met de rekenmodule voor broeikasgasemissie berekende $\mathrm{CO}_{2}$-emissies. De tijd en inzichten schrijden voort en daarmee ook de prestaties ten aanzien van energieverbruik en $\mathrm{CO}_{2}$-emissie op de bedrijven. In dat verband is het wenselijk de analyse regelmatig opnieuw uit te voeren ten behoeve van de stimulering van On the Way to PlanetProof-bedrijven om te besparen op fossiele energie. De herijking zou tweeof driejaarlijks kunnen plaatsvinden, waarbij rekening moet worden gehouden met het investeringsritme van de bedrijven en de ontwikkelingen ten aanzien van energie-innovaties en energiebesparing. Voor de energieprestatie-eis (bijvoorbeeld $2 \% \mathrm{CO}_{2}$-emissiereductie per jaar) is een herijking niet nodig.

\section{Indelingsvoorstel binnen SMK}

In aanloop naar deze studie is door SMK in samenwerking met Kool Analyse \& Advies een conceptuele indelingssystematiek opgezet, die is gericht op het bepalen van de $\mathrm{CO}_{2}$-emissieruimte (in $\mathrm{kg} \mathrm{CO}_{2}$ equivalenten per $\mathrm{m}^{2}$ ) van de On the Way to PlanetProof-bedrijven voor verwarming en belichting. In het kort komt het erop neer dat de ruimte voor $\mathrm{CO}_{2}$-emissie afhankelijk is van de teelttemperatuur (een gewas met een hogere gemiddelde teelttemperatuur krijgt ruimte voor een hoger nettowarmteverbruik) en de mate van belichting (bepaald door belichtingsintensiteit en belichtingsduur) (Kool, 2019a). Hoewel een dergelijke indelingsmethode mogelijk is, zitten er ook nadelen aan, met name ten aanzien van de uitvoerbaarheid en handhaafbaarheid. Ten eerste is de benodigde informatie niet volledig beschikbaar binnen de huidige monitoring van energie(gerelateerde) data op de On the Way to PlanetProof-bedrijven. Daarnaast moeten bepaalde aannames worden gedaan om tot een normering voor $\mathrm{CO}_{2}$-emissie te komen. Belangrijk nadeel is dat bepaalde variabelen, zoals aantal uur belichting en belichtingsintensiteit, in de praktijk moeilijk te meten en te borgen zijn. Hiermee lijkt dit systeem voorbij te schieten aan een belangrijk uitgangspunt van SMK, namelijk dat het systeem eenvoudig uitvoerbaar en controleerbaar dient te zijn.

4 www. kasalsenergiebron.nl 


\subsection{Aanbevelingen}

\section{Inleiding}

De studie laat zien dat het netto-elektriciteitsverbruik en het netto-warmteverbruik op de Informatienetbedrijven in de jaren 2015-2017, beide uitgedrukt in kWh per $\mathrm{m}^{2}$ per jaar per bedrijf, de meest belangrijke en significante factoren zijn voor de omvang van de $\mathrm{CO}_{2}$-emissie voor bedrijven met bedekte teelt, in combinatie met de mate waarin deze bronnen van fossiele oorsprong zijn. De andere factoren voegen daar weinig meer aan toe.

\section{Opname inkoop van externe $\mathrm{CO}_{2}$-emissie}

$\mathrm{Bij}$ de huidige $\mathrm{CO}_{2}$-emissiebepaling is de inkoop van extern $\mathrm{CO}_{2}$ weliswaar meegenomen in het raamwerk ter bepaling van de $\mathrm{CO}_{2}$-emissie, maar niet meegeteld, omdat dit nog niet door SMK is besloten. Extern $\mathrm{CO}_{2}$ is niet in de rekenmodule voor broeikasgasemissie opgenomen, maar het verdient wel aanbeveling om dat overwegen. Indien extern $\mathrm{CO}_{2}$ wordt meegenomen in de rekenmodule, wordt ook aanbevolen de $\mathrm{CO}_{2}$-emissie verbonden aan het transporteren en comprimeren van $\mathrm{CO}_{2}$ daarin te betrekken.

\section{Voorstellen voor indelingscategorieën}

Op basis van de analyse van het energieverbruik, de energiegerelateerde teelt- en bedrijfskenmerken en de $\mathrm{CO}_{2}$-emissie zijn de volgende indelingscategorieën te noemen:

- Indeling in gekozen grootteklassen op basis van de totale omvang van de $\mathrm{CO}_{2}$-emissie binnen de bedekte teelten in Nederland:

- Klassen op basis van frequentieverdeling

- Indeling in kwartielen of kwintielen op basis van de omvang van de $\mathrm{CO}_{2}$-emissie en de bijbehorende indeling in geschatte indelingsklasse van de $\mathrm{CO}_{2}$-emissie binnen de bedekte teelten in Nederland:

- Bij de kwartielindeling: '0-25, 25-60, 60-105 en meer dan 105 kg $\mathrm{CO}_{2}$-equivalenten per $\mathrm{m}^{2}$ per jaar per bedrijf';

- Bij de kwintielindeling: '0-20, 20-45, 45-70, 70-110 en meer dan 110 kg CO -equivalenten per m² per jaar per bedrijf'.

- Indeling in kwadranten of klassen op basis van de $\mathrm{CO}_{2}$-emissie en haar bestanddelen en de daarbij behorende geschatte indelingsklassen:

- Bij indeling in vier klassen: '0-25, 25-50, 50-125 en >125 kg CO2-equivalenten per m² per jaar per bedrijf'.

- Indeling op basis van de regressievergelijking met het netto-elektriciteitsverbruik en het nettowarmteverbruik als de enige twee, maar meest significante verklarende variabelen. In dit geval ligt de grenswaarde voor $\mathrm{CO}_{2}$-emissie waaraan minimaal $50 \%$ van de On the Way to PlanetProofbedrijven moet voldoen op circa $25 \mathrm{~kg} \mathrm{CO}$-equivalenten per $\mathrm{m}^{2}$ per jaar per bedrijf. Voor de $25 \%$ meest duurzame bedrijven met een $\mathrm{CO}_{2}$-emissie van minder dan circa $1 \mathrm{~kg} \mathrm{CO}$-equivalenten per $\mathrm{m}^{2}$ per jaar per bedrijf kan worden besloten om geen aanvullende maatregelen te vereisen gedurende een door SMK nader te bepalen periode (in jaren).

- Geen indeling, maar een uniforme prestatie voor $\mathrm{CO}_{2}$-emissiereductie per jaar, bijvoorbeeld $2 \%$, voor alle SMK-bedrijven. Dit kan per jaar worden vereist, maar ook over meerdere jaren om aan te sluiten op het investeringsritme van bedrijven en de ontwikkelingen op energiegebied.

- In het algemeen beschouwd is de indeling van bedrijven op basis van een prestatie-eis het eenvoudigst, omdat deze indeling uitgaat van de beschikbare energiedata op de On the Way to PlanetProof-bedrijven en deze data het makkelijkst te controleren zijn. Bovendien kan de On the Way to PlanetProof-bedrijven flexibiliteit worden geboden door de prestatie-eis te cumuleren over meerdere jaren om aan te sluiten op het individuele investeringsritme.

OPMERKING: de grenswaarden zijn gebaseerd op de Informatienetbedrijven. Voor de On the Way to PlanetProof-bedrijven moeten de grenswaarden worden bepaald op basis van de beschikbare energiedata binnen SMK.

- Het voorstel is om bij indelingen gebaseerd op grenswaarden voor absolute $\mathrm{CO}_{2}$-emissies elke twee of drie jaar een herijking van de geselecteerde indelingscategorie uit te voeren. 


\section{Literatuur en websites}

\section{Referenties}

BIN-cijfers, 2019. Cijfers over de financiële en technische positie van glastuinbouwbedrijven in 2015, 2016 en 2017. Wageningen Economic Research, Den Haag.

BSI, 2011. PAS 2050:2011; Specification for the assessment of the life cycle greenhouse gas emissions of goods and services. ICS code: 13.310; 91.190. London, United Kingdom.

BSI, 2011. Draft PAS 2050-1: 2011; Assessment of life cycle greenhouse gas emissions Supplementary requirements for the application of PAS 2050 to horticultural products. Draft PAS 2050-1 version 7 originated 2011-10-07 - Document number 14031-022-017. London, United Kingdom.

Kool, Anton, 2019. Concept normeringsclassificatie broeikasgasemissie voor bedekte teelten binnen het certificatieschema 'On the Way to PlanetProof'. Notitie Kool Analyse \& Advies, 14 juni 2019.

Kool, A., 2019. Emissiefactoren broeikasgassen in $\mathrm{kg} \mathrm{CO}_{2}$ equivalenten. Excel-document. Kool Analyse \& Advies.

Raaphorst, 2019 Kwantitatieve Informatie voor de Glastuinbouw 2019. Wageningen University \& Research, Businessunit Glastuinbouw.

Van der Velden, Nico en Pepijn Smit, 2018. Energiemonitor van de Nederlandse glastuinbouw 2017. Wageningen, Wageningen Economic Research, Rapport 2018-109. 60 blz.

SMK, 2018. Rekentool broeikasgasemissies bedekte teelten. Kool Analyse \& Advies. Gouda. Beschikbaar via:

https://www. planetproof.eu/675/m/planetproofcertificeren/download.html?downloadId=298\&dow nloadUrl=https://www.smk.nl/Public/PlanetProof_documenten/PP2018/DEFBroeikasgasmodule15 mei2018beveiligd.xlsm\&downloadName=Rekenmodule+broeikasgasemissie + open+en+bedekte+t eelt+(inclusief+handleiding)-Versie +2

Scholten, Jasper \& Hans Blonk. 2011. Industrial produced CO2 used within horticulture production systems. Note, Version: 0.2. Blonk Environmental Consultants / Blonk Milieu Advies, pp. 5.

Vermeulen, P. 2019. Bepaling opname $\mathrm{CO}_{2}$ door verschillende gewassen. Persoonlijke info.

\section{Websites}

www.agrimatie.nl

www.wur.euphoros.nl

www.kasalsenergiebron.nl 


\section{Bijlage 1 Toelichting en achtergrond rekenmodule voor broeikasgasemissie ${ }^{(c)}$}

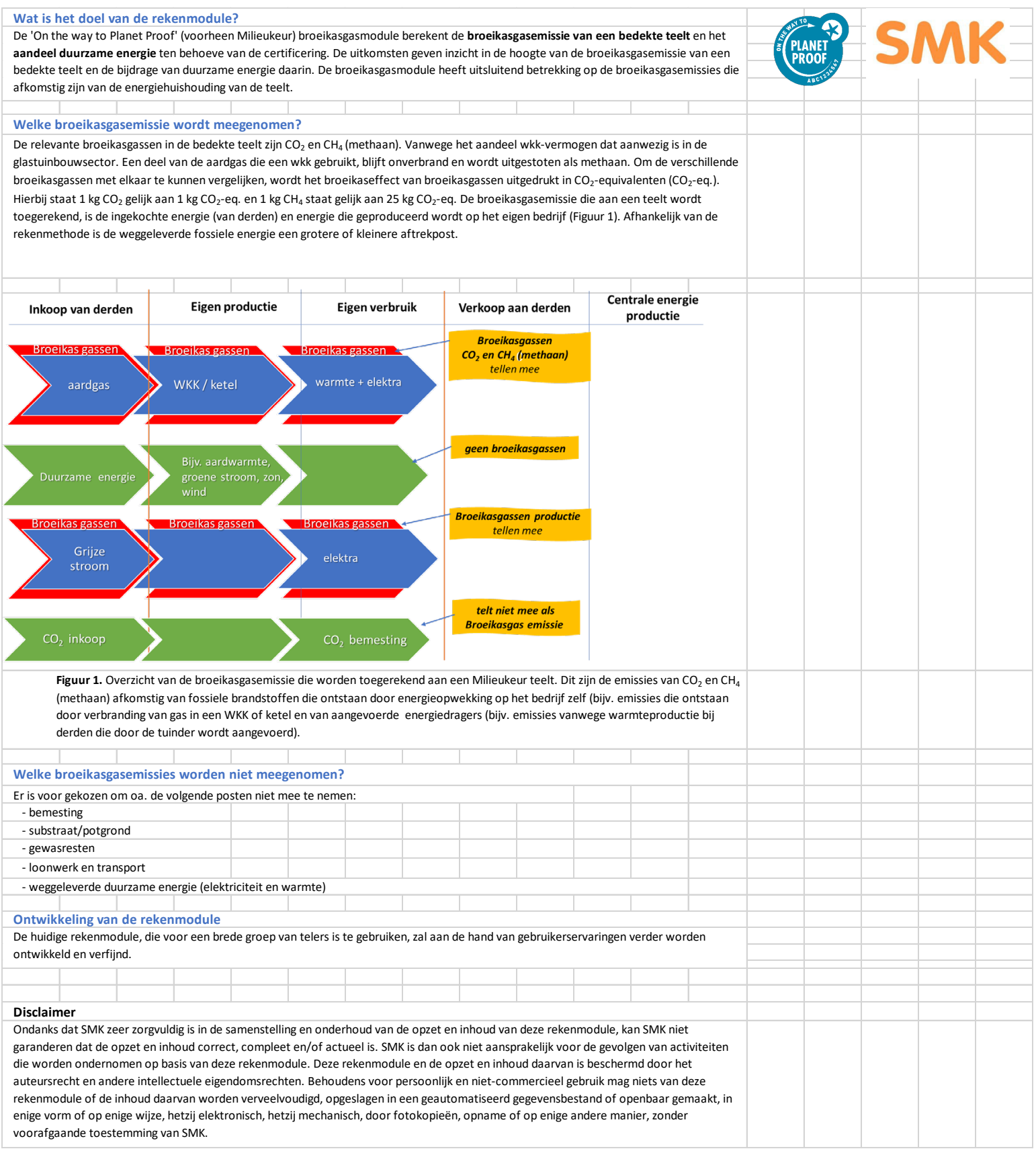




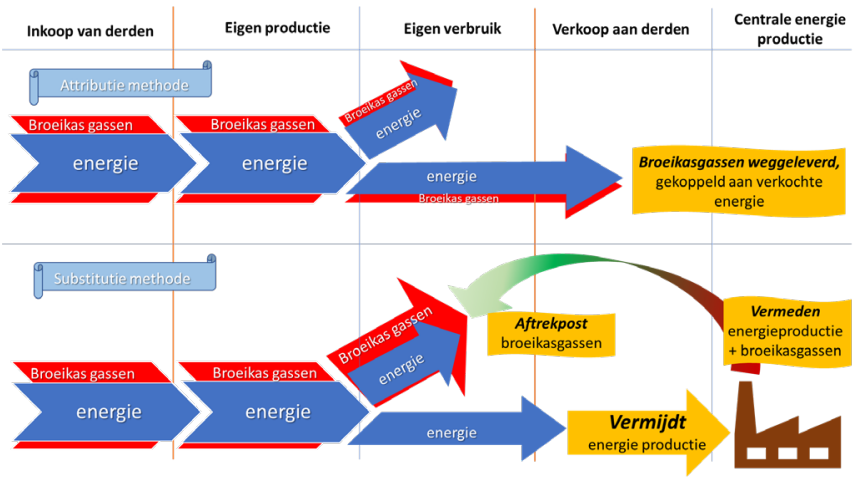

Figuur 2. De wijze waarop de attributie en substitutiemethode omgaan met weglevering van energie in relatie tot correctie van de broeikasgasemissies.

1. Substitutie methode (weglevering naar het net is een grote aftrekpost). In de substitutie methode is het uitgangspunt dat weggeleverde energie aan het elektriciteitsnet, energieopwekking ergens anders vermijdt (bv. elektriciteitscentrale). De geproduceerde broeikasgassen van het aandeel weggeleverde energie (elektra en/of warmte) wordt op basis daarvan van de totale broeikasgasemissie afgetrokken. Dit betekent dat er een correctie plaatsvindt op de hoeveelheid weggeleverde energie op basis van één standaard waarde voor centrale energieopwekking (elektriciteit en warmte). De substitutie methode wordt veel toegepast om op sectorniveau de voor centrale energieopwekking (elektricite

2. Attributie methode (weglevering naar het net is een beperkte aftrekpost; teruggebracht in verhouding tot eigen energie productie). In de attributie methode (Figuur 3 en 4 ) is het uitgangspunt dat er voor weggeleverde energie wordt gecorrigeerd op basis va de efficiëntie van de eigen energieproductie. De broeikasgasemissie van de energieproductie (elektra en/of warmte) op het eigen bedrij wordt berekend en bij weglevering van die energie, wordt op basis van die efficiëntie de totale broeikasgasemissie gecorrigeerd. Een belangrijk verschil met de substitutie methode is dat met de attributie methode verschillen tussen bedrijven op teeltniveau beter tot hun recht komen.

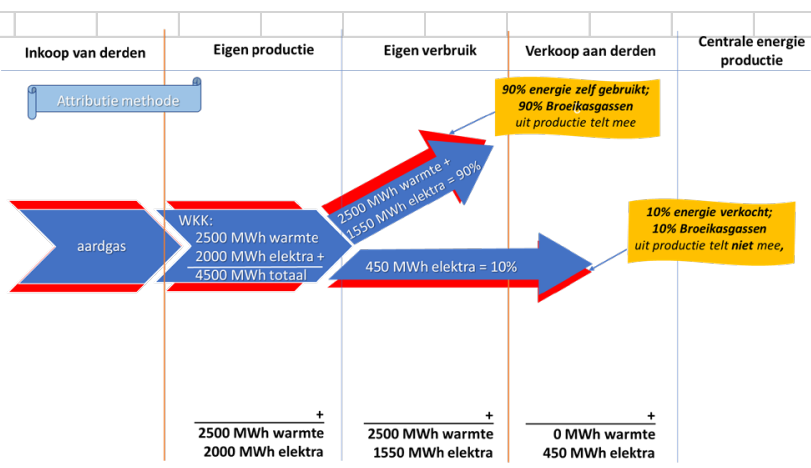

Figuur 3. Voorbeeld van de broeikasgasemissie berekening via de attributie methode bij een bedrijf met een WKK. Hierbij vind een correctie plaats op de broeikasgasemissies bij levering van elektriciteit a an derden die op het eigen bedrij via een WKK is opgewekt. In het voorbeeld is een getallenvoorbeeld uitgewerkt ter illustratie waarbij $2500 \mathrm{MWh}$ warmte en $2000 \mathrm{MWh}$ elektra met een WKK wordt opgewekt. Daarbij ontstaat (bruto) 1 miljoen kg CO2 eq. aan broeikasgasemissies. Van de $2000 \mathrm{MWh}$ elektra wordt bv. $450 \mathrm{MWh}$ elektra geleverd aan een derde. Volgens de berekening komt de correctiefactor, $C$ dan uit op $10 \%$ van de totaal opgewekte energie: $450 /(2500+2000)$. Bij de netto berekening wordt de correctiefactor in mindering gebracht van de bruto broeikasgasemissies: $1.000 .000-100.000=900.000 \mathrm{~kg} \mathrm{CO}$-eq.

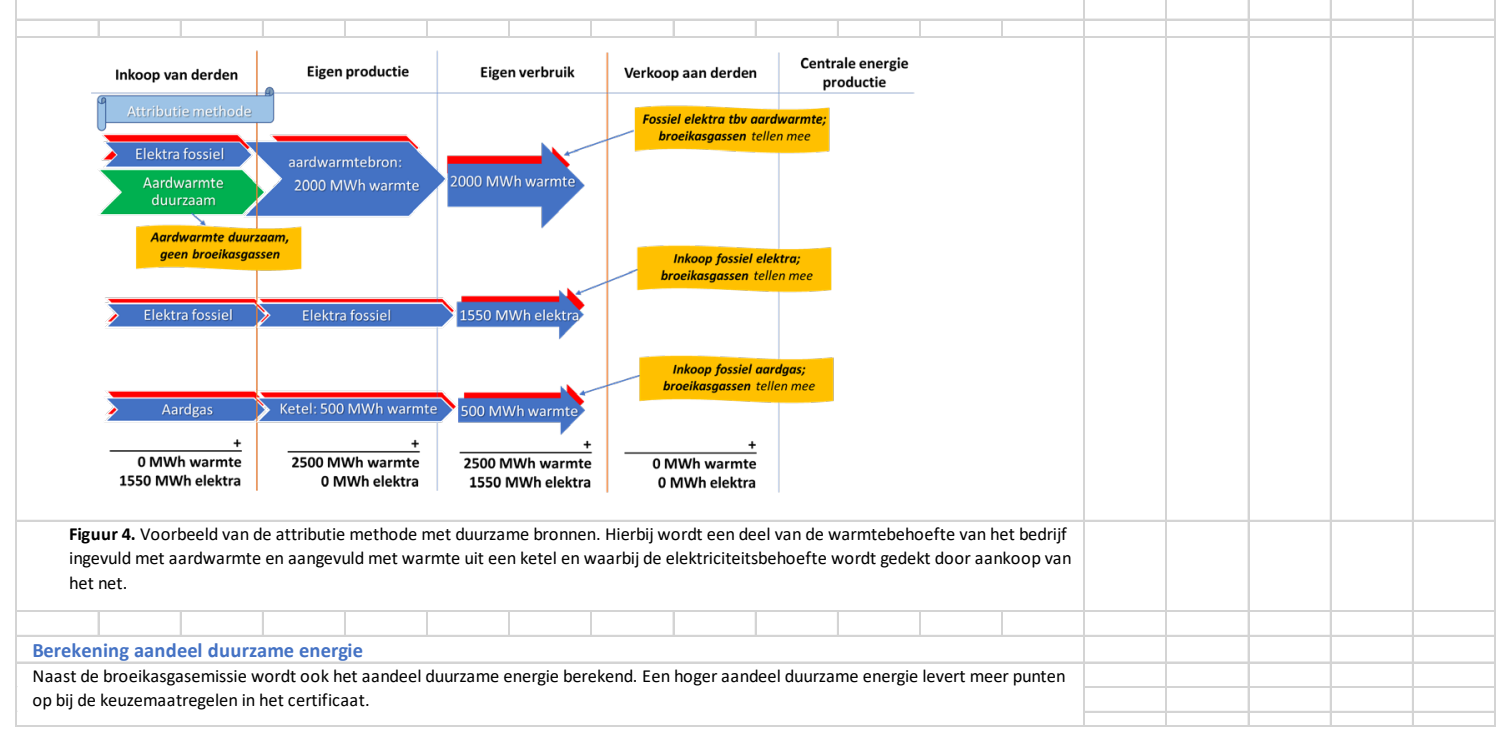




\section{Bijlage 2 Toelichting verschillende methodieken om de broeikasgasemissie op glastuinbouwbedrijven te kwantificeren}

Er zijn drie methoden die worden gebruikt ten behoeve van verschillende doeleinden:

- SMK-attributie: SMK past deze methode toe in de certificatieschema's 'On the Way to PlanetProof' en 'Groen Label Kas'.

- SMK-substitutie: SMK gebruikt deze methode in het certificatieschema 'On the Way to PlanetProof'.

- IPCC: deze Methode wordt toegepast bij de handel in $\mathrm{CO}_{2}$-emissierechten. Bedrijven die verplicht zijn om hieraan deel te nemen, dienen volgens deze systematiek hun emissies te registreren.

Deze drie methoden verschillen van elkaar op basis van:

- afbakening: welke emissiebronnen in de keten wel en niet worden meegenomen;

- afbakening: welke broeikasgassen in beschouwing worden genomen;

- allocatie: hoe wordt omgegaan met coproductie, met andere woorden hoe de emissies worden verdeeld van een proces waarbij meerdere producten worden geproduceerd. Bijvoorbeeld een wkk: hoe worden de emissies van gasverbranding in de wkk verdeeld over de warmte en elektra die worden geproduceerd?

In onderstaande tabel zijn de verschillende methodes op tien criteria vergeleken. 


\section{Attributiemethodiek SMK Substitutiemethodiek SMK IPCC (EU-ETS)}

\section{Afbakening}

Emissiebronnen die

meegewogen worden
Gebruik brandstoffen en

aanvoer elektriciteit en warmte
Gebruik brandstoffen en

aanvoer elektriciteit en warmte
Gebruik brandstoffen (voor glastuinbouw alleen gas) exclusief aanvoer elektriciteit en warmte

\begin{tabular}{|c|c|c|c|}
\hline Klimaatemissies & $\mathrm{CO}_{2}$ en $\mathrm{CH}_{4}$ (methaan) & $\mathrm{CO}_{2}$ en $\mathrm{CH}_{4}$ (methaan) & $\mathrm{CO}_{2}$ \\
\hline Bedrijf vs. keten & $\begin{array}{l}\text { Emissies op bedrijf en emissies } \\
\text { vanwege productie van } \\
\text { ingekochte energie (zgn. } \\
\text { scope } 2 \text { ) }\end{array}$ & $\begin{array}{l}\text { Emissies op bedrijf en emissies } \\
\text { vanwege productie van } \\
\text { ingekochte energie (zgn. } \\
\text { scope } 2 \text { ) }\end{array}$ & $\begin{array}{l}\text { Emissies op bedrijf } \\
\text { (zgn. scope } 1 \text { ) }\end{array}$ \\
\hline \multicolumn{4}{|l|}{ Wegleveren energie } \\
\hline \multicolumn{4}{|l|}{ Toepasbaarheid } \\
\hline Doel methode & $\begin{array}{l}\text { Broeikasgasemissies op } \\
\text { bedrijfs- en teeltniveau } \\
\text { monitoren }\end{array}$ & $\begin{array}{l}\text { Broeikasgasemissies op } \\
\text { bedrijfs- en teeltniveau } \\
\text { monitoren }\end{array}$ & $\begin{array}{l}\text { Effectuering Europees beleid } \\
\text { om } \mathrm{CO}_{2} \text {-reductie bij grote } \\
\text { bedrijven te realiseren }\end{array}$ \\
\hline $\begin{array}{l}\text { Resultaat afhankelijk } \\
\text { van prestaties in } \\
\text { andere sectoren? }\end{array}$ & Nee & $\mathrm{Ja}$ & Nee \\
\hline $\begin{array}{l}\text { Internationaal } \\
\text { vergelijkbaar? }\end{array}$ & $\mathrm{Ja}$ & Nee & Nee \\
\hline \multicolumn{4}{|l|}{ Effectiviteit } \\
\hline $\begin{array}{l}\text { Stimulering reductie } \\
\text { fossiel energiegebruik }\end{array}$ & $\begin{array}{l}\text { Directe sturing door focus op } \\
\text { emissies die uitsluitend } \\
\text { gerelateerd zijn aan eigen } \\
\text { bedrijf/teelt }\end{array}$ & $\begin{array}{l}\text { Deels sturing op reductie van } \\
\text { het totaalverbruik en deels } \\
\text { sturing op het zoveel mogelijk } \\
\text { vervangen van centrale } \\
\text { energieproductie. Dit laatste is } \\
\text { echter fossiele energie } \\
\text { vervangen door iets efficiënter } \\
\text { omgezette fossiele energie }\end{array}$ & $\begin{array}{l}\text { Alleen sturing op aanvoer van } \\
\text { brandstoffen. Geen sturing op } \\
\text { aanvoer van elektriciteit en } \\
\text { warmte van buiten het bedrijf }\end{array}$ \\
\hline $\begin{array}{l}\text { Stimulering niet- } \\
\text { fossiele innovaties, } \\
\text { bijv. aardwarmte, } \\
\text { t.o.v. fossiel }\end{array}$ & $\begin{array}{l}\text { Niet-fossiele energieopwekking } \\
\text { wordt altijd gestimuleerd t.o.v. } \\
\text { fossiel }\end{array}$ & $\begin{array}{l}\text { Niet altijd, fossiel } \\
\text { energiegebruik kan gunstig } \\
\text { naar voren komen zolang dit } \\
\text { efficiënter is dan de vermeden } \\
\text { (fossiele) energieopwekking }\end{array}$ & $\begin{array}{l}\text { Alleen indien dit effect heeft op } \\
\text { de aanvoer van brandstoffen }\end{array}$ \\
\hline
\end{tabular}




\section{Bijlage $3 \quad \mathrm{CO}_{2}$-emissie $\left(\mathrm{kg} \mathrm{CO}_{2}-\right.$ equivalenten per $\mathrm{m}^{2}$ per jaar) en haar bestanddelen per bedrijf in 2015 en 2016}

$\mathrm{kg} \mathrm{CO}_{2}$ per $\mathrm{m}^{2}$ eq naar veroorzaker 2016

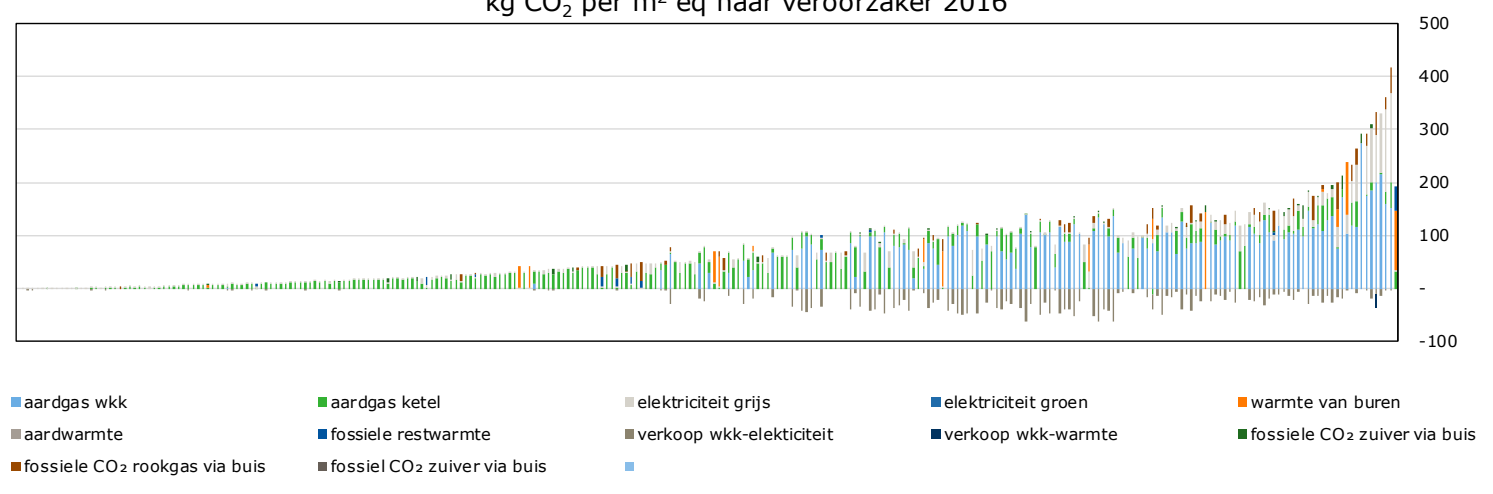

$\mathrm{kg} \mathrm{CO}$ per $\mathrm{m}^{2}$ eq naar veroorzaker 2015

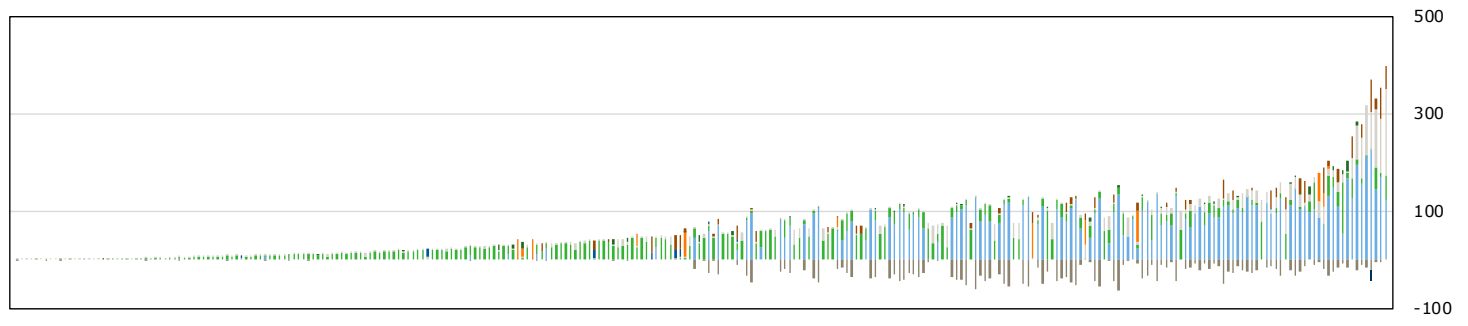

\begin{tabular}{|c|c|c|c|c|}
\hline = aardgas wkk & - aardgas ketel & $\begin{array}{l}\text { elektriciteit grijs } \\
\text { verkoop wkk-elekticiteit }\end{array}$ & $\begin{array}{l}\text { - elektriciteit groen } \\
\text { - verkoop wkk-warmte }\end{array}$ & $\begin{array}{l}\text { warmte van buren } \\
\text { fossiele } \mathrm{CO}_{2} \text { zuiver via buis }\end{array}$ \\
\hline
\end{tabular}


Wageningen Economic Research Postbus 29703

2502 LS Den Haag

T 0703358330

Ecommunications.ssg@wur.nl

www.wur.nl/economic-research

Wageningen Economic Research RAPPORT

2020-012
De missie van Wageningen University \& Research is 'To explore the potential of nature to improve the quality of life'. Binnen Wageningen University \& Research bundelen Wageningen University en gespecialiseerde onderzoeksinstituten van Stichting Wageningen Research hun krachten om bij te dragen aan de oplossing van belangrijke vragen in het domein van gezonde voeding en leefomgeving. Met ongeveer 30 vestigingen, 5.000 medewerkers en 10.000 studenten behoort Wageningen University \& Research wereldwijd tot de aansprekende kennisinstellingen binnen haar domein. De integrale benadering van de vraagstukken en de samenwerking tussen verschillende disciplines vormen het hart van de unieke Wageningen aanpak. 



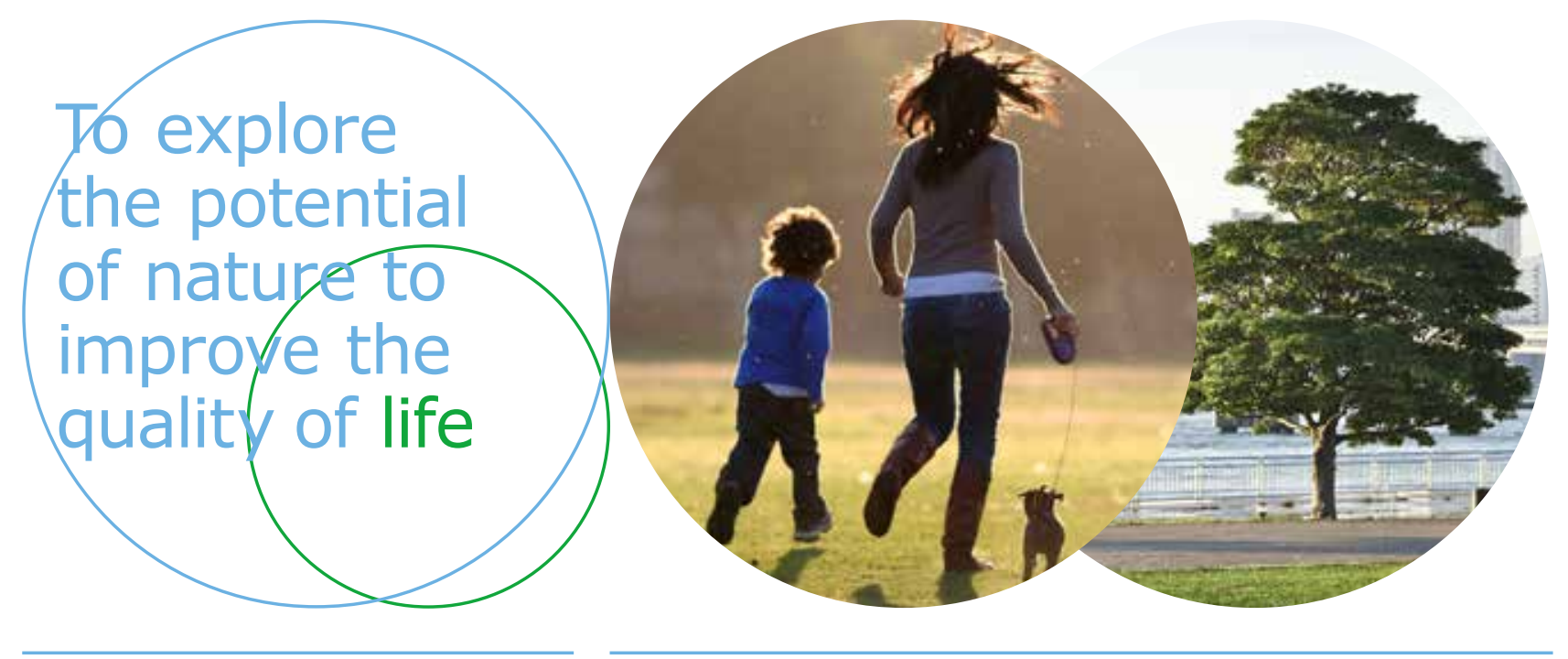

Wageningen Economic Research Postbus 29703

2502 LS Den Haag

E communications.ssg@wur.nl

$\mathrm{T}+31(0) 703358330$

www.wur.nl/economic-research

Rapport 2019-102

ISBN 978-94-6395-255-2
De missie van Wageningen University \& Research is 'To explore the potential of nature to improve the quality of life'. Binnen Wageningen University \& Research bundelen Wageningen University en gespecialiseerde onderzoeksinstituten van Stichting Wageningen Research hun krachten om bij te dragen aan de oplossing van belangrijke vragen in het domein van gezonde voeding en leefomgeving. Met ongeveer 30 vestigingen, 5.000 medewerkers en 10.000 studenten behoort Wageningen University \& Research wereldwijd tot de aansprekende kennisinstellingen binnen haar domein. De integrale benadering van de vraagstukken en de samenwerking tussen verschillende disciplines vormen het hart van de unieke Wageningen aanpak. 